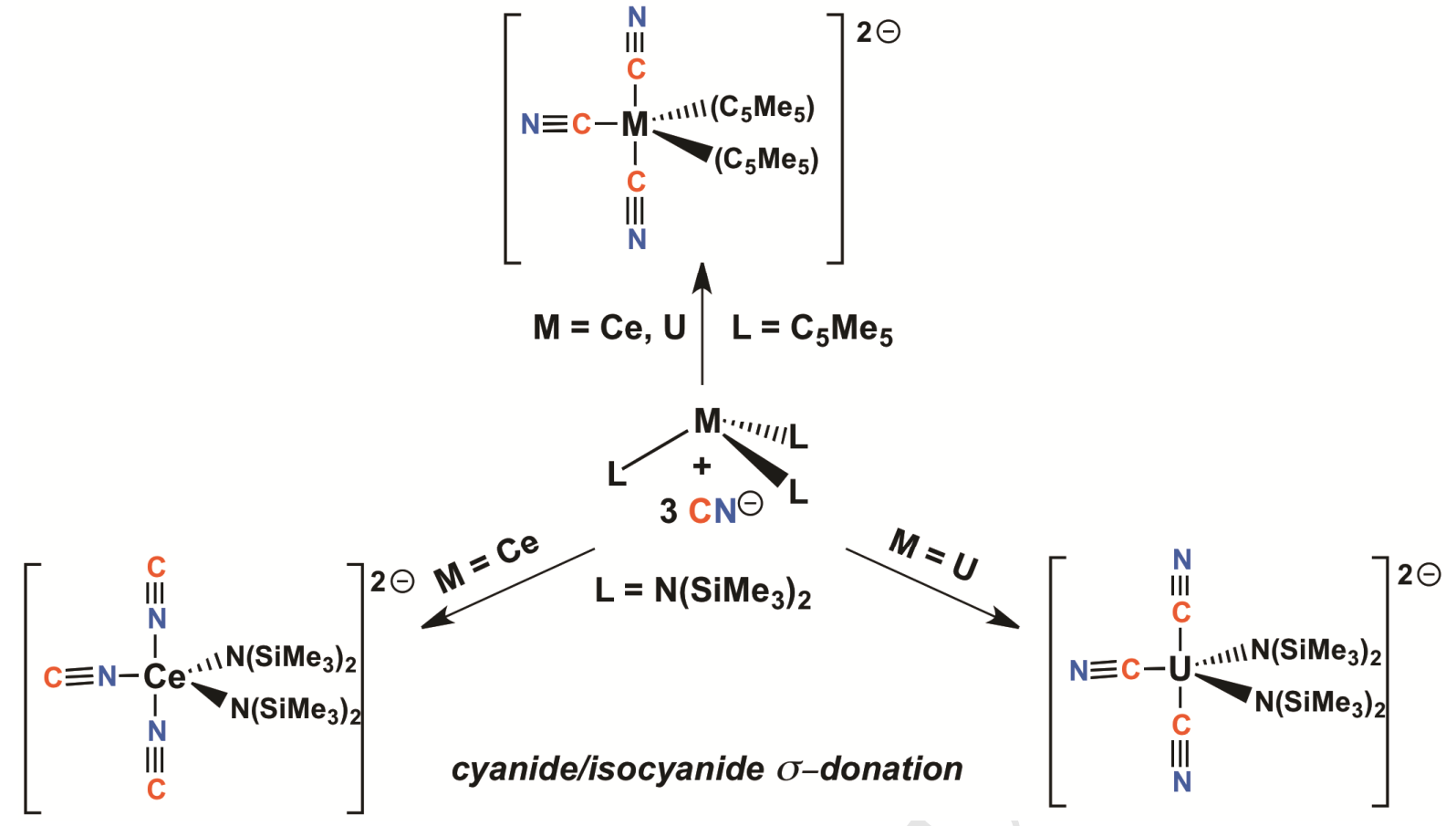




\section{Cyanide linkage isomerism in cerium(III) and uranium(III) complexes. A relativistic DFT study}

Yamina Bouzidi ${ }^{\mathrm{a}, \mathrm{b}}$, Lotfi Belkhiri ${ }^{\mathrm{b},{ }^{*}}$, Michel Ephritikhine ${ }^{\mathrm{c}}$, Jean-François Halet ${ }^{\mathrm{d}, *}$, and Abdou Boucekkine ${ }^{\mathrm{d}, *}$

${ }^{a}$ Département de Chimie, Université de Batna 1, 05000 Batna, Algeria

${ }^{\mathrm{b}}$ URCHEMS, Département de Chimie, Université des Frères Mentouri Constantine 1, 25017 Constantine, Algeria

${ }^{\mathrm{c}}$ NIMBE, CEA, CNRS, Université Paris-Saclay,CEA Saclay, 91191 Gif-sur-Yvette, France

${ }^{\mathrm{d}}$ Institut des Sciences Chimiques de Rennes, UMR 6226 CNRS - Université de Rennes 1, 35042 Rennes Cedex, France

\section{ABSTRACT}

The chemistry of cyanide complexes of the $f$-elements has witnessed significant recent advances, showing in particular the remarkable ability of the cyanide ligand to stabilize uranium compounds in their +3 to +6 oxidation states and its capacity to adopt two distinct ligation modes, namely cyanide $\mathrm{M}-\mathrm{CN}$ or isocyanide $\mathrm{M}-\mathrm{NC}$, towards trivalent $\mathrm{f}$-ions. Here, we have theoretically investigated the tris(cyanide) complexes $\left[\mathrm{ML}_{2} \mathrm{X}_{3}\right]^{2-}\left(\mathrm{M}=\mathrm{Ce}^{3+}, \mathrm{U}^{3+} ; \mathrm{L}=\right.$ $\left.\mathrm{C}_{5} \mathrm{H}_{4} \mathrm{Me}, \mathrm{N}\left(\mathrm{SiMe}_{3}\right)_{2} ; \mathrm{X}=\mathrm{CN}, \mathrm{NC}\right)$, using relativistic DFT computations, focusing on cyanide $\left(\mathrm{CN}^{-}\right)$and isocyanide $\left(\mathrm{NC}^{-}\right)$coordination competition and differences between their electronic structures. X-ray crystal data reveal distinct coordination modes of the $\mathrm{CN}$ ligand towards uranium and cerium metal centers. Interestingly, in the case of the cerium complexes, and contrarily to the uranium ones, the coordination mode of the cyanide ligand depends on the co-ligand $\mathrm{L}$ attached to the metal. The observed coordination in these tris(cyanide) complexes is driven by the binding energies of the $\mathrm{CN}^{-} / \mathrm{NC}^{-}$ligands to the metals. The solvent is shown to play a determining role for the chosen coordination. The developed methodology can help to confirm the cyanide or isocyanide coordination mode when X-ray crystal data are not conclusive or to predict the configuration of a complex to be synthesized. Another application is in the field of lanthanide(III)/actinide(III) differentiation.

Keywords: Cyanide, $f$-complexes, Ln(III)/An(III) differentiation, CN-coordination isomerism, DFT calculations, solvation effects

* Corresponding authors. E-mail address: lotfi.belkhiri@umc.edu.dz (L. Belkhiri), halet@univ-rennes1.fr (J.-F. Halet), abdou.boucekkine@univ-rennes1.fr (A. Boucekkine)

Dedicated to our good friend and colleague John Gladysz on the occasion of his $65^{\text {th }}$ Birthday. 


\section{Introduction}

Since the first synthesis of $f$-element cyanide complexes in the early seventies [1], the cyanide $\mathrm{CN}^{-}$ligand has gained a prominent position in both $d$ - and $f$-coordination chemistry mainly because of its strong coordinating ability, its capacity to stabilize a wide range of oxidation states and to adopt different ligation modes, thus giving a rich variety of homo and heteropolynuclear compounds with interesting stereochemistry and properties [2]. This is attributed to the strong $\sigma$-donor character of the cyanide and isocyanide ligands, via donation from either the C-localized orbital of $\mathrm{CN}^{-}$(carbon lone pair) or the $\mathrm{N}$-localized one of $\mathrm{NC}^{-}$ with nitrogen major character $[2 b]$. Therefore, this field is currently attracting attention in various domains, especially in $d$-metal coordination chemistry, with applications in biology and materials science, exemplified with the discovery of molecular-based assemblies with cyanide bridges, giving magnetic materials and providing significant insights into magnetostructural correlations [3].

However, $f$-element cyanide complexes have received much less attention, while the lanthanide and actinide chemistry experienced a spectacular development during the last decades [4,5]. Indeed, the different binding modes of cyanide or isocyanide $\mathrm{CN}^{-} / \mathrm{NC}^{-}$anions towards trivalent $f$-ions was reported recently, revealing a potential application in lanthanide(III)/actinide(III) differentiation [5a,6,7]. Thus, a number of mono and polycyanide complexes of cerium and uranium have been isolated and crystallographically characterized, starting from the metallocene complexes $\left[\mathrm{M}\left(\mathrm{Cp}^{*}\right)_{2}(\mathrm{CN})_{3}\right]^{2-}\left(\mathrm{M}=\mathrm{Ce}, \mathrm{U} ; \mathrm{Cp} *=\mathrm{C}_{5} \mathrm{Me}_{5}\right)$ which were the first trivalent molecular polycyanide compounds of an $f$-element to have been structurally characterized [2b], followed by the successive syntheses of the mononuclear $\left[\mathrm{MN}_{3}(\mathrm{CN})\right]^{-},\left[\mathrm{MN}_{3}(\mathrm{CN})_{2}\right]^{2-},\left[\mathrm{MN}_{2}{ }_{2}(\mathrm{CN})_{3}\right]^{2-}$ and cyanido-bridged dinuclear $\left[\left(\mathrm{MN}_{3}\right)_{2}(\mu-\right.$ $\mathrm{CN})]^{-}\left(\mathrm{M}=\mathrm{Ce}, \mathrm{U} ; \mathrm{N}^{*}=\mathrm{N}\left(\mathrm{SiMe}_{3}\right)_{2}\right)$ anionic compounds [2a]. It is worth noting that the bis(silylamide) ligand $\mathrm{N}^{*}$ seems to play a crucial role in stabilizing these polycyanide complexes. It was observed in these latter species that the cerium(III) complexes are 
isomorphous but not isostructural to their uranium(III) counterparts because of the distinct cyanide or isocyanide $\mathrm{M}-\mathrm{CN} / \mathrm{NC}$ linkage in the crystal. This striking difference between the cyanide and isocyanide ligation modes in the uranium and cerium compounds was tentatively explained by the fact that the U(III) ion is softer than the Ce(III) ion in the hard and soft (Lewis) acids and bases (HSAB) classification and will have a greater affinity for the softer carbon end of the $\mathrm{CN}$ ligand $[2 \mathrm{~b}]$.

Synergetic studies at both experimental and theoretical levels were carried out investigating the fundamental chemical differences between the $4 f$ elements, lanthanides (Ln), and the $5 f$ elements, actinides (An), in this field [8-10]. In particular, the coordination competition between cyanide $\left(\mathrm{CN}^{-}\right)$and isocyanide $\left(\mathrm{NC}^{-}\right)$has been studied theoretically in the case of uranyl derivatives [2b, 8, 9], and also for pentacyanide and isocyanide complexes of (IV), U(V) and U(VI) of general formula $\left[\mathrm{X}_{2} \mathrm{U}(\mathrm{CN})_{5}\right]^{\mathrm{q}-}\left(\mathrm{X}=\mathrm{O}, \mathrm{Cp}=\mathrm{C}_{5} \mathrm{H}_{5}\right)[2 \mathrm{~b}, 8]$. Indeed, it has been shown that cyanide coordination is preferred, although the isocyanide form is also a stable configuration [8]. Two structurally stable structures have been predicted with cyanide linkage mode for the $\left[\mathrm{UO}_{2}(\mathrm{CN})_{5}\right]^{4-}$ and $\left[\mathrm{Cp}_{2} \mathrm{U}(\mathrm{CN})_{5}\right]^{-}$uranyl and $\mathrm{Cp}$-type systems.

In this context, we reported recently a theoretical study on the preferential ligation modes of the cyanide and isocyanide ligands in the $\mathrm{Ce}(\mathrm{III}) / \mathrm{U}(\mathrm{III})$ bis(cyanide) $\left[\mathrm{MN}_{3}(\mathrm{CN})_{2}\right]^{2-}$ complexes [10a]. Based on X-ray data and computational DFT analysis, the preference in $\mathrm{M}-\mathrm{CN} / \mathrm{NC}$ ligation modes has been rationalized by considering the electronic structures and the ligand-to-metal binding energies. Specifically, it has been found that the stronger $\sigma$ donating ability of the cyanide ligand toward uranium and not cerium is related to the better energy matching between $6 d / 5 f$ uranium metal and ligand orbitals [11]. The same observation has been made in the case of U(III) and U(IV) bis(silylamide) mono and bis(cyanide) complexes $\left[\mathrm{UN}_{3}^{*} \mathrm{X}\right]^{\mathrm{q}-}$ and $\left[\mathrm{UN}_{3}{ }_{3} \mathrm{X}_{2}\right]^{\mathrm{q}-}(\mathrm{q}=2,1 ; \mathrm{X}=\mathrm{CN}, \mathrm{NC})$, the covalency contribution to the bonding being also at work (orbital mixing) [10b].

Although the cyanide $\mathrm{M}-\mathrm{CN}$ ligation mode is ubiquitous for various uranium complexes in different oxidation states (III-VI) [12], the preference for cyanide or isocyanide coordination could remain controversial for some systems. Indeed, as noted by previous theoretical studies $[8,9]$, controversy still exists about the preference for the $\mathrm{C}$ or $\mathrm{N}$ coordination in the case of uranyl ion derivatives, where the cyanide complexes might be more stable than their isocyanide congeners, noting that the energy difference is only $3.3 \mathrm{kcal}_{\mathrm{mol}}{ }^{-1}$ [9c]. 
In the present study, we have investigated using relativistic density functional theory (DFT), the electronic structures of several analogous tris(cyanide) complexes of cerium(III) and uranium(III), with different cyanide and isocyanide ligation modes. The target systems are the bis(cyclopentadienyl) and bis(silylamide) tris(cyanide) compounds $\left[\mathrm{M}\left(\mathrm{Cp}^{*}\right)_{2}(\mathrm{CN})_{3}\right]^{2-}$ and $\left[\mathrm{MN}_{2}(\mathrm{CN})_{3}\right]^{2-}(\mathrm{M}=\mathrm{Ce}, \mathrm{U})$, which have been synthesized recently and crystallographically characterized [10a]. Unexpected coordination modes have been observed. For the bis(cyclopentadienyl) complexes, the X-ray crystal structures show the unambiguous $\mathrm{M}-\mathrm{C}$ bonding mode of the $\mathrm{CN}$ ion. On the contrary, the observed structures of the bis(silylamide) $\mathrm{Ce}(\mathrm{III})$ and $\mathrm{U}(\mathrm{III})$ complexes exhibit distinct coordination modes of the cyanide $\mathrm{CN}$ ligand, through the $\mathrm{N}$ or $\mathrm{C}$ atom to the $\mathrm{Ce}(\mathrm{III})$ or $\mathrm{U}(\mathrm{III})$ ions, respectively. Our aim is to rationalize these particular coordinations, especially in the context of $\operatorname{Ln}(\mathrm{III}) / \mathrm{An}$ (III) differentiation.

\section{Results and discussion}

"The determining factor (vide infra) leading to the M-CN or M-NC coordination mode is the binding energy between the metal fragment and the CN or NC ligand [10a,b]. As shown below, these binding energies differences between isomers range from $c a .4$ to $14 \mathrm{kcal} / \mathrm{mol}$, except for the $\left[\mathrm{UN}_{2}^{*} \mathrm{X}_{3}\right]^{2-}$ case for which these binding energies differences are much smaller.

\subsection{DFT molecular geometry optimization of the tris(cyanide) complexes}

We consider the actual complexes of general formula $\left[\mathrm{ML}_{2} \mathrm{X}_{3}\right]^{2-}\left(\mathrm{M}=\mathrm{Ce}^{3+} / \mathrm{U}^{3+} ; \mathrm{L}=\right.$ $\mathrm{Cp} * / \mathrm{N}^{*}$ and $\mathrm{X}=\mathrm{CN} / \mathrm{NC}$ ) and their hypothetical isomers. All structures were fully optimized using the BP86 functional coupled to the polarized double- $\zeta$ Slater basis set (DZP) in the framework of the relativistic zeroth-order regular approximation (ZORA). The solvent (THF) was treated using the COSMO solvation model, implemented in the ADF program (see Computational details). As previously stated [13,14], ZORA/BP86/DZP computed geometries of $f$-elements complexes are generally in good agreement with $\mathrm{X}$-ray crystal structures. Computed bond lengths $\mathrm{M}-\mathrm{X}, \mathrm{M}-\mathrm{L}\left(\mathrm{L}=\mathrm{Cp}^{*}\right.$ and $\left.\mathrm{N}^{*}\right)$ and $\mathrm{C}-\mathrm{N} / \mathrm{N}-\mathrm{C}$ of the optimized structures (Fig. 1 and 2) are reported in Table 1 for the actual complexes $\left[\mathrm{MCp}^{*}{ }_{2}(\mathrm{CN})_{3}\right]^{\mathrm{q}-}(\mathrm{M}$ $\left.=\mathrm{Ce}^{3+}, \mathrm{U}^{3+/ 4+} ; \mathrm{q}=2,1\right)(\mathbf{1 a})$ and (1b) (complexes 6 and $\mathbf{5}$ in ref. 2b), and their hypothetical isomers $\left[\mathrm{MCp}_{2}{ }_{2}(\mathrm{NC})_{3}\right]^{\mathrm{q}-}$. The computed parameters for the isocyanide cerium(III) $\left[\mathrm{CeN}_{2}{ }_{2}(\mathrm{NC})_{3}\right]^{2-}(\mathbf{2 a})$ and cyanide uranium(III) $\left[\mathrm{UN}^{*}{ }_{2}(\mathrm{CN})_{3}\right]^{2-}(\mathbf{2} \mathbf{b})$ complexes (respectively 
complexes $\mathbf{4 a}$ and $\mathbf{4 b}$ in reference 10a) and their hypothetical isomers, are also given in Table 1 .
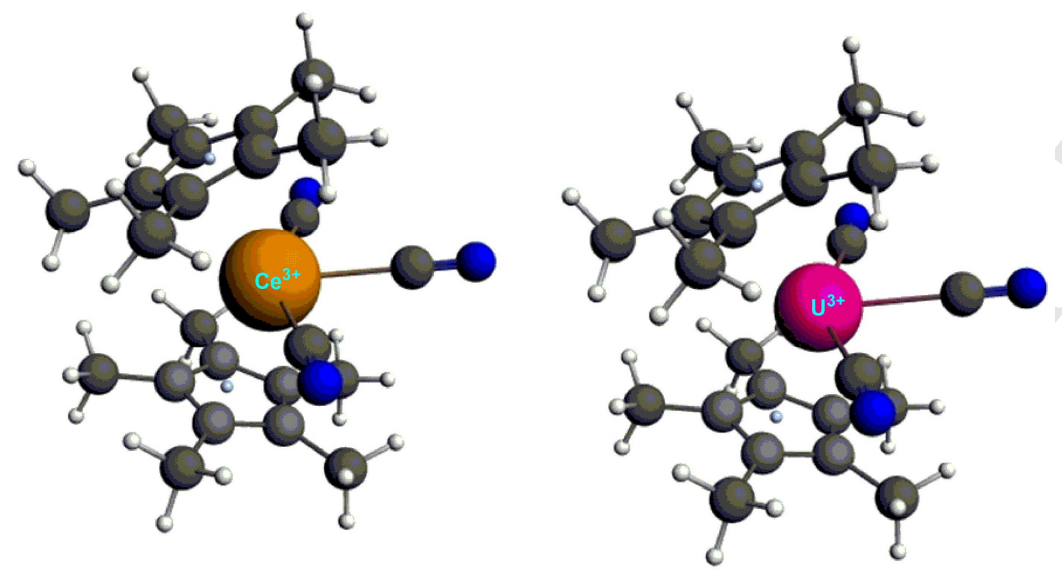

Fig. 1. ZORA/BP86/DZP optimized geometry of the bis(cyclopentadienyl) tris(cyanide) $\left[\mathrm{MCp}_{2}{ }_{2} \mathrm{X}_{3}\right]^{2-}$ complexes $\left(\mathrm{M}=\mathrm{Ce}^{3+}, \mathrm{U}^{3+} ; \mathrm{X}=\mathrm{CN}\right) \mathbf{1 a}$ (left) and $\mathbf{1 b}$ (right). The blue, black, and white spheres are nitrogen, carbon, and hydrogen atoms, respectively.
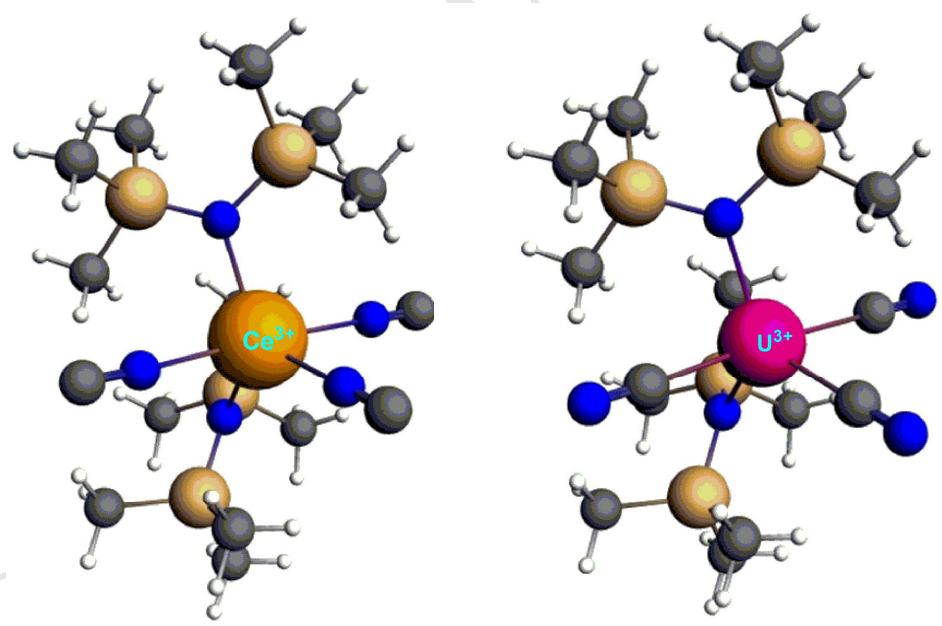

Fig. 2. ZORA/BP86/DZP optimized structures of the bis(silylamide) tris(cyanide/isocyanide) complexes $\left[\mathrm{MN}^{*}{ }_{2} \mathrm{X}_{3}\right]^{2-}$ complexes $\left(\mathrm{M}=\mathrm{Ce}^{3+}, \mathrm{U}^{3+} ; \mathrm{X}=\mathrm{CN}, \mathrm{NC}\right), \mathbf{2 a}$ (left) and $\mathbf{2 b}$ (right). The orange, blue, black, and white spheres are silicon, nitrogen, carbon, and hydrogen atoms, respectively.

The computed geometries of the actual $\left[\mathrm{MCp}_{2}{ }_{2}(\mathrm{CN})_{3}\right]^{2-} \mathrm{Ce}^{\mathrm{IIII}}-\mathrm{CN}$ and $\mathrm{U}^{\mathrm{III} / \mathrm{IV}}-\mathrm{CN}$ compounds are in good agreement with the available X-ray data, noting however a slight discrepancy of $c a .0 .06 \AA$ for the metal-ligand bond distance in the case of the bis(silylamide) $\mathrm{Ce}^{\mathrm{III}}-\mathrm{NC}$ derivtive (Table 1). This good agreement shows once again the reliability of the ZORA/BP86/DZP method in computing molecular $f$-complex geometries. Notably, the 
shortening of the metal-ligand bond distances when going from U(III) to U(IV), in line with uranium ionic radii variation [15], is well predicted by computation.

\section{Table 1}

Relevant optimized averaged metal-ligand bond distances $(\AA)$ at the ZORA/BP86/DZP level and $\mathrm{X}$-Ray data where available (in bold) for the $\left[\mathrm{ML}_{2} \mathrm{X}_{3}\right]^{\mathrm{q}-}$ complexes $\left(\mathrm{M}=\mathrm{Ce}^{3+}, \mathrm{U}^{3+}\right.$ and $\mathrm{U}^{4+} ; \mathrm{X}=\mathrm{CN} / \mathrm{NC} ; \mathrm{L}=\mathrm{Cp} * / \mathrm{N}^{*} ; \mathrm{q}=2,1$ ) in the gas phase and in solution (in italics).

\begin{tabular}{ccccc}
\hline Complex & $\langle\mathrm{M}-\mathrm{C} / \mathrm{N}\rangle$ & $\Delta(\AA)^{\mathrm{a}}$ & $\langle\mathrm{C}-\mathrm{N} / \mathrm{N}-\mathrm{C}\rangle$ & $\langle\mathrm{M}-\mathrm{L}\rangle$ \\
\hline$\left[\mathrm{MCp}^{*}{ }_{2} \mathrm{X}_{3}\right]^{\mathrm{q}-}$ & & & \\
$\mathrm{Ce}^{3+}$ & $2.665 / 2.535$ & & $1.178 / 1.182$ & $2.621 / 2.638$ \\
& $2.655 / 2.546$ & & $1.176 / 1.177$ & $2.586 / 2.583$ \\
& $\mathbf{2 . 6 6 6 / -}$ & & $\mathbf{1 . 1 5 8 / -}$ & $\mathbf{2 . 5 6 2 / -}$ \\
$\mathrm{U}^{3+}$ & $2.612 / 2.492$ & $0.053 / 0.043$ & $1.178 / 1.183$ & $2.571 / 2.560$ \\
& $2.585 / 2.489$ & $0.070 / 0.057$ & $1.177 / 1.180$ & $2.509 / 2.534$ \\
& $\mathbf{2 . 6 4 0 / -}$ & & $\mathbf{1 . 1 5 6 / -}$ & $\mathbf{2 . 5 3 4 / -}$ \\
$\mathrm{U}^{4+}$ & $2.501 / 2.389$ & & $1.175 / 1.185$ & $2.482 / 2.507$ \\
& $2.520 / 2.424$ & & $1.176 / 1.180$ & $2.476 / 2.493$ \\
& $\mathbf{2 . 5 2 0 / -}$ & & $\mathbf{1 . 1 5 8 / -}$ & $\mathbf{2 . 4 4 6 / -}$ \\
\hline $\left.\mathrm{MN}^{*}{ }_{2} \mathrm{X}_{3}\right]^{\mathrm{q}-}$ & & & & \\
$\mathrm{Ce}^{3+}$ & $2.666 / 2.511$ & & $1.176 / 1.183$ & $2.413 / 2.427$ \\
& $2.657 / 2.523$ & & $1.175 / 1.179$ & $2.379 / 2.387$ \\
& $-/ 2.580$ & & $-/ 1.164$ & $-/ 2.390$ \\
$\mathrm{U}^{3+}$ & $2.605 / 2.462$ & $0.061 / 0.049$ & $1.178 / 1.185$ & $2.377 / 2.394 /$ \\
& $2.593 / 2.472$ & $0.064 / 0.051$ & $1.176 / 1.181$ & $2.348 / 2.358$ \\
& $\mathbf{2 . 6 0 0 / -}$ & & $\mathbf{1 . 1 4 8 / -}$ & $\mathbf{2 . 3 3 4 / -}$ \\
& $2.512 / 2.374$ & & $1.175 / 1.186$ & $2.239 / 2.253$ \\
$\mathrm{U}^{4+}$ & $2.543 / 2.416$ & & $1.175 / 1.182$ & $2.198 / 2.220$ \\
& $\mathbf{-}$ & & - & - \\
\hline & & & &
\end{tabular}

${ }^{a}$ Metric difference between $\mathrm{Ce}-\mathrm{C} / \mathrm{N}$ and $\mathrm{U}-\mathrm{C} / \mathrm{N}$ bond distances.

It is worth noting that the comparison between the two $\mathrm{Ce}(\mathrm{III})$ and U(III) analogous complexes $\left[\mathrm{MCp}_{2}{ }_{2}(\mathrm{CN})_{3}\right]^{2-}$ in Table 1 reveals a significant shortening of the computed metalligand bond distances when going from the cerium to the uranium species. Indeed, the $\mathrm{M}-\mathrm{CN}$ bond distances in the $\left[\mathrm{MCp}_{2}{ }_{2}(\mathrm{CN})_{3}\right]^{2-}$ gas phase species are equal to 2.665 for Ce $v s .2 .612 \AA$ for $\mathrm{U}$, and 2.535 vs. $2.492 \AA$ for the corresponding $\mathrm{M}-\mathrm{NC}$ ones in $\left[\mathrm{MCp}^{*}{ }_{2}(\mathrm{NC})_{3}\right]^{2-}$. This bond length shortening is also observed for the solvated species with a greater contraction of the $\mathrm{U}(\mathrm{III})-\mathrm{CN} / \mathrm{NC}$ bond distances comparatively to the $\mathrm{Ce}$ (III) species. The metric difference $\Delta$ between the $\mathrm{Ce}-\mathrm{C} / \mathrm{N}$ and $\mathrm{U}-\mathrm{C} / \mathrm{N}$ bond distances computed at the ZORA/BP86/DZP level is predicted to be larger for the cyanide $\mathrm{CN}$ than for the isocyanide $\mathrm{NC}$ ligand (0.053 vs. 0.043 
$\AA$ ), which is slightly amplified by solvation (0.070 vs. $0.057 \AA)$, suggesting that the former, i.e., the cyanide form, leads to a more covalent bonding than the isocyanide one. These features illustrate the distinct coordination modes of these two ligands towards the Ce(III) and U(III) ions, as experimentally observed.

The U-CN/NC bond length shortening relatively to $\mathrm{Ce}-\mathrm{CN} / \mathrm{NC}$ is also observed for the $\mathrm{U}-$ $\mathrm{L}\left(\mathrm{L}=\mathrm{Cp}^{*}\right.$ and $\left.\mathrm{N}^{*}\right)$ coordination. Moreover, no significant difference is computed for $\mathrm{C}-$ $\mathrm{N} / \mathrm{N}-\mathrm{C}$ distances when moving from $\mathrm{Ce}(\mathrm{III})$ to $\mathrm{U}(\mathrm{III})$ complexes, suggesting that no $\mathrm{M} \rightarrow \mathrm{X} \pi$ back-donation occurs, and that the $\mathrm{M}-\mathrm{X}$ bond is essentially $\sigma$ in character. The electronic structure analysis will shed light on these points.

\subsection{Electronic structures of the tris(cyanide) complexes}

As reported previously for the bis(cyanide) compounds $\left[\mathrm{MN}_{3} \mathrm{X}_{2}\right]^{2-}\left(\mathrm{M}=\mathrm{Ce}^{\mathrm{III}}\right.$ and $\mathrm{U}^{\mathrm{III}}, \mathrm{X}$ $=\mathrm{C}-\mathrm{N} / \mathrm{N}-\mathrm{C}$ ) [10a], the better energy matching of the $\mathrm{C}$-localized $\sigma$ lone pair orbital of the cyanide ligand with the $\mathrm{U}^{\mathrm{III}}\left(5 f^{3}\right)$ metal-based orbitals makes it a much more effective donor than the N-localized $\sigma$ orbital, which is much lower in energy [9]. This feature was also reported to explain the cyanide $\mathrm{U}(\mathrm{III})-\mathrm{CN}$ and isocyanide $\mathrm{U}(\mathrm{IV})-\mathrm{NC}$ coordination mode in the $\left[\mathrm{UN}_{3}{ }_{3} \mathrm{X}_{2}\right]^{2-/ 1-}$ complexes $[10 \mathrm{~b}]$. To investigate further the electronic structure and metalligand bonding, natural bond order/natural population analyses (NBO/NPA) [16a] (see Appendix A, computational details) were performed on the optimized geometries of the cyanide and isocyanide systems at the ZORA/BP86/DZP level. The NPA approach proved to probe the covalency in $f$-element complexes with results in better agreement with experimental trends [16b,c,d] than the Mulliken population analysis (MPA) [16e], especially in the context of lanthanide(III)/actinide(III) differentiation $[10,11,16 f]$.

NPA results for the complexes $\left[\mathrm{ML}_{2} \mathrm{X}_{3}\right]^{2-}\left(\mathrm{M}=\mathrm{Ce}^{3+}, \mathrm{U}^{3+} ; \mathrm{L}=\mathrm{Cp}^{*} / \mathrm{N}^{*} ; \mathrm{X}=\mathrm{CN} / \mathrm{NC}\right)$ under consideration are given in Table 2. Natural metal $\left(\mathrm{q}_{\mathrm{M}}\right)$, carbon and nitrogen atomic net charges as well as the metallic spin population $\rho_{M}$ are reported. $\rho_{M}$ is computed to be the difference between the total $\alpha$ and $\beta$ spin electronic populations. In the case of the bis(cyclopentadienyl) $\mathrm{MCp}_{2}{ }_{2}(\mathrm{CN})_{3}$ complexes, examination of the NPA results (Table 2) indicates a small difference between the metal natural charges $\left(\mathrm{q}_{\mathrm{M}}\right)$ for the cyanide $\mathrm{M}-\mathrm{CN}$ and isocyanide $\mathrm{M}-\mathrm{NC}$ complexes $(+1.53 /+1.74)$ for $\mathrm{Ce}^{3+}$ and $\left(+0.73 /+1.03\right.$ for $\left.\mathrm{U}^{3+}\right)$ which are consistent with the slightly stronger $\sigma$-donation of the cyanide ligand to the U(III) ion, since 
the ligand-to-metal donation is stronger when the positive metallic net charge becomes smaller, in agreement with previous findings [10a]. This difference becomes more pronounced when the two $\mathrm{Ce}(\mathrm{III}) / \mathrm{U}(\mathrm{III})-\mathrm{X}$ systems are compared (namely +1.53 for cerium vs. +0.73 for uranium, in the case of a $\mathrm{CN}$ coordination), which could account for $\mathrm{Ce}(\mathrm{III}) / \mathrm{U}(\mathrm{III})$ differentiation. In the case of the bis(silylamide) $\mathrm{MN}_{2} *$ complexes, the metal natural charge $\left(\mathrm{q}_{\mathrm{M}}\right)$ for the cyanide $\mathrm{U}-\mathrm{CN}$ is lower than for the isocyanide $\mathrm{U}-\mathrm{NC}$ (namely $+1.30 v s .+1.54)$ indicating a stronger ligand-to-metal donation, and it is also lower than for the cyanide $\mathrm{Ce}-\mathrm{CN}$ ones $($ i.e., +1.71$)$ consistent with the $\mathrm{U}-\mathrm{CN} / \mathrm{NC}$ bond length shortening relatively to $\mathrm{Ce}-\mathrm{CN} / \mathrm{NC}$. It is noteworthy that solvation effects do not modify the trends observed for the isolated complexes.

\section{Table 2}

ZORA/BP86/DZP NPA results for the $\left[\mathrm{MCp}_{2}{ }_{2} \mathrm{X}_{3}\right]^{2-}$ and $\left[\mathrm{MN}_{2}{ }_{2} \mathrm{X}_{3}\right]^{2-}\left(\mathrm{M}=\mathrm{Ce}^{3+}, \mathrm{U}^{3+}, \mathrm{X}=\right.$ $\mathrm{CN} / \mathrm{NC}$ ) complexes in the gas phase and in solution (in italics).

\begin{tabular}{|c|c|c|c|c|}
\hline \multirow{2}{*}{$\begin{array}{c}\mathrm{M}-(\mathrm{CN} / \mathrm{NC}) \\
\text { Structure }\end{array}$} & \multicolumn{3}{|c|}{ NPA spin population } & NPA net charge \\
\hline & $\rho_{\mathrm{M}}$ & $\mathrm{q}_{\mathrm{M}}$ & $\langle\mathrm{C}-\mathrm{N}\rangle$ & $\langle\mathrm{N}-\mathrm{C}\rangle$ \\
\hline \multicolumn{5}{|c|}{$\left[\mathrm{MCp}_{2}{ }_{2} \mathrm{X}_{3}\right]^{2-}$} \\
\hline \multirow[t]{2}{*}{$\mathrm{Ce}(\mathrm{III})$} & $0.989 / 0.993$ & $+1.53 /+1.74$ & $-0.12:-0.57$ & $-0.81:+0.04$ \\
\hline & $0.985 / 0.981$ & $+1.49 /+1.72$ & $-0.28:-0.63$ & $-0.76:-0.01$ \\
\hline \multirow[t]{3}{*}{ U(III) } & $2.913 / 2.898$ & $+0.73 /+1.03$ & $-0.23:-0.56$ & $-0.71:+0.05$ \\
\hline & $2.874 / 2.873$ & $+0.56 /+1.01$ & $+0.05:-0.63$ & $-0.66:-0.04$ \\
\hline & & {$\left[\mathrm{MN} *{ }_{2} \mathrm{X}\right.$} & & \\
\hline \multirow[t]{2}{*}{$\mathrm{Ce}(\mathrm{III})$} & $1.019 / 1.018$ & $+1.71 /+1.88$ & $-0.17:-0.54$ & $-0.85:+0.09$ \\
\hline & $1.003 / 1.016$ & $+1.66 /+1.86$ & $-0.11:-0.61$ & $-0.80:+0.02$ \\
\hline \multirow[t]{2}{*}{$\mathrm{U}(\mathrm{III})$} & $2.949 / 2.921$ & $+1.30 /+1.54$ & $-0.11:-0.53$ & $-0.85:+0.10$ \\
\hline & $2.929 / 2.901$ & $+1.23 /+1.50$ & $-0.04:-0.59$ & $-0.70:+0.03$ \\
\hline
\end{tabular}

Comparison of the charge distribution on the $\mathrm{C}-\mathrm{N}$ coordination reveals a slightly but significantly lower $\mathrm{C}$ cyanide natural charge in U(III) than in Ce(III) species, especially for the bis(silylamide) $\mathrm{MN}_{2} *$ complexes (e.g., $-0.11 v s$. -0.17 ), which sustains its stronger $\sigma$ donation for the actinide system (in vacuum). These trends seem to be amplified by solvation, since the negative net charge borne by the $\mathrm{C}$ cyanide in the $\mathrm{U}$ (III) system decreases significantly $(-0.11 \mathrm{vs}$. -0.04$)$, sustaining its stronger $\sigma$-donation towards the actinide ion. Interestingly, the total charges of the $\mathrm{C}-\mathrm{N}$ moiety in the case of $\mathrm{Ce}(\mathrm{III})$ and $\mathrm{U}(\mathrm{III})$ cyanide coordination are equal to $-0.69 v s$. -0.79 for the $\mathrm{MCp}^{*}{ }_{2}$ complexes and -0.71 vs. -0.64 for 
the $\mathrm{MN}_{2}{ }^{*}$ ones, respectively. Similarly, the total charges of the $\mathrm{N}-\mathrm{C}$ isocyanide for the $\mathrm{Ce}(\mathrm{III})$ and $\mathrm{U}(\mathrm{III})$ systems, equal to -0.77 vs. -0.66 and -0.76 vs. -0.75 for the two $\mathrm{MCp}{ }^{*}$ and $\mathrm{MN}_{2} *$ systems, respectively, show that the isocyanide donation ability is similar in the bis(silylamide) complexes. Thus, it seems that the stronger $\mathrm{C}$ cyanide covalent bonding towards $\mathrm{UN}_{2} *$ moieties contributes to the chosen coordination mode of this species. The covalent factors, presumably slight, likely to originate mainly from the cyanide and/or isocyanide $\sigma$-donation abilities and the better energy matching between metallic orbitals $\mathrm{d} / \mathrm{f}$ and ligand orbitals, are responsible for the $\mathrm{Ce}(\mathrm{III}) / \mathrm{U}(\mathrm{III})$ differentiation, this point being supported by bond order (BO) calculations. To further assess these electronic factors, i.e., the ionic and/or covalent contribution to the cyanide/isocyanide coordination preference, the Nalewajski-Mrozek (NM) bond indices [17a,b] and Mayer bond orders [17c] for the M$\mathrm{CN} / \mathrm{NC}$ and $\mathrm{C}-\mathrm{N} / \mathrm{N}-\mathrm{C}$ bonds were computed and are reported in Table 3.

\section{Table 3}

ZORA/BP86/DZP Mayer bond orders and Nalewajski-Mrozek (NM) bond indices for the $\left[\mathrm{ML}_{2} \mathrm{X}_{3}\right]^{2-}\left(\mathrm{M}=\mathrm{Ce}^{3+}, \mathrm{U}^{3+} ; \mathrm{L}=\mathrm{Cp}^{*}, \mathrm{~N}^{*} ; \mathrm{X}=\mathrm{CN} / \mathrm{NC}\right)$ complexes in the gas phase and in solution (in italics).

\begin{tabular}{|c|c|c|c|c|c|c|}
\hline \multirow{2}{*}{\multicolumn{2}{|c|}{ Compound }} & \multirow{2}{*}{$\begin{array}{c}\mathrm{M}-(\mathrm{CN} / \mathrm{NC}) \\
(\AA)\end{array}$} & \multirow{2}{*}{\multicolumn{2}{|c|}{ Mayer bond order }} & \multirow{2}{*}{\multicolumn{2}{|c|}{ NM bond index }} \\
\hline & & & & & & \\
\hline \multirow{4}{*}[\mathrm{MCp}^{*}{}_{2}\mathrm{X}_{3}]{$^{2-}$} & $\mathrm{Ce}(\mathrm{III})$ & $2.665 / 2.535$ & $0.447 / 0.387$ & $2.814 / 2.665$ & $0.695 / 0.642$ & $3.165 / 3.114$ \\
\hline & & $2.655 / 2.546$ & $0.431 / 0.361$ & $2.835 / 2.755$ & $0.687 / 0.612$ & $3.168 / 3.156$ \\
\hline & U(III) & $2.612 / 2.492$ & $0.529 / 0.466$ & $2.759 / 2.624$ & $0.837 / 0.801$ & $3.117 / 3.059$ \\
\hline & & $2.585 / 2.489$ & $0.530 / 0.445$ & $2.780 / 2.712$ & $0.859 / 0.785$ & $3.100 / 3.054$ \\
\hline \multirow[t]{4}{*}[\mathrm{MN}^{*}{}_{2}\mathrm{X}_{3}]{$^{2-}$} & $\mathrm{Ce}(\mathrm{III})$ & $2.666 / 2.511$ & $0.440 / 0.396$ & $2.829 / 2.633$ & $0.838 / 0.952$ & $3.192 / 3.109$ \\
\hline & & $2.657 / 2.523$ & $0.426 / 0.364$ & $2.841 / 2.723$ & $0.796 / 0.894$ & $3.190 / 3.152$ \\
\hline & U(III) & $2.605 / 2.462$ & $0.540 / 0.491$ & $2.777 / 2.585$ & $0.885 / 0.868$ & $3.130 / 3.043$ \\
\hline & & $2.593 / 2.472$ & $0.532 / 0.467$ & $2.790 / 2.670$ & $0.882 / 0.830$ & $3.123 / 3.078$ \\
\hline
\end{tabular}

As expected, the NM approach, which accounts for both ionic and covalent contributions, gives greater metal-ligand bond orders, up to two times, than Mayer ones which essentially takes into account covalent contributions. It is noteworthy that NM and Mayer analyses give larger $\mathrm{M}-\mathrm{CN} / \mathrm{NC} \mathrm{BOs}$ for uranium complexes than for their cerium congeners, correlating well with structural features and NPA results. For the $\mathrm{C}-\mathrm{N} / \mathrm{N}-\mathrm{C}$ bonds, the covalent character is high, so that the NM and Mayer indices get closer. It is worth noting that for all systems, Mayer analysis, consistently gives $\mathrm{M}-\mathrm{C}$ cyanide bond orders higher than $\mathrm{M}-\mathrm{N}$ isocyanide ones, e.g. 0.447 vs. 0.387 and 0.529 vs. 0.446 for $\mathrm{CeCp}_{2}{ }_{2}$ and $\mathrm{UCp}_{2}{ }_{2}$ systems, respectively. 
These trends, namely higher BOs for $\mathrm{M}-\mathrm{C}$ cyanide than for isocyanide $\mathrm{M}-\mathrm{N}$ coordination, are corroborated by the $\mathrm{NM}$ results for the bis(cyclopentadienyl) $\mathrm{MCp}^{*}{ }_{2}$ systems. On the other hand, this is the opposite is computed for the bis(silylamide) $\mathrm{MN}_{2}{ }_{2}$ species. Indeed, the isocyanide $\mathrm{Ce}-\mathrm{N} \mathrm{NM}$ is predicted to be higher than the $\mathrm{Ce}-\mathrm{C}$ cyanide one (0.952 vs. 0. 838) in the $\mathrm{CeN}^{*}{ }_{2}$ system, whereas the opposite is computed for the $\mathrm{UN}^{*}{ }_{2}$ congeners, the $\mathrm{U}-\mathrm{C} \mathrm{NM}$ being slightly but significantly higher than the $\mathrm{U}-\mathrm{N}$ one $(0.885 v s$. 0.868), in accordance with the experimental observation. The NM approach correlates well with the experimental structural data and as stated recently by other works, $[10,17 \mathrm{~d}]$ appears to be more reliable because it both accounts for ionic and covalent contribution. Notably, the slight difference between the cyanide $\mathrm{M}-\mathrm{C}$ and isocyanide $\mathrm{M}-\mathrm{N}$ Nalewajski-Mrozek BOs reflects the subtle balance between the ionic/covalent contributions in their coordination preference. It is noteworthy that the computed COSMO/THF results performed to take account of the solvation species in solution are in line with the gas phase ones and confirm the crucial role of the bis(silylamide) $\mathrm{MN}_{2}{ }_{2}$ co-ligand in the $\mathrm{Ln}(\mathrm{III}) / \mathrm{An}(\mathrm{III})$ differentiation.

\subsection{Molecular orbital (MO) analysis of the tris(cyanide) complexes}

MO frontier diagrams of the trivalent complexes $\left[\mathrm{ML}_{2} \mathrm{X}_{3}\right]^{2-}\left(\mathrm{M}=\mathrm{Ce}^{3+}\right.$ or $\mathrm{U}^{3+} ; \mathrm{L}=\mathrm{Cp}^{*}$ or $\mathrm{N}^{*} ; \mathrm{X}=\mathrm{CN} / \mathrm{NC}$ ) are given in Fig. 3 and 4. For the sake of simplicity, only $\alpha$ spin-MOs are shown. Different sets of MOs appear. For all cyanide and isocyanide complexes, the diagrams show that the highest occupied $\alpha$ spin-orbitals, i.e., the SOMO, SOMO-1 and SOMO-2 in $\mathrm{U}(\mathrm{III})\left(f^{3}\right)$ complexes and the SOMO in the Ce(III) $\left(f^{1}\right)$ counterpart are essentially metallic in character, with a strong $f$ orbital contribution. In the case of the U(III) systems, a weak cyanide or isocyanide ligand contribution of $c a .4 \%$ is observed in the SOMOs. However, neither presence of metal-to-ligand $\pi$ back-donation nor $\pi$ interaction appears between the metal center and the cyanide or isocyanide ligands, since the participation of the C-localized orbital of $\mathrm{CN}^{-}$or $\mathrm{N}$-localized orbital of $\mathrm{NC}^{-}$is null. This confirms the fact that these ligands remain mainly $\sigma$ donors in character in these species. 


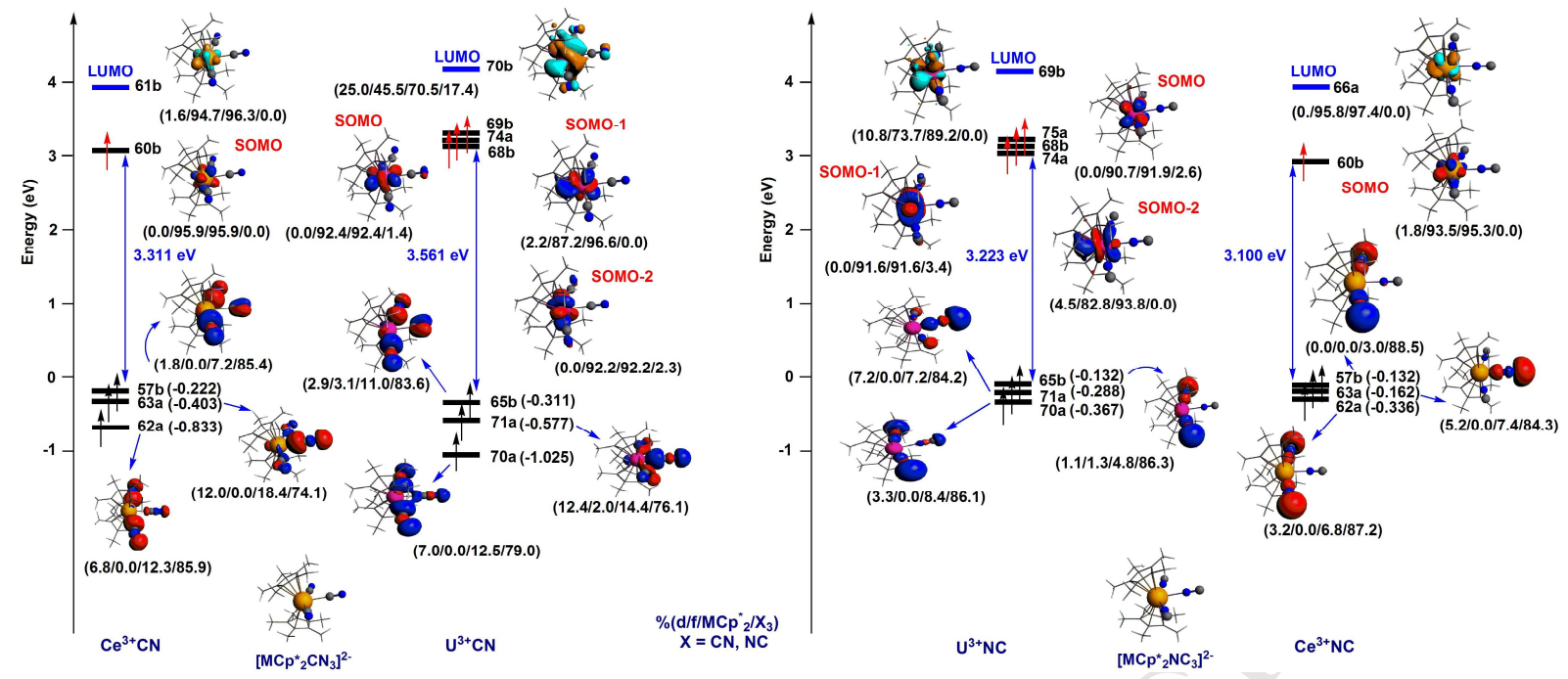

Fig. 3. ZORA/BP86/DZP $\alpha$ spin-MO diagram for $\mathrm{M}-\mathrm{CN}$ (left) and $\mathrm{M}-\mathrm{NC}$ (right) $\left[\mathrm{MCp}_{2}{ }_{2} \mathrm{X}_{3}\right]^{2-}(\mathrm{X}=\mathrm{CN} / \mathrm{NC})$ complexes $\left(C_{2}\right.$ symmetry $)$. From the left to the right, the $\mathrm{M} d, \mathrm{M} f$, $\mathrm{ML}_{2}$, and $\mathrm{X}_{3}$ percentage contributions are given in brackets. Contour values are \pm 0.03 $\left(\mathrm{e} / \mathrm{bohr}^{3}\right)^{1 / 2}$.

More interestingly, the sets of occupied M-CN/NC MOs, deeper in energy, exhibit mainly the $\sigma$ donation character of the $\mathrm{CN}$ or $\mathrm{NC}$ ligand. First of all, the comparison of the electronic structure of the cyanide $\mathrm{U}-\mathrm{CN}$ and $\mathrm{Ce}-\mathrm{CN}$ compounds with that of their isocyanide congeners in the $\left[\mathrm{MCp}_{2}{ }_{2} \mathrm{X}_{3}\right]^{2-}$ complexes (Fig. 3), reveals that the metal $d / f$ orbitals weight is slightly larger for the cyanide $\mathrm{M}-\mathrm{CN}$ complexes than for their M-NC analogues, as it can be seen in the $\sigma$-donating $62 \mathrm{a}, 63 \mathrm{a}, 57 \mathrm{~b}$ and 70a, 71a, 65b MOs, namely 7.2-18.4 vs. 11.1$14.4 \%$ for $\mathrm{Ce}-\mathrm{CN}$ and $\mathrm{U}-\mathrm{CN}$, respectively. This weight is reduced to 3.0-7.4 vs. 4.8-8.4\% for $\mathrm{Ce}-\mathrm{NC}$ and $\mathrm{U}-\mathrm{NC}$, respectively, for the same MO bonding sets. It is worth noting that the $6 d / 5 f$ actinide orbitals both contribute more significantly to the $\mathrm{U}-\mathrm{CN}$ bonding. This is in agreement with the coordination preference of uranium.

Moving back to the bis(silylamide) $\mathrm{MN}_{2}{ }_{2}$ systems, the MO diagram of Fig. 4 shows that the metal $d / f$ orbitals contributions within the bonding $\sigma$-donating pair $\mathrm{U}-\mathrm{CN} / \mathrm{NC}$, i.e., $151 \mathrm{a}$, 152a MOs are in the range 9.8-21.5 vs. 1.7-9.0\% for U-CN and U-NC, respectively, in line with NM bond orders and NPA analyses discussed above, and correlating well with the observed cyanide $\mathrm{UN}_{2}{ }_{2}-\mathrm{CN}$ coordination. Furthermore, these bonding $\sigma$-donating pairs, i.e., 151a, 152a MOs, are slightly lower in energy for the $\mathrm{U}-\mathrm{CN}$ coordination than for the hypothetical $\mathrm{U}-\mathrm{NC}$ one, namely -0.90 and $-1.12 \mathrm{vs}$. -0.61 and $-0.80 \mathrm{eV}$, respectively, sustaining the stronger interaction between the $6 d / 5 f \mathrm{U}(\mathrm{III})$ orbitals and C-cyanide ones due to a better energy matching [11]. 

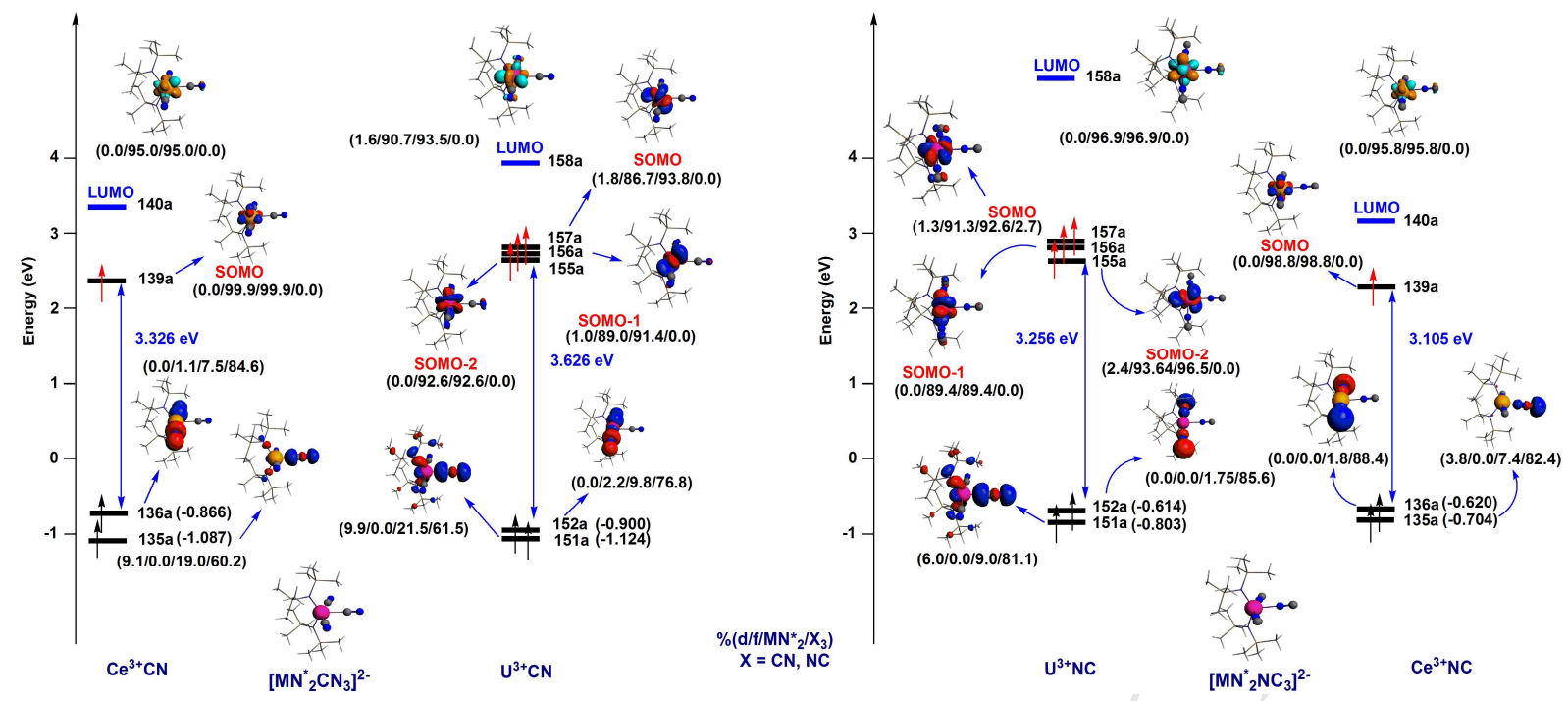

Fig. 4. ZORA/BP86/DZP $\alpha$ spin-MO diagram for $\mathrm{M}-\mathrm{CN}$ (left) and $\mathrm{M}-\mathrm{NC}$ (right) $\left[\mathrm{MN}{ }_{2} \mathrm{X}_{3}\right]^{2-}(\mathrm{X}=\mathrm{CN} / \mathrm{NC})$ complexes $\left(C_{1}\right.$ symmetry). From the left to the right, the $\mathrm{M} d, \mathrm{M} f$, $\mathrm{ML}_{2}$, and $\mathrm{X}_{3}$ percentage contributions are given in brackets. Contour values are \pm 0.03 $\left(\mathrm{e} / \mathrm{bohr}^{3}\right)^{1 / 2}$.

Considering the bis(silylamide) $\mathrm{Ce}-\mathrm{CN} / \mathrm{NC}$ pair, as shown by the $\mathrm{MO}$ analysis (Fig. 4), the 135a and 136a MOs exhibit metal contributions of 19.0 and $7.5 \%$ vs. 7.4 and $1.8 \%$ mainly $5 d$ orbitals, for $\mathrm{Ce}-\mathrm{CN}$ and $\mathrm{Ce}-\mathrm{NC}$ bonding, respectively. Moreover, the $\mathrm{Ce}-\mathrm{CN}$ bonding levels are slightly lower in energy than the $\mathrm{Ce}-\mathrm{NC}$ congeners (i.e., -0.87 and -1.09 vs. -0.62 and $-0.70 \mathrm{eV}$, respectively) and the small gap between the SOMO and the $\mathrm{Ce}-\mathrm{CN} / \mathrm{NC}$ pair $\sigma$ donating MOs (3.33 vs. $3.11 \mathrm{eV}$ ) suggest that the preferred CN/NC coordination is, in this case, under ionic or/and covalent subtle control, as noted by NPA and NM bond orders analysis (see above Tables 2 and 3).

As shown by the MO analysis (Fig. 3 and 4), the isocyanide M-NC interaction seems to be weaker than the cyanide $\mathrm{M}-\mathrm{CN}$ interaction, as corroborated by metallic percentages in bonding $\mathrm{M}-\mathrm{CN} / \mathrm{NC} \mathrm{MOs}$, which are greater in the latter. This could explain the energy stability difference between the cyanide and isocyanide systems and the coordination mode preference to the uranium(III) and cerium(III) centers.

As indicated by the electronic structure and MO analysis, the variations in structural and bonding parameters of the considered complexes could be explained by the $\sigma$-donating abilities of the cyanide and isocyanide ligands and the occurrence of a higher covalent character of the bonding in the case of the U(III) complexes. However, even though structural parameters and electronic factors can account for the latter effects [18], they cannot always 
permit to differentiate the $\mathrm{CN} / \mathrm{NC}$ coordination mode preference for actinide(III) and lanthanide(III) systems in terms of their relative stabilities, as recently noted [10a].

The chosen coordination mode is mainly driven by a good match between the energies of the metal AOs within the $\mathrm{MCp}_{2}{ }_{2}$ and $\mathrm{MN}_{2}$ fragments, and the carbon or nitrogen lone pair energies of the cyanide ligand. The energies of the metal orbitals involved in bonding with the cyanide ligand are lower by $c a .1 \mathrm{eV}$ for the $\mathrm{CeN}_{2}{ }_{2}$ fragment relatively to $\mathrm{CeCp}_{2}$. Let us remind that the nitrogen lone pair of the cyanide ligand is lower in energy than the carbon lone pair. This result would explain why in the cerium compounds the cyanide coordination is observed with the $\mathrm{Cp}^{*}{ }_{2}$ co-ligands and the isocyanide with the $\mathrm{N}_{2}$ ones. On the contrary, the cyanide coordination in the case of the uranium complexes is not uniquely driven by this sole factor, since it is observed for the two complexes under consideration. The investigation of the bonding energies is required to clarify this issue.

\subsection{Energy decomposition analysis}

In order to get some additional information on the energy factors driving the preferred coordination of the cyanide or isocyanide ligands to the cerium or uranium atoms in the actual $\left[\mathrm{ML}_{2} \mathrm{X}_{3}\right]^{2-}$ complexes $\left(\mathrm{M}=\mathrm{Ce}^{3+}\right.$ or $\mathrm{U}^{3+} ; \mathrm{L}=\mathrm{Cp}^{*}$ or $\left.\mathrm{N}^{*} ; \mathrm{X}=\mathrm{CN} / \mathrm{NC}\right)$ and their hypothetical isomers, an energy decomposition analysis was carried out (see Appendix A, computational details). The bonding energies of the ligands to the metal centers were calculated according to the following fragmentation scheme:

$$
\left[\mathrm{ML}_{2}\right]^{+}+3 \mathrm{X}^{-} \rightarrow\left[\mathrm{ML}_{2} \mathrm{X}_{3}\right]^{2-}\left(\mathrm{L}=\mathrm{Cp}^{*} \text { or } \mathrm{N}^{*} ; \mathrm{X}=\mathrm{CN} \text { or } \mathrm{NC}\right)
$$

These total bonding energies $\left(\mathrm{TBE}_{\text {frag }}\right)$ computed at the spin unrestricted ZORA/BP86/DZP level (see Appendix) are given in Table 4.

\section{Table 4}

Energy decomposition analysis at the ZORA/BP86/DZP level for the complexes $\left[\mathrm{ML}_{2} \mathrm{X}_{3}\right]^{2-}$ $\left(\mathrm{M}=\mathrm{Ce}^{3+}\right.$ or $\mathrm{U}^{3+} ; \mathrm{L}=\mathrm{Cp}^{*}$ or $\mathrm{N}^{*} ; \mathrm{X}=\mathrm{CN}($ left $) / \mathrm{NC}($ right $\left.)\right)$ in the gas phase and in solution (in italics).

\begin{tabular}{cccccccc}
\hline ion & $E_{\text {Pauli }}(\mathrm{eV})$ & $E_{\text {elstat }}(\mathrm{eV})$ & $E_{\text {st }}(\mathrm{eV})$ & $E_{\text {orb }}(\mathrm{eV})$ & $E_{\text {solvat }}(\mathrm{eV})$ & $\mathrm{TBE}_{\text {frag }}(\mathrm{eV})$ & $\begin{array}{c}\Delta E \\
(\mathrm{kcal} / \mathrm{mol})\end{array}$ \\
\hline & & {$\left[\mathrm{MCp}_{2}{ }_{2} \mathrm{X}_{3}\right]^{2-}$} & & & \\
\hline $\mathbf{C e}^{3+}$ & $6.001 / 6.314$ & $-16.928 /-16.225$ & $-10.927 /-9.910$ & $-6.700 /-7.257$ & - & $-17.628 /-17.186$ & $0.0 / 10.1$ \\
\hline
\end{tabular}




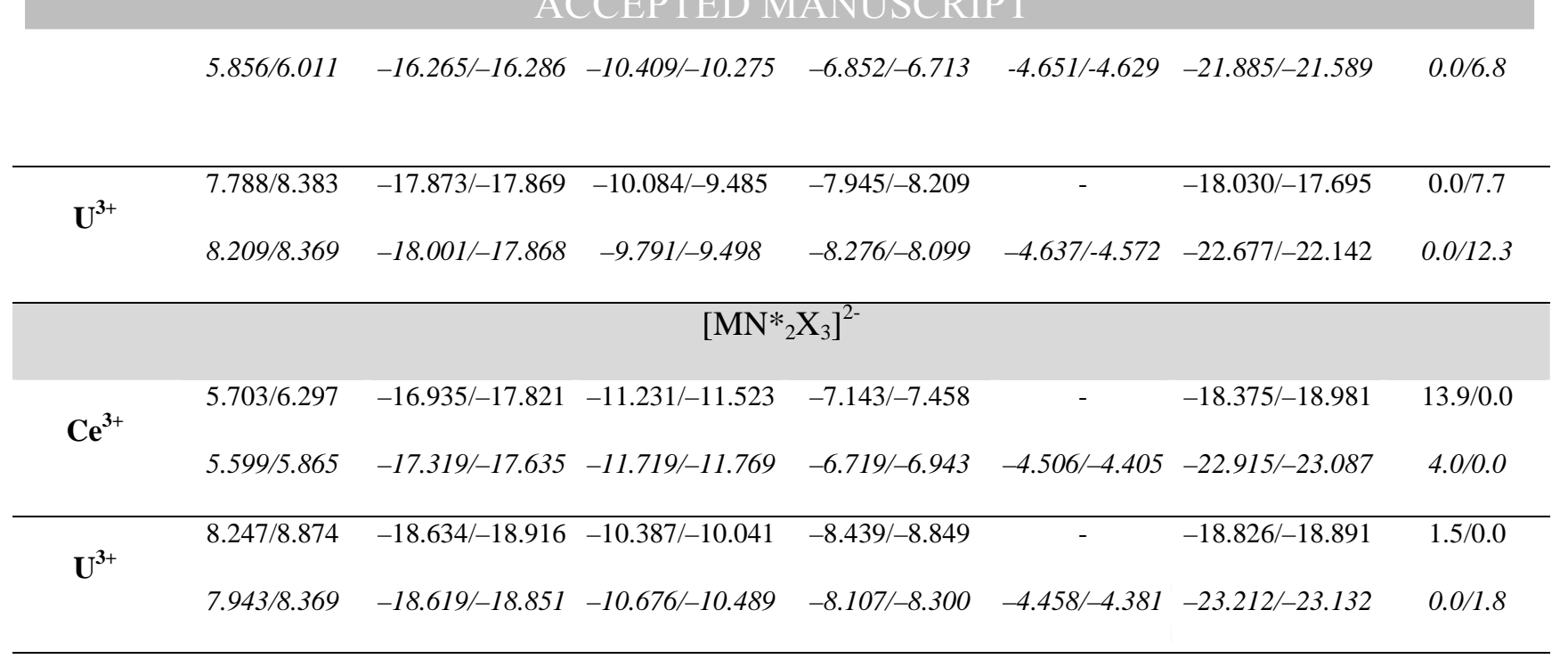

Considering first the computed energy for isolated complexes (namely in vacuum), it can be seen that the $\mathrm{TBE}_{\text {frag }}$ for the cyanide $\mathrm{M}-\mathrm{CN}$ coordination of the $\mathrm{MCp}{ }_{2}$ complexes are significantly higher (in absolute value) than the isocyanide M-NC ones, as shown by their relative stability $\Delta E$, in agreement with the experimental observation, i.e., the actual structures. We note that for the $\mathrm{MN}_{2}{ }_{2}$ complexes, the most stable species is correctly predicted for the isocyanide $\mathrm{Ce}-\mathrm{NC}$ species but not for the cyanide $\mathrm{U}-\mathrm{CN}$ species. Indeed, the relative stability given by $\Delta E$ clearly highlights the difference in $\mathrm{M}-\mathrm{CN} / \mathrm{NC}$ coordination between the $\mathrm{Ce}(\mathrm{III})$ and $\mathrm{U}(\mathrm{III})$ ions, in agreement with the experimental findings, except for the $\mathrm{UN}_{2}{ }_{2}$ complex, where $\Delta E$ in vacuum indicates a U-NC coordination, noting that the energy difference is small, $1.50 \mathrm{kcal} / \mathrm{mol}$ only.

As expected, considering the different energy terms (Table 4), the steric term $\left(E_{\mathrm{st}}\right)$ is slightly more destabilizing for the U(III) than for the Ce(III) species, especially in the bis(silylamide) $\mathrm{MN}_{2}$, due to the shorter metal-ligand distances in the former. Notably, in the bis(cyclopentadienyl) MCp* ${ }_{2}$ series, the steric term, which is the sum of the Pauli repulsion (repulsion between electron pairs) and the stabilizing electrostatic interactions, reveals that the isocyanide binding mode for the two $\mathrm{Ce}$ (III) and U(III) ions is less sterically favored than the cyanide binding mode. This is due to a higher Pauli repulsion related to smaller M-N bond lengths than $\mathrm{M}-\mathrm{C}$ ones.

More interestingly, the steric term in the bis(silylamide) $\mathrm{MN}_{2}{ }_{2}$ species reveals that the isocyanide $\mathrm{Ce}-\mathrm{NC}$ binding mode is slightly more sterically favored than the cyanide $\mathrm{Ce}-\mathrm{CN}$ one (i.e., -11.52 vs. $-11.23 \mathrm{eV}$ ) whereas the opposite is observed for the U-CN/NC 
coordination (i.e., -10.38 vs. $-10.04 \mathrm{eV}$ ), confirming the preference for the cyanide coordination mode.

The orbital term $E_{\text {orb }}$ (stabilizing energy due to orbital mixing) is slightly larger in the $\mathrm{M}-\mathrm{NC}$ case than in the $\mathrm{M}-\mathrm{CN}$ one. However, the difference is small and is due to the competitive contribution of the covalent (orbital mixing) and the polarization factors, these latter being larger for the smaller M-NC bond distances [10]. Indeed, we must keep in mind that the orbital $E_{\text {orb }}$ part includes both a polarization term due to the rearrangement of the metal and ligand charge distribution with complexation, and covalency if their orbitals overlap [19]. Unfortunately, these two terms cannot be evaluated separately [19b]. Moreover, the polarization component is likely not the same for the $\mathrm{C}$ or $\mathrm{N}$ coordination modes, so that difference in $E_{\text {orb }}$ cannot be directly related to difference in covalency. Furthermore, as stated by others authors $[9,11]$, the best energy matching between the $d / f$ orbitals and the upper Ccyanide or the lower $\mathrm{N}$-isocyanide $\sigma$-donating $\mathrm{MO}$ is likely to play a crucial role in this coordination preference.

In addition to the gas phase analysis we have also computed the complexation energies incorporating the effect of the solvent (THF) using the COSMO solvation approach (Table 4). Indeed, the main trends observed for isolated complexes are maintained in solution. Interestingly, in the case of the uranium $\left[\mathrm{UN}_{2} \mathrm{X}_{3}\right]^{2-}$ species, the $\mathrm{U}-\mathrm{CN}$ coordination appears now to be favored relatively to the U-NC one, by $1.8 \mathrm{kcal} / \mathrm{mol}$, in agreement with experimental data [10a]. This theoretical result is in line with the fact that the synthesis of this complex was made in solution. It is noteworthy that using the most extended basis set available in the ADF program for all atoms, i.e. the ZORA/TZ2P one, the coordination preference of the cyanide towards U(III) is confirmed for the bis(silylamide) complex. Indeed, the same trend is obtained, i.e. the cyano isomer is more stable than the isocyano one (by 1.2 $\mathrm{kcal} / \mathrm{mol}$ at the TZ2P level vs. $1.8 \mathrm{kcal} / \mathrm{mol}$ at the DZP one) when the solvent effect is taken into account, the opposite being obtained in the gas phase.

\section{Conclusion}

The observed distinct coordination modes of cyanide and isocyanide ligands towards cerium(III) and uranium(III) in the tris(cyanide) complexes $\left[\mathrm{ML}_{2} \mathrm{X}_{3}\right]^{2-}\left(\mathrm{M}=\mathrm{Ce}^{3+} / \mathrm{U}^{3+} ; \mathrm{L}=\right.$ $\mathrm{Cp}^{*} / \mathrm{N}^{*} ; \mathrm{X}=\mathrm{CN} / \mathrm{NC}$ ) were investigated using relativistic DFT/ZORA/BP86 computations both in the gas phase and solution. The coordination modes, $\mathrm{M}-\mathrm{CN}$ or $\mathrm{M}-\mathrm{NC}$, were well 
rationalized by the consideration of the binding energies of the cyanide and isocyanide ligands to the metal ions and by the confrontation of the DFT optimized geometries to the X-ray crystal data. The effects of cyanide and isocyanide coordination on structural properties of the complexes, especially in the bis(silylamide) compounds $\left[\mathrm{MN}_{2}{ }_{2} \mathrm{X}_{3}\right]^{2-}$, have been rationalized considering electronic indices like NPA charges and bond orders. Furthermore, the variations in structural and bonding parameters of the considered complexes could be explained by an $\mathrm{MO}$ analysis. The coordination preference of the cyanide and isocyanide ligands towards the $\left[\mathrm{MCp}_{2}{ }_{2}\right]$ and $\left[\mathrm{MN}_{2}{ }_{2}\right]$ moieties results mainly from the best energy matching between the $d / f$ metallic orbitals and the upper energy $\mathrm{C}$-cyanide or the lower $\mathrm{N}$-isocyanide $\sigma$-donating MOs. More generally, $\mathrm{MO}$ analysis shows that the stronger $\sigma$-donating ability of the cyanide ligand towards actinide bis(silylamide) systems over their cerium congeners is related to the higher covalent bonding character which plays a significant role in metal-ligand coordination preference.

The calculated total bonding energies between the $\left[\mathrm{MCp}_{2}{ }_{2}\right]$ and $\left[\mathrm{MN}_{2}\right](\mathrm{M}=\mathrm{Ce}, \mathrm{U})$ metallic fragments and the $\mathrm{CN} / \mathrm{NC}$ ligands could permit prediction of the $\mathrm{M}-\mathrm{CN} / \mathrm{NC}$ coordination preference towards the $\mathrm{Ce}(\mathrm{III}) / \mathrm{U}$ (III) pair. Indeed, considering the experimental and hypothetical structures in their gas and solvated phases, it was found that the $\mathrm{TBE}_{\text {frag }}$ bonding energies for the cyanide $\mathrm{M}-\mathrm{CN}$ coordination in the $\mathrm{MCp}_{2}$ complexes are significantly higher (in absolute value) than the isocyanide $\mathrm{M}-\mathrm{NC}$ ones, as shown by their relative stability $\Delta E$, agreeing well with the experimental structures. In the $\mathrm{MN}_{2}{ }_{2}$ series, the isocyanide $\mathrm{Ce}-\mathrm{NC}$ coordination was clearly predicted more stable than the $\mathrm{Ce}-\mathrm{CN}$ one, whereas the correct cyanide coordination of the uranium complex is found only if solvent effects are taken into account. This result is rather rewarding since the latter uranium complex has been synthesized in solution. The developed methodology seems able to predict the correct isomer with confidence in all cases. Nevertheless, the preferred cyanide or isocyanide coordination mode is driven by a subtle balance between steric, ionic or/and covalent factors, as well as solvent effects, so that it could be difficult to predict with certainty, on the basis of the theoretical computation alone, the preferred coordination mode, especially when the binding energies are not very different [10]. 


\section{Appendix A. Computational details}

All molecular geometries of the tris(cyanide) complexes $\left[\mathrm{ML}_{2} \mathrm{X}_{3}\right]^{2-}\left(\mathrm{M}=\mathrm{Ce}^{3+} / \mathrm{U}^{3+} ; \mathrm{X}=\right.$ $\left.\mathrm{CN} / \mathrm{NC} ; \mathrm{L}=\mathrm{Cp} * / \mathrm{N}^{*}\right)$ were fully optimized, starting from crystal structures where available, at the scalar relativistic DFT level of theory using the Amsterdam Density Functional (ADF2014.07) program package [20].

Scalar relativistic effects were taken into account via the Zeroth Order Regular Approximation (ZORA) [20e-g]. The Vosko-Wilk-Nusair functional (VWN) [21a] for the Local Density Approximation (LDA) and gradient corrections for exchange and correlation of Becke and Perdew (BP86 functional) [21b,c] were used for geometry optimization and analytical computation of the frequencies of the normal modes of vibration. Double- $\zeta$ Slatertype valence orbitals (STO) augmented by one set of polarization functions were used for all atoms. For all elements, the basis sets were taken from the ADF/ZORA/DZP database. Several theoretical studies have shown that such a ZORA/BP86/DZP approach reproduces the experimental geometries and ground state properties of $f$-element compounds with a satisfying accuracy [14]. Finally, for all complexes, we considered the highest $(2 S+1)$ spin state as the ground state configuration, i.e., doublet $\left(f^{1}\right)$ spin states for the $\mathrm{Ce}(\mathrm{III})$ and quartet $\left(f^{3}\right)$ for U(III) systems.

In order to provide a better understanding of the metal-ligand bonding, a Natural Population Analysis (NPA) [16a] was carried out. It has been shown that such an approach provides reliable results for $f$-element complexes [16b,c,d,f].

As the ADF program supplies an energy decomposition of the metal-ligand bonding into chemically useful terms, spin-unrestricted fragment calculations were carried out considering the two molecular moieties in interaction, i.e., $\mathrm{ML}_{2}$ and $\mathrm{X}_{3}(\mathrm{X}=\mathrm{CN} / \mathrm{NC})$ for the $\left[\mathrm{ML}_{2} \mathrm{X}_{3}\right]^{2-}$ complexes $\left(\mathrm{M}=\mathrm{Ce}\right.$ or $\mathrm{U} ; \mathrm{L}=\mathrm{N}^{*}$ or $\left.\mathrm{Cp}^{*}\right)$. This energy decomposition, which is based on the transition-state method developed by Morokuma [22a,b] and Ziegler et al. [22c], provides insights into the balance of the different bonding electronic or electrostatic factors at work between the isolated cation or metallic moiety and the ligands in a complex. Thus, within this scheme, the resulting total bonding energy $\mathrm{TBE}_{\text {frag }}$ between two fragments can be decomposed into two terms as $\mathrm{TBE}_{\text {frag }}=E_{\text {steric }}+E_{\text {orb }}$, where $E_{\text {steric }}$ is, in our case, the steric interaction energy between the $\mathrm{MCp}_{2}{ }_{2}$ or $\mathrm{MN}_{2}{ }_{2}\left(\mathrm{Cp}^{*}=\mathrm{C}_{5} \mathrm{Me}_{5}\right.$ and $\left.\mathrm{N}^{*}=\mathrm{N}\left(\mathrm{SiMe}_{3}\right)_{2}\right)$ metallic fragment and the $\mathrm{CN}$ or NC ligand and $E_{\text {orb }}$ is the orbital (covalent) contribution to the metal$\mathrm{CN} / \mathrm{NC}$ bond. The steric energy term $\left(E_{\text {steric }}\right)$ is itself decomposed into a destabilizing term 
$E_{\text {Pauli }}$, the electronic repulsion due to the Pauli principle, and $E_{\text {elstat }}$, the stabilizing electrostatic energy between the two fragments $E_{\text {steric }}=E_{\text {Pauli }}+E_{\text {elstat }}$. The bonding energies have been computed at the ZORA/BP86/DZP level. $\Delta E$ in Table 4 is the energy difference between the two $\mathrm{M}-\mathrm{CN}$ and $\mathrm{M}-\mathrm{NC}$ isomers (differences of their $\mathrm{TBE}_{\text {frag }}$ ).

\section{Appendix B. Supplementary material}

Cartesian coordinates of DFT optimized geometries.

\section{Acknowledgments}

The authors are grateful to Algerian CNEPRU (project 2015-2018: E00920140093), for financial support. GENCI-IDRIS and GENCI-CINES for an allocation of computing time (Grant No. 2015-2016-080649). The COST CM-1006 action is also acknowledged.

\section{References}

(1) (a) B.L. Kalsotra, B.D. Jain, R.K. Multani, J. Inorg. Nucl. Chem. 34 (1972) 22652269. (b) B. Kanellakopulos, E. Dornberger, H. Billich, J. Organomet. Chem. 76 (1974) C42-C44.

(2) (a) J.C. Berthet, P. Thuéry, M. Ephritikhine, Dalton Trans. 44 (2015) 7727-7742 and references therein. (b) J. Maynadié, J.C. Berthet, P. Thuéry, M. Ephritikhine, Organometallics 26 (2007) 2623-2629.

(3) (a) M. Verdaguer, A. Bleuzen, V. Marvaud, J. Vaissermann, M. Seuleiman, C. Desplanches, A. Scuiller, C. Train, R. Garde, G. Gelly, C. Lomenech, I. Rosenman, P. Veillet, C. Cartier, F. Villain, Coord. Chem. Rev. 1023 (1999) 190-192. (b) M. Ohba, H. Ōkawa, Coord. Chem. Rev. 198 (2000) 313-328. (c) P. Przychodzen, T. Korzeniak, R. Podgajny, B. Sieklucka, Coord. Chem. Rev. 250 (2006) 2234-2260. (d) S. Tanase, J. Reedijk, Coord. Chem. Rev. 250 (2006) 2501-2510. (e) S. Wang, X.H. Ding, Y.H. Li, W. Huang, Coord. Chem. Rev. 256 (2012) 439-464.

(4) (a) A. Boucekkine, L. Belkhiri, f-Element Complexes. In Comprehensive Inorganic Chemistry II, J. Reedijk, K. Poeppelmeier, Eds. Elsevier: Oxford. 9 (2013) 277-319. W.J. Evans, Organometallics 35 (2016) 3088-3100. (b) F.T. Edelmann, Coord. Chem. 
Rev. 318 (2016) 29-130. F.T. Edelmann, Coord. Chem. Rev. 284 (2015) 124-205. (c) T.J. Marks, Organometallics 32 (2013) 1133-1136.

(5) (a) M. Ephritikhine, Dalton Trans. 21 (2006), 2501-2516. (b) S.T. Liddle, D.P. Mills, Dalton Trans. (2009) 5592-5605. (c) O.P. Lam, K. Meyer, Polyhedron, 32 (2012) 1-9. (d) R.J. Baker, Coord. Chem. Rev. 256 (2012) 2843-2871. (e) T.W. Hayton, Chem. Commun. 49 (2013) 2956-2973. (f) M.B. Jones, A.J. Gaunt, Chem. Rev. 113 (2013) $1137-1198$.

(6) (a) K.L. Nash, In Handbook on the Chemistry and Physics of Rare Earths, K.A. Jr. Gschneidner, L. Eyring, G.R. Choppin, G.H. Lander, Eds. Elsevier Science: Amsterdam, The Netherlands, (1994), Vol. 18, Chapter 121. (b) The Chemistry of the Actinide and Trans-actinide Elements, 3rd ed., L.R. Morss, N.M. Edelstein, F. Fuger, Eds. Springer: Dordrecht, The Netherlands, (2006).

(7) A.E.V. Gorden, M.A. DeVore, II, B.A. Maynard, Inorg. Chem. 52 (2013) 3445-3458.

(8) N. Iché-Tarrat, N. Barros, C.J. Marsden, L. Maron, Chem. Eur. J. 14 (2008) 20932099.

(9) (a) C. Clavaguera-Sarrio, S. Hoyau, N. Ismail, C.J.J. Marsden, Phys. Chem. A. 107 (2003) 4515-4525. (b) J.L. Sonnenberg, P.J. Hay, R.L. Martin, B.E. Bursten, Inorg. Chem. 44 (2005) 2255-2262. (c) D.P. Hernández, R. Ramírez-Tagle, E. CodorniuHernández, L.A. Montero-Cabrera, R. Arratia-Pérez, Polyhedron 29 (2010) 975-984.

(10) (a) A. Hervé, Y. Bouzidi, J.C. Berthet, L. Belkhiri, P. Thuéry, A. Boucekkine, M. Ephritikhine, Inorg. Chem. 53 (2014) 6995-7013. (b) A. Hervé, Y. Bouzidi, J. C. Berthet, L. Belkhiri, P. Thuéry, A. Boucekkine, M. Ephritikhine, Inorg. Chem. 54 (2015) 2474-2490.

(11) P.L. Arnold, Z.R. Turner, N. Kaltsoyannis, P. Pelekanaki, R.M. Bellabarba, R.P. Tooze, Chem. Eur. J. 16. 16 (2010) 9623-9629.

(12) M. Straka, M. Patzschke, P. Pyykkö, Theor. Chem. Acc. 109 (2003) 332-340.

(13) (a) Q.Y. Wu, C.Z. Wang, J.H. Lan, C.L. Xiao, X.K. Wang, Y.L. Zhao, Z.F. Chai, W. Q. Shi, Inorg. Chem. 53 (2014) 9607-9614. (b) B. Averkiev, M. Mantina, R. Valero, I. Infante, A. Kovacs, D. Truhlar, L. Gagliardi, Theor. Chem. Acc. 129 (2011) 657-666.

(14) (a) M. Roger, L. Belkhiri, T. Arliguie, P. Thuery, A. Boucekkine, M. Ephritikhine, Organometallics 27 (2008) 33-42. (b) A.J. Gaunt, S.D. Reilly, A.E. Enriquez, B.J. Scott, J.A. Ibers, P. Sekar, K.I. M. Ingram, N. Kaltsoyannis, M. P. Neu, Inorg. Chem. 47 (2008) 29-41. (c) M. Roger, L. Belkhiri, P. Thuery, S. E. Bouaoud, A. Boucekkine, M. Ephritikhine, Inorg. Chem. 48 (2009) 221-230. (d) S. Meskaldji, L. Belkhiri,; T. 
Arliguie, M. Fourmigue, M. Ephritikhine, A. Boucekkine, Inorg. Chem. 49 (2010) 3192-3200. (e) S. Meskaldji, A. Zaiter, L. Belkhiri, A. Boucekkine, Theor.Chem. Acc. 131 (2012) 1151-1159. (f) B. Teyar, L. Belkhiri, K. Costuas, A. Boucekkine, K. Meyer, Inorg. Chem. 55 (2016) 2870-2881.

(15) R.D. Shannon, Acta Crystallogr, Sect. A. 32 (1976) 751-767.

(16) (a) A.E. Reed, L.A. Curtiss, F. Weinhold, Chem. Rev. 88 (1988) 899-926. (b) A.E. Clark, J.L. Sonnenberg, P.J. Hay, R.L. Martin, J. Chem. Phys.121 (2004) 2563-2570. (c) M. Straka, P. Hrobarik, M. Kaupp, J. Am. Chem. Soc. 127 (2005) 2591-2599. (d) H. Wu, Q.-Y. Wu, C-Z. Wang, J-H. Lan, Zi-R. Liu, Z-F. Chai, W-Q. Shi, Dalton Trans. 45 (2016) 8107-8117. (e) R.S. Mulliken, J. Chem. Phys. 23 (1955) 1833-1840. (f) P. Yang, I. Warnke, R.L. Martin, P.J. Hay, Organometallics 27 (2008) 1384-1392.

(a) R.F. Nalewajski, J. Mrozek, Int. J. Quant. Chem. 51 (1994) 187-200. (b) R.F. Nalewajski, J. Mrozek, A. Michalak, Int. J. Quant. Chem. 6 (1997) 589-601. (c) I. Mayer, Chem. Phys. Lett. 7 (1983) 270-274. (d) B. Sadhu, M. Sundararajan, T. Bandyopadhyay, Inorg. Chem. 55 (2016) 598-609.

(18) M.L. Neidig, D.L. Clark, R.L. Martin, Coord. Chem. Rev. 257 (2013) 394-406.

(19) (a) B. Vlaisavljevich, P. Miro, C.J. Cramer, L. Gagliardi, I. Infante, S.T. Liddle, Chem.Eur. J. 17 (2011) 8424-8433. (b) L. Petit, C. Adamo, P. Maldivi, Inorg. Chem. 45(2006) 8517-8522. (c) D. Manna, S. Mula, A. Bhattacharyy, S. Chattopadhyay, T. K. Ghanty, Dalton Trans. 44 (2015) 1332-1340.

(20) (a) G. te Velde, F.M. Bickelhaupt, S.J.A.V. Gisbergen, C. Fonseca Guerra, E.J. Baerends, J.G. Snijders, T. Ziegler, Chemistry with ADF, J. Comput. Chem. 22 (2001) 931-967. (b) C. Fonseca Guerra, J.G. Snijders, G. te Velde, E.J. Baerends, Theor. Chem. Acc. 99 (1998) 391-403. (c) ADF2014, SCM, Theoretical Chemistry, Vrije Universiteit, Amsterdam, The Netherlands, http://www.scm.com. (d) A.D. Becke, J. Chem. Phys. 88 (1988) 2547-2553. (e) E.V. Lenthe, E.J. Baerends, J.G. Snijders, J. Chem. Phys. 99 (1993) 4597-4610. (f) E.V. Lenthe, E.J. Baerends, J.G. Snijders, J. Chem. Phys. 101 (1994) 9783-9792. (g) E.V. Lenthe, A.E. Ehlers, E. J. Baerends, J. Chem. Phys. 110 (1999) 8943-8953.

(21) (a) S.D. Vosko, L. Wilk, M. Nusair, Can. J. Chem. 58 (1980) 1200-1211. (b) A.D. Becke, Phys. Rev. A. 38 (1988) 3098-3100. (c) J.P. Perdew, Phys. Rev. B 34 (1986) 7406. J.P. Perdew, in Electronic Structure of Solids'91, Ed. P. Ziesche, H. Eschrig, Akademie Verlag, Berlin, 11 (1991). (d) J.P. Perdew, Y. Wang, Phys. Rev. B 45 (1992) 13244-13249. (e) J.P. Perdew, K. Burke, M. Ernzerhof, Phys. Rev. Lett. 77 
(1996) 3865-3868. (f) J.P. Perdew, K. Burke, M. Ernzerhof, Phys. Rev. Lett. 78 (1997) 1396.

(22) (a) K. Morokuma, J. Chem. Phys. 55 (1971) 1236-1244. (b) K. Kitaura, K. Morokuma, Int. J. Quant.Chem. 10 (1976) 325-340. (c) T. Ziegler, A. Rauk, Theor. Chim. Acta. 46 (1977) 1-10. 


\section{Cyanide linkage isomerism in cerium(III) and uranium(III) complexes. A relativistic DFT study}

Yamina Bouzidi a,b, Lotfi Belkhiri ${ }^{\mathrm{b},{ }^{*}}$, Michel Ephritikhine ${ }^{\mathrm{c}}$, Jean-François Halet ${ }^{\mathrm{d}, *}$, and Abdou Boucekkine ${ }^{\mathrm{d}, *}$

${ }^{a}$ Département de Chimie, Université de Batna 1, 05000 Batna, Algeria

${ }^{\mathrm{b}}$ URCHEMS, Département de Chimie, Université des Frères Mentouri Constantine 1, 25017 Constantine, Algeria

${ }^{\mathrm{c}}$ NIMBE, CEA, CNRS, Université Paris-Saclay,CEA Saclay, 91191 Gif-sur-Yvette, France

${ }^{\mathrm{d}}$ Institut des Sciences Chimiques de Rennes, UMR 6226 CNRS - Université de Rennes 1, 35042 Rennes Cedex, France

\section{Highlights}

- Different ligation modes of cyanide/isocyanide ligands towards trivalent $\mathrm{Ce}(\mathrm{III}) / \mathrm{U}(\mathrm{III})$ ions.

- Relativistic DFT/ZORA investigation accounting solvation effects.

- Dependence of the $\mathrm{M}-\mathrm{CN} / \mathrm{NC}$ coordination preference on the steric, ionic, covalent factors, co-ligand, and solvation effects. 


\section{Cyanide linkage isomerism in cerium(III) and uranium(III) complexes. A relativistic DFT study}

Yamina Bouzidi ${ }^{\mathrm{a}, \mathrm{b}}$, Lotfi Belkhiri ${ }^{\mathrm{b},{ }^{*}}$, Michel Ephritikhine ${ }^{\mathrm{c}}$, Jean-François Halet ${ }^{\mathrm{d}, *}$, and Abdou Boucekkine ${ }^{\mathrm{d}, *}$

${ }^{a}$ Département de Chimie, Université de Batna 1, 05000 Batna, Algeria

${ }^{\mathrm{b}}$ URCHEMS, Département de Chimie, Université des Frères Mentouri Constantine 1, 25017 Constantine, Algeria

${ }^{\mathrm{c}}$ NIMBE, CEA, CNRS, Université Paris-Saclay,CEA Saclay, 91191 Gif-sur-Yvette,

France

${ }^{\mathrm{d}}$ Institut des Sciences Chimiques de Rennes, UMR 6226 CNRS - Université de Rennes 1, 35042 Rennes Cedex, France

\section{Supplementary Information}


Cartesian coordinates of DFT optimized geometries.

\begin{tabular}{|c|c|c|c|c|c|c|c|}
\hline \multicolumn{8}{|c|}{$\left[\mathrm{MCp}{ }_{2}{ }_{2} \mathrm{X}_{3}\right]^{\mathrm{q}} / \mathrm{q}=2-, 1-/ \mathrm{X}=\mathrm{CN}, \mathrm{NC} / \mathrm{GAZ}$} \\
\hline \multicolumn{4}{|c|}{ 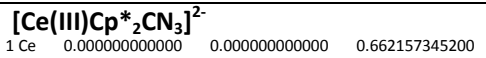 } & \multicolumn{4}{|c|}{ 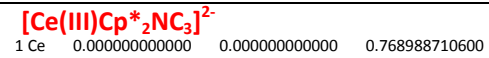 } \\
\hline $2 \mathrm{~N}$ & 0.000000000000 & 0.000000000000 & 4.473082654000 & $2 c$ & 0.000000000000 & 0.000000000000 & 4.446721466000 \\
\hline $3 \mathrm{~N}$ & -0.603426950800 & 3.736948879000 & 1.406183130000 & $3 c$ & -0.369424745800 & 3.662852699000 & 1.420315226000 \\
\hline $4 \mathrm{C}$ & 0.000000000000 & 0.000000000000 & 3.295433151000 & $4 \mathrm{~N}$ & 0.000000000000 & 0.000000000000 & 3.264089134000 \\
\hline $5 \mathrm{C}$ & -0.417392077300 & 2.585003675000 & 1.241293223000 & $5 \mathrm{~N}$ & -0.253396091900 & 2.503149597000 & 1.223800742000 \\
\hline $6 \mathrm{C}$ & 2.047694898000 & 0.343201361900 & -1.382503998000 & $6 C$ & 2.039385842000 & 0.200771171200 & -1.376836986000 \\
\hline $7 \mathrm{C}$ & 2.130878989000 & 1.521198489000 & -0.581825116900 & $7 c$ & 2.187950419000 & 1.379417240000 & -0.590108161000 \\
\hline $8 \mathrm{C}$ & 2.628106787000 & 1.141088081000 & 0.701578806600 & $8 \mathrm{C}$ & 2.669558318000 & 0.987747457600 & 0.695479695500 \\
\hline $9 \mathrm{C}$ & 2.853257207000 & -0.265610856700 & 0.690675451800 & $9 \mathrm{c}$ & 2.817518516000 & -0.430856334500 & 0.698246513500 \\
\hline $10 \mathrm{C}$ & 2.493862205000 & -0.762946573500 & -0.598896747200 & $10 \mathrm{C}$ & 2.430028796000 & -0.918002202200 & -0.586246219300 \\
\hline $11 \mathrm{C}$ & 1.763758775000 & 0.309156840900 & -2.856446193000 & $11 \mathrm{C}$ & 1.754127382000 & 0.169934613600 & -2.849472099000 \\
\hline $12 \mathrm{H}$ & 2.680382217000 & 0.494954075400 & -3.449472830000 & $12 \mathrm{H}$ & 2.684186600000 & 0.271383501500 & -3.441961765000 \\
\hline $13 \mathrm{H}$ & 1.030792118000 & 1.071770170000 & -3.158556435000 & $13 \mathrm{H}$ & 1.088167717000 & 0.987568192300 & -3.159991866000 \\
\hline $14 \mathrm{H}$ & 1.369676232000 & -0.665466803000 & -3.178561441000 & $14 \mathrm{H}$ & 1.279571213000 & -0.771541507400 & -3.160577215000 \\
\hline $15 \mathrm{C}$ & 1.916794684000 & 2.926203279000 & -1.065870868000 & $15 \mathrm{C}$ & 2.046311331000 & 2.788255056000 & -1.085146770000 \\
\hline $16 \mathrm{H}$ & 1.514268595000 & 3.573179139000 & -0.274856437100 & $16 \mathrm{H}$ & 1.695030545000 & 3.462182308000 & -0.292950408300 \\
\hline $17 \mathrm{H}$ & 1.198637064000 & 2.965456791000 & -1.898583752000 & $17 \mathrm{H}$ & 1.316559507000 & 2.860820959000 & -1.905139388000 \\
\hline $18 \mathrm{H}$ & 2.861825480000 & 3.371929563000 & -1.433355235000 & $18 \mathrm{H}$ & 3.008713897000 & 3.177968823000 & -1.470937402000 \\
\hline $19 \mathrm{C}$ & 2.930879266000 & 2.072843034000 & 1.839840410000 & $19 \mathrm{C}$ & 3.046120978000 & 1.915449612000 & 1.814296221000 \\
\hline $20 \mathrm{H}$ & 2.782777209000 & 1.582003551000 & 2.812127215000 & $20 \mathrm{H}$ & 2.919127271000 & 1.436812229000 & 2.795402331000 \\
\hline $21 \mathrm{H}$ & 2.269486591000 & 2.949340862000 & 1.825595948000 & $21 \mathrm{H}$ & 2.416256343000 & 2.815095989000 & 1.817348475000 \\
\hline $22 \mathrm{H}$ & 3.977936681000 & 2.430004259000 & 1.800274464000 & $22 \mathrm{H}$ & 4.102987391000 & 2.234978837000 & 1.734084785000 \\
\hline $23 \mathrm{C}$ & 3.439587092000 & -1.069484386000 & 1.815420425000 & $23 \mathrm{C}$ & 3.375816230000 & -1.258270554000 & 1.820024837000 \\
\hline $24 \mathrm{H}$ & 4.545724150000 & -1.073911782000 & 1.771362271000 & $24 \mathrm{H}$ & 4.478192557000 & -1.335862379000 & 1.754326657000 \\
\hline $25 \mathrm{H}$ & 3.091512981000 & -2.110833485000 & 1.787791054000 & $25 \mathrm{H}$ & 2.961021238000 & -2.275037557000 & 1.810327466000 \\
\hline $26 \mathrm{H}$ & 3.147052070000 & -0.665089863100 & 2.794494635000 & $26 \mathrm{H}$ & 3.132332912000 & -0.827100924000 & 2.801233902000 \\
\hline $27 \mathrm{C}$ & 2.720429876000 & -2.159634770000 & -1.100494159000 & $27 \mathrm{C}$ & 2.585843711000 & -2.327725755000 & -1.074191927000 \\
\hline $28 \mathrm{H}$ & 2.020262807000 & -2.423856496000 & -1.907678999000 & $28 \mathrm{H}$ & 1.913818845000 & -2.543422017000 & -1.917979387000 \\
\hline $29 \mathrm{H}$ & 2.575483748000 & -2.904209797000 & -0.306837864500 & $29 \mathrm{H}$ & 2.348655216000 & -3.057660065000 & -0.288874733400 \\
\hline $30 \mathrm{H}$ & 3.743248668000 & -2.278947694000 & -1.508034534000 & $30 \mathrm{H}$ & 3.618698961000 & -2.518689391000 & -1.424370678000 \\
\hline $31 \mathrm{~N}$ & 0.603426950800 & -3.736948879000 & 1.406183130000 & $31 \mathrm{C}$ & 0.369424745800 & -3.662852699000 & 1.420315226000 \\
\hline $32 \mathrm{C}$ & 0.417392077300 & -2.585003675000 & 1.241293223000 & $32 \mathrm{~N}$ & 0.253396091900 & -2.503149597000 & 1.223800742000 \\
\hline $33 c$ & -2.047694898000 & -0.343201361900 & -1.382503998000 & $33 \mathrm{C}$ & -2.039385842000 & -0.200771171200 & -1.376836986000 \\
\hline $34 \mathrm{C}$ & -2.130878989000 & -1.521198489000 & -0.581825116900 & $34 \mathrm{C}$ & -2.187950419000 & -1.379417240000 & -0.590108161000 \\
\hline $35 \mathrm{C}$ & -2.628106787000 & -1.141088081000 & 0.701578806600 & $35 \mathrm{C}$ & -2.669558318000 & -0.987747457600 & 0.695479695500 \\
\hline $36 \mathrm{c}$ & -2.853257207000 & 0.265610856700 & 0.690675451800 & $36 \mathrm{C}$ & -2.817518516000 & 0.430856334500 & 0.698246513500 \\
\hline $37 \mathrm{C}$ & -2.493862205000 & 0.762946573500 & -0.598896747200 & $37 \mathrm{C}$ & -2.430028796000 & 0.918002202200 & -0.586246219300 \\
\hline $38 \mathrm{C}$ & -1.763758775000 & -0.309156840900 & -2.856446193000 & $38 \mathrm{C}$ & -1.754127382000 & -0.169934613600 & -2.849472099000 \\
\hline $39 \mathrm{H}$ & -2.680382217000 & -0.494954075400 & -3.449472830000 & $39 \mathrm{H}$ & -2.684186600000 & -0.271383501500 & -3.441961765000 \\
\hline $40 \mathrm{H}$ & -1.030792118000 & -1.071770170000 & -3.158556435000 & $40 \mathrm{H}$ & -1.088167717000 & -0.987568192300 & -3.159991866000 \\
\hline $41 \mathrm{H}$ & -1.369676232000 & 0.665466803000 & -3.178561441000 & $41 \mathrm{H}$ & -1.279571213000 & 0.771541507400 & -3.160577215000 \\
\hline $42 \mathrm{C}$ & -1.916794684000 & -2.926203279000 & -1.065870868000 & $42 \mathrm{C}$ & -2.046311331000 & -2.788255056000 & -1.085146770000 \\
\hline $43 \mathrm{H}$ & -1.514268595000 & -3.573179139000 & -0.274856437100 & $43 \mathrm{H}$ & -1.695030545000 & -3.462182308000 & -0.292950408300 \\
\hline $44 \mathrm{H}$ & -1.198637064000 & -2.965456791000 & -1.898583752000 & $44 \mathrm{H}$ & -1.316559507000 & -2.860820959000 & -1.905139388000 \\
\hline $45 \mathrm{H}$ & -2.861825480000 & -3.371929563000 & -1.433355235000 & $45 \mathrm{H}$ & -3.008713897000 & -3.177968823000 & -1.470937402000 \\
\hline $46 \mathrm{C}$ & -2.930879266000 & -2.072843034000 & 1.839840410000 & $46 \mathrm{C}$ & -3.046120978000 & -1.915449612000 & 1.814296221000 \\
\hline $47 \mathrm{H}$ & -2.782777209000 & -1.582003551000 & 2.812127215000 & $47 \mathrm{H}$ & -2.919127271000 & -1.436812229000 & 2.795402331000 \\
\hline $48 \mathrm{H}$ & -2.269486591000 & -2.949340862000 & 1.825595948000 & $48 \mathrm{H}$ & -2.416256343000 & -2.815095989000 & 1.817348475000 \\
\hline $49 \mathrm{H}$ & -3.977936681000 & -2.430004259000 & 1.800274464000 & $49 \mathrm{H}$ & -4.102987391000 & -2.234978837000 & 1.734084785000 \\
\hline $50 \mathrm{C}$ & -3.439587092000 & 1.069484386000 & 1.815420425000 & $50 \mathrm{C}$ & -3.375816230000 & 1.258270554000 & 1.820024837000 \\
\hline $51 \mathrm{H}$ & -4.545724150000 & 1.073911782000 & 1.771362271000 & $51 \mathrm{H}$ & -4.478192557000 & 1.335862379000 & 1.754326657000 \\
\hline $52 \mathrm{H}$ & -3.091512981000 & 2.110833485000 & 1.787791054000 & $52 \mathrm{H}$ & -2.961021238000 & 2.275037557000 & 1.810327466000 \\
\hline $53 \mathrm{H}$ & -3.147052070000 & 0.665089863100 & 2.794494635000 & $53 \mathrm{H}$ & -3.132332912000 & 0.827100924000 & 2.801233902000 \\
\hline $54 \mathrm{C}$ & -2.720429876000 & 2.159634770000 & -1.100494159000 & $54 \mathrm{C}$ & -2.585843711000 & 2.327725755000 & -1.074191927000 \\
\hline $55 \mathrm{H}$ & -2.020262807000 & 2.423856496000 & -1.907678999000 & $55 \mathrm{H}$ & -1.913818845000 & 2.543422017000 & ) -1.917979387000 \\
\hline $56 \mathrm{H}$ & -2.575483748000 & 2.904209797000 & -0.306837864500 & $56 \mathrm{H}$ & -2.348655216000 & 3.057660065000 & -0.288874733400 \\
\hline $57 \mathrm{H}$ & -3.743248668000 & 2.278947694000 & -1.508034534000 & $57 \mathrm{H}$ & -3.618698961000 & 2.518689391000 & -1.424370678000 \\
\hline$\underset{1 U}{[U}($ & ${ }_{0.000000000000}^{\left.(I I I) \mathrm{Cp}_{2}{ }_{2} \mathrm{CN}_{3}\right]^{2-}}$ & 0.000000000000 & 0.693105122500 & $\underset{1 \mathrm{U}}{[\mathrm{U}}$ & $\begin{array}{l}\left.(\mathrm{III}) \mathrm{Cp}_{2}{ }_{2} \mathrm{NCC}_{3}\right]^{2-} \\
0.00000000000\end{array}$ & 0.000000000000 & 0.664625353000 \\
\hline $2 \mathrm{~N}$ & 0.000000000000 & 0.000000000000 & 4.456691964000 & $2 c$ & 0.000000000000 & 0.000000000000 & 4.319730655000 \\
\hline $3 \mathrm{~N}$ & -0.397896091000 & 3.690327760000 & 1.515900192000 & $3 c$ & -0.387448409300 & 3.590307312000 & 1.404297020000 \\
\hline $4 C$ & 0.000000000000 & 0.000000000000 & 3.278936557000 & $4 \mathrm{~N}$ & 0.000000000000 & 0.000000000000 & 3.137208501000 \\
\hline $5 \mathrm{C}$ & -0.254902033200 & 2.536504041000 & 1.323045130000 & $5 \mathrm{~N}$ & -0.280052445400 & 2.439791998000 & 1.149287192000 \\
\hline $6 \mathrm{c}$ & 2.368842994000 & -0.921176233800 & -0.605739074300 & $6 c$ & 2.369944770000 & -0.891760090600 & -0.606668924500 \\
\hline $7 C$ & 1.976424121000 & 0.212236714200 & -1.381308185000 & $7 c$ & 1.980304733000 & 0.258166036900 & -1.361038308000 \\
\hline $8 \mathrm{C}$ & 2.148022431000 & 1.379076393000 & -0.576063082800 & $8 \mathrm{C}$ & 2.164071410000 & 1.409075622000 & -0.534932961900 \\
\hline
\end{tabular}




\begin{tabular}{|c|c|c|c|c|c|c|c|}
\hline $9 \mathrm{C}$ & 2.646523899000 & 0.965499386700 & 0.696375330900 & $9 \mathrm{C}$ & 2.651100472000 & 0.971260239100 & 0.731526509300 \\
\hline $10 \mathrm{C}$ & 2.783486533000 & -0.452699697700 & 0.678056838400 & $10 \mathrm{C}$ & 2.783244111000 & -0.448290372900 & 0.687293182600 \\
\hline $11 \mathrm{C}$ & 2.493121756000 & -2.327449838000 & -1.116241867000 & $11 \mathrm{C}$ & 2.512063446000 & -2.282511665000 & -1.151083997000 \\
\hline $12 \mathrm{H}$ & 1.756929473000 & -2.537286360000 & -1.906811341000 & $12 \mathrm{H}$ & 1.772090349000 & -2.487573038000 & -1.939912690000 \\
\hline $13 \mathrm{H}$ & 2.318651656000 & -3.064254534000 & -0.320989344100 & $13 \mathrm{H}$ & 2.356988820000 & -3.038797109000 & -0.370709183000 \\
\hline $14 \mathrm{H}$ & 3.496228466000 & -2.512212720000 & -1.548513178000 & $14 \mathrm{H}$ & 3.514094643000 & -2.441693440000 & -1.596054335000 \\
\hline $15 \mathrm{C}$ & 1.727054677000 & 0.210613090100 & -2.860127156000 & $15 \mathrm{C}$ & 1.737864494000 & 0.285648155000 & -2.841716736000 \\
\hline $16 \mathrm{H}$ & 1.079352277000 & 1.042645681000 & -3.170092250000 & $16 \mathrm{H}$ & 1.100223011000 & 1.130819928000 & -3.138835065000 \\
\hline $17 \mathrm{H}$ & 1.247166951000 & -0.718308643000 & -3.199123445000 & $17 \mathrm{H}$ & 1.249391645000 & -0.631489810800 & -3.199481124000 \\
\hline $18 \mathrm{H}$ & 2.674238336000 & 0.310463056600 & -3.428608545000 & $18 \mathrm{H}$ & 2.687728868000 & 0.386424910100 & -3.405919230000 \\
\hline $19 \mathrm{C}$ & 2.003768574000 & 2.795448616000 & -1.050808283000 & $19 \mathrm{C}$ & 2.036996262000 & 2.832018480000 & -0.991524179400 \\
\hline $20 \mathrm{H}$ & 2.936306663000 & 3.158107351000 & -1.526229732000 & $20 \mathrm{H}$ & 2.961560847000 & 3.173712719000 & -1.496276135000 \\
\hline $21 \mathrm{H}$ & 1.749241946000 & 3.473785938000 & -0.226398547800 & $21 \mathrm{H}$ & 1.829416700000 & 3.508129872000 & -0.152701927000 \\
\hline $22 \mathrm{H}$ & 1.199337394000 & 2.895438300000 & -1.795439488000 & $22 \mathrm{H}$ & 1.208775025000 & 2.961707716000 & -1.704665955000 \\
\hline $23 \mathrm{C}$ & 3.039607845000 & 1.867050548000 & 1.830940262000 & $23 \mathrm{C}$ & 3.029797979000 & 1.856227814000 & 1.883017532000 \\
\hline $24 \mathrm{H}$ & 2.890782213000 & 1.376174611000 & 2.802861891000 & $24 \mathrm{H}$ & 2.910141544000 & 1.335949993000 & 2.843519408000 \\
\hline $25 \mathrm{H}$ & 2.433863666000 & 2.782933925000 & 1.843928191000 & $25 \mathrm{H}$ & 2.392715090000 & 2.749966842000 & 1.924544408000 \\
\hline $26 \mathrm{H}$ & 4.105523584000 & 2.158486432000 & 1.762000830000 & $26 \mathrm{H}$ & 4.083743004000 & 2.187142527000 & 1.809446979000 \\
\hline $27 \mathrm{C}$ & 3.351280454000 & -1.290282041000 & 1.787255845000 & $27 \mathrm{C}$ & 3.346869970000 & -1.310371413000 & 1.779111497000 \\
\hline $28 \mathrm{H}$ & 4.457413109000 & -1.313605179000 & 1.745736130000 & $28 \mathrm{H}$ & 4.448766930000 & -1.387721653000 & 1.701942406000 \\
\hline $29 \mathrm{H}$ & 2.983213090000 & -2.322979698000 & 1.737479598000 & $29 \mathrm{H}$ & 2.927882378000 & -2.324668596000 & 1.743591448000 \\
\hline $30 \mathrm{H}$ & 3.063722520000 & -0.901022300500 & 2.774549461000 & $30 \mathrm{H}$ & 3.110855741000 & -0.905355151300 & 2.773161912000 \\
\hline $31 \mathrm{~N}$ & 0.397896091000 & -3.690327760000 & 1.515900192000 & $31 \mathrm{C}$ & 0.387448409300 & -3.590307312000 & 1.404297020000 \\
\hline $32 \mathrm{C}$ & 0.254902033200 & -2.536504041000 & 1.323045130000 & $32 \mathrm{~N}$ & 0.280052445400 & -2.439791998000 & 1.149287192000 \\
\hline $33 \mathrm{C}$ & -2.368842994000 & 0.921176233800 & -0.605739074300 & $33 \mathrm{C}$ & -2.369944770000 & 0.891760090600 & -0.606668924500 \\
\hline $34 \mathrm{C}$ & -1.976424121000 & -0.212236714200 & -1.381308185000 & $34 \mathrm{C}$ & -1.980304733000 & -0.258166036900 & -1.361038308000 \\
\hline $35 \mathrm{c}$ & -2.148022431000 & -1.379076393000 & -0.576063082800 & $35 \mathrm{C}$ & -2.164071410000 & -1.409075622000 & -0.534932961900 \\
\hline $36 \mathrm{C}$ & -2.646523899000 & -0.965499386700 & 0.696375330900 & $36 \mathrm{C}$ & -2.651100472000 & -0.971260239100 & 0.731526509300 \\
\hline $37 \mathrm{C}$ & -2.783486533000 & 0.452699697700 & 0.678056838400 & $37 \mathrm{C}$ & -2.783244111000 & 0.448290372900 & 0.687293182600 \\
\hline $38 \mathrm{C}$ & -2.493121756000 & 2.327449838000 & -1.116241867000 & $38 \mathrm{C}$ & -2.512063446000 & 2.282511665000 & -1.151083997000 \\
\hline $39 \mathrm{H}$ & -1.756929473000 & 2.537286360000 & -1.906811341000 & $39 \mathrm{H}$ & -1.772090349000 & 2.487573038000 & -1.939912690000 \\
\hline $40 \mathrm{H}$ & -2.318651656000 & 3.064254534000 & -0.320989344100 & $40 \mathrm{H}$ & -2.356988820000 & 3.038797109000 & -0.370709183000 \\
\hline $41 \mathrm{H}$ & -3.496228466000 & 2.512212720000 & -1.548513178000 & $41 \mathrm{H}$ & -3.514094643000 & 2.441693440000 & -1.596054335000 \\
\hline $42 \mathrm{C}$ & -1.727054677000 & -0.210613090100 & -2.860127156000 & $42 C$ & -1.737864494000 & -0.285648155000 & -2.841716736000 \\
\hline $43 \mathrm{H}$ & -1.079352277000 & -1.042645681000 & -3.170092250000 & $43 \mathrm{H}$ & -1.100223011000 & -1.130819928000 & -3.138835065000 \\
\hline $44 \mathrm{H}$ & -1.247166951000 & 0.718308643000 & -3.199123445000 & $44 \mathrm{H}$ & -1.249391645000 & 0.631489810800 & -3.199481124000 \\
\hline $45 \mathrm{H}$ & -2.674238336000 & -0.310463056600 & -3.428608545000 & $45 \mathrm{H}$ & -2.687728868000 & -0.386424910100 & -3.405919230000 \\
\hline $46 \mathrm{C}$ & -2.003768574000 & -2.795448616000 & -1.050808283000 & $46 C$ & -2.036996262000 & -2.832018480000 & -0.991524179400 \\
\hline $47 \mathrm{H}$ & -2.936306663000 & -3.158107351000 & -1.526229732000 & $47 \mathrm{H}$ & -2.961560847000 & -3.173712719000 & -1.496276135000 \\
\hline $48 \mathrm{H}$ & -1.749241946000 & -3.473785938000 & -0.226398547800 & $48 \mathrm{H}$ & -1.829416700000 & -3.508129872000 & -0.152701927000 \\
\hline $49 \mathrm{H}$ & -1.199337394000 & -2.895438300000 & -1.795439488000 & $49 \mathrm{H}$ & -1.208775025000 & -2.961707716000 & -1.704665955000 \\
\hline $50 \mathrm{C}$ & -3.039607845000 & -1.867050548000 & 1.830940262000 & $50 \mathrm{C}$ & -3.029797979000 & -1.856227814000 & 1.883017532000 \\
\hline $51 \mathrm{H}$ & -2.890782213000 & -1.376174611000 & 2.802861891000 & $51 \mathrm{H}$ & -2.910141544000 & -1.335949993000 & 2.843519408000 \\
\hline $52 \mathrm{H}$ & -2.433863666000 & -2.782933925000 & 1.843928191000 & $52 \mathrm{H}$ & -2.392715090000 & -2.749966842000 & 1.924544408000 \\
\hline $53 \mathrm{H}$ & -4.105523584000 & -2.158486432000 & 1.762000830000 & $53 \mathrm{H}$ & -4.083743004000 & -2.187142527000 & 1.809446979000 \\
\hline $54 \mathrm{C}$ & -3.351280454000 & 1.290282041000 & 1.787255845000 & $54 \mathrm{C}$ & -3.346869970000 & 1.310371413000 & 1.779111497000 \\
\hline $55 \mathrm{H}$ & -4.457413109000 & 1.313605179000 & 1.745736130000 & $55 \mathrm{H}$ & -4.448766930000 & 1.387721653000 & 1.701942406000 \\
\hline $56 \mathrm{H}$ & -2.983213090000 & 2.322979698000 & 1.737479598000 & $56 \mathrm{H}$ & -2.927882378000 & 2.324668596000 & 1.743591448000 \\
\hline $57 \mathrm{H}$ & -3.063722520000 & 0.901022300500 & 2.774549461000 & $57 \mathrm{H}$ & -3.110855741000 & 0.905355151300 & 2.773161912000 \\
\hline \multicolumn{2}{|c|}{ [U(IV)Cp* $\left.{ }_{2} \mathrm{CN}_{3}\right]$} & (1) & ה & \multicolumn{4}{|c|}{$\left[\mathrm{U}(\mathrm{IV}) \mathrm{Cp}^{*}{ }_{2} \mathrm{NC}_{3}\right]^{1-}$} \\
\hline $1 \mathrm{U}$ & & 0.000000000000 & 0.498247659300 & 10 & 0.000000000000 & 0.000000000000 & 0.530890778500 \\
\hline $2 \mathrm{~N}$ & -0.006121805906 & -3.596980631000 & 1.269106245000 & $2 c$ & 0.012301319410 & -3.545588480000 & 1.061853406000 \\
\hline $3 \mathrm{~N}$ & 0.000000000000 & 0.000000000000 & 4.171972244000 & $3 \mathrm{C}$ & 0.000000000000 & 0.000000000000 & 4.081818081000 \\
\hline $4 N$ & 0.006121805906 & 3.596980631000 & 1.269106245000 & & 0.000000000000 & 35455800000 & 4.001010000000 \\
\hline $5 \mathrm{C}$ & -0.009639042411 & -2.439685628000 & 1.059658680000 & $4 \mathrm{C}$ & -0.012301319410 & 3.545588480000 & 1.061853406000 \\
\hline $6 c$ & 0.000000000000 & 0.000000000000 & 2.997217064000 & $5 \mathrm{~N}$ & 0.003140854492 & -2.383955272000 & 0.828748276200 \\
\hline $7 c$ & 0.009639042411 & 2.439685628000 & 1.059658680000 & $6 \mathrm{~N}$ & 0.000000000000 & 0.000000000000 & 2.896467294000 \\
\hline $8 \mathrm{C}$ & -2.667769700000 & 0.712457745500 & 0.745934941600 & $7 \mathrm{~N}$ & -0.003140854492 & 2.383955272000 & 0.828748276200 \\
\hline $9 \mathrm{c}$ & -2.668050356000 & -0.714247608400 & 0.730830216300 & $8 \mathrm{C}$ & -2.657116844000 & 0.719974661500 & 0.770092334400 \\
\hline $10 \mathrm{c}$ & -2.275947090000 & -1.143844297000 & -0.573170776300 & $9 \mathrm{C}$ & -2.658319790000 & -0.708038772100 & 0.777365803700 \\
\hline $11 \mathrm{C}$ & -2.019662334000 & 0.021287448080 & -1.361539616000 & $10 \mathrm{C}$ & -2.316890683000 & -1.154846233000 & -0.537087348300 \\
\hline $12 \mathrm{C}$ & -2.276253382000 & 1.169769389000 & -1.361539616000 & $11 \mathrm{C}$ & -2.077947405000 & -0.005562485418 & -1.347685065000 \\
\hline $13 c$ & -3.109315756000 & 1.567249268000 & -0.548906811300 & $12 \mathrm{C}$ & -2.314772174000 & 1.152357206000 & -0.549290486600 \\
\hline 10 & $-3.109313 / 56000$ & 1.567249268000 & 1.896421385000 & $13 \mathrm{C}$ & -3.077674098000 & 1.600039448000 & 1.908817966000 \\
\hline $14 \mathrm{H}$ & -4.207119027000 & 1.682650979000 & 1.890345956000 & $14 \mathrm{H}$ & -4.171481773000 & 1.749516208000 & 1.901360640000 \\
\hline $15 \mathrm{H}$ & -2.658040153000 & 2.565864142000 & 1.855182271000 & $15 \mathrm{H}$ & -2.596923398000 & 2.584762020000 & 1.856004983000 \\
\hline $16 \mathrm{H}$ & -2.826465783000 & 1.124382182000 & 2.860664679000 & $16 \mathrm{H}$ & -2.807602339000 & 1.160744176000 & 2.877877024000 \\
\hline $17 \mathrm{C}$ & -3.110530665000 & -1.592779751000 & 1.862876005000 & $17 \mathrm{C}$ & -3.080251472000 & -1.576936010000 & 1.923845886000 \\
\hline $18 \mathrm{H}$ & -2.817501567000 & -1.176304580000 & 2.835698150000 & - & 2846473903000 & & \\
\hline $19 \mathrm{H}$ & -2.669213834000 & -2.594263470000 & 1.794874757000 & $18 \mathrm{H}$ & -2.846473903000 & -1.109629338000 & 2.889053509000 \\
\hline $20 \mathrm{H}$ & -4.209326609000 & -1.697590965000 & 1.861140125000 & $19 \mathrm{H}$ & -2.570447974000 & -2.548297252000 & 1.902850304000 \\
\hline $21 \mathrm{c}$ & -2.324782642000 & & & $20 \mathrm{H}$ & -4.168670305000 & -1.758999353000 & 1.893938093000 \\
\hline $21 \mathrm{C}$ & $-2.324 / 82042000$ & $-2.34 / 910331000$ & $-1.09 / 389569000$ & $21 \mathrm{C}$ & -2.407735286000 & -2.559213812000 & -1.050313443000 \\
\hline
\end{tabular}




\begin{tabular}{|c|c|c|c|c|c|c|c|}
\hline $22 \mathrm{H}$ & -3.296189704000 & -2.737472924000 & -1.587310447000 & & & -2704123019000 & \\
\hline $23 \mathrm{H}$ & -2.188837746000 & -3.285727271000 & -0.298752673300 & $22 \mathrm{H}$ & -3.366636630000 & -2.704123019000 & $-1.5 / 8 / 14393000$ \\
\hline $24 \mathrm{H}$ & -1.541846946000 & -2.739980285000 & -1.844823252000 & $23 \mathrm{H}$ & -2.346689957000 & -3.293110021000 & -0.239695619500 \\
\hline $25 \mathrm{C}$ & -1.795823978000 & 0.038190528340 & -2.845315079000 & $24 \mathrm{H}$ & -1.602857477000 & -2.800192006000 & -1.758591963000 \\
\hline $26 \mathrm{H}$ & -1.246112610000 & -0.847171464300 & -3.192166812000 & $25 \mathrm{C}$ & -1.853483917000 & -0.013989423750 & -2.830915273000 \\
\hline $27 \mathrm{H}$ & -1.236040911000 & 0.925774336600 & -3.170476317000 & $26 \mathrm{H}$ & -1.290312087000 & -0.898607150200 & -3.158042188000 \\
\hline $28 \mathrm{H}$ & -2.759127166000 & 0.050792277940 & -3.386303545000 & $27 \mathrm{H}$ & -1.304583077000 & 0.875102772200 & -3.169780338000 \\
\hline $29 \mathrm{C}$ & -2.332184466000 & 2.583892064000 & -1.044242142000 & $28 \mathrm{H}$ & -2.814059476000 & -0.025472879730 & -3.377141667000 \\
\hline $30 \mathrm{H}$ & -1.545072981000 & 2.799171998000 & -1.780269176000 & $29 \mathrm{C}$ & -2.398653819000 & 2.551669350000 & -1.077650250000 \\
\hline $31 \mathrm{H}$ & -2.208236675000 & 3.305334660000 & -0.228740314500 & $30 \mathrm{H}$ & -1.589873781000 & 2.782296804000 & -1.784893325000 \\
\hline $32 \mathrm{H}$ & -3.301726522000 & 2.775655072000 & -1.537050363000 & $31 \mathrm{H}$ & -2.338065400000 & 3.294014941000 & -0.274711533100 \\
\hline $33 \mathrm{C}$ & 2.667769700000 & -0.712457745500 & 0.745934941600 & $32 \mathrm{H}$ & -3.354547996000 & 2.694731973000 & -1.611881410000 \\
\hline $34 \mathrm{C}$ & 2.276253382000 & -1.169769389000 & -0.548906811300 & $33 \mathrm{c}$ & 2.657116844000 & -0.719974661500 & 0.770092334400 \\
\hline $35 \mathrm{c}$ & 2.019662334000 & -0.021287448080 & -1.361539616000 & $34 \mathrm{C}$ & 2.314772174000 & -1.152357206000 & -0.549290486600 \\
\hline $36 \mathrm{C}$ & 2.275947090000 & 1.143844297000 & -0.573170776300 & $35 \mathrm{C}$ & 2.077947405000 & 0.005562485418 & -1.347685065000 \\
\hline $37 \mathrm{C}$ & 2.668050356000 & 0.714247608400 & 0.730830216300 & $36 \mathrm{C}$ & 2.316890683000 & 1.154846233000 & -0.537087348300 \\
\hline $38 \mathrm{C}$ & 3.109315756000 & -1.567249268000 & 1.896421385000 & $37 \mathrm{C}$ & 2.658319790000 & $\begin{array}{c}0.708038772100 \\
-1.600039448000\end{array}$ & 0.777365803700 \\
\hline $39 \mathrm{H}$ & 4.207119027000 & -1.682650979000 & 1.890345956000 & $38 \mathrm{C}$ & 3.077674098000 & -1.600039448000 & 1.908817966000 \\
\hline $40 \mathrm{H}$ & 2.658040153000 & -2.565864142000 & 1.855182271000 & $39 \mathrm{H}$ & 2.596923398000 & -2.584762020000 & 1.901360640000 \\
\hline $41 \mathrm{H}$ & 2.826465783000 & -1.124382182000 & 2.860664679000 & 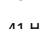 & 2.807602339000 & -1.160744176000 & 2.877877024000 \\
\hline $42 \mathrm{C}$ & 2.332184466000 & -2.583892064000 & -1.044242142000 & $41 \mathrm{H}$ & $2.80 / 602339000$ & -1.10014410000 & $2.87 / 87 / 7024000$ \\
\hline $43 \mathrm{H}$ & 3.301726522000 & -2.775655072000 & -1.537050363000 & $42 \mathrm{C}$ & 2.398653819000 & -2.551669350000 & -1.077650250000 \\
\hline $44 \mathrm{H}$ & 1.545072981000 & -2.799171998000 & -1.780269176000 & $43 \mathrm{H}$ & 3.354547996000 & -2.694731973000 & -1.611881410000 \\
\hline $45 \mathrm{H}$ & 2.208236675000 & -3.305334660000 & -0.228740314500 & $44 \mathrm{H}$ & 1.589873781000 & -2.782296804000 & -1.784893325000 \\
\hline $46 \mathrm{C}$ & 1.795823978000 & -0.038190528340 & -2.845315079000 & $45 \mathrm{H}$ & 2.338065400000 & -3.294014941000 & -0.274711533100 \\
\hline $47 \mathrm{H}$ & 2.759127166000 & -0.050792277940 & -3.386303545000 & $46 \mathrm{C}$ & 1.853483917000 & 0.013989423750 & -2.830915273000 \\
\hline $48 \mathrm{H}$ & 1.246112610000 & 0.847171464300 & -3.192166812000 & $47 \mathrm{H}$ & 2.814059476000 & 0.025472879730 & -3.377141667000 \\
\hline $49 \mathrm{H}$ & 1.236040911000 & -0.925774336600 & -3.170476317000 & $48 \mathrm{H}$ & 1.290312087000 & 0.898607150200 & -3.158042188000 \\
\hline $50 \mathrm{C}$ & 2.324782642000 & 2.547916531000 & -1.097389569000 & $49 \mathrm{H}$ & 1.304583077000 & -0.875102772200 & -3.169780338000 \\
\hline $51 \mathrm{H}$ & 3.296189704000 & 2.737472924000 & -1.587310447000 & $50 \mathrm{C}$ & 2.407735286000 & 2.559213812000 & -1.050313443000 \\
\hline $52 \mathrm{H}$ & 2.188837746000 & 3.285727271000 & -0.298752673300 & $51 \mathrm{H}$ & 3.366636630000 & 2.704123019000 & -1.578714393000 \\
\hline $53 \mathrm{H}$ & 1.541846946000 & 2.739980285000 & -1.844823252000 & $52 \mathrm{H}$ & 2.346689957000 & 3.293110021000 & -0.239695619500 \\
\hline $54 \mathrm{C}$ & 3.110530665000 & 1.592779751000 & 1.862876005000 & $53 \mathrm{H}$ & 1.602857477000 & 2.800192006000 & -1.758591963000 \\
\hline $55 \mathrm{H}$ & 2.817501567000 & 1.176304580000 & 2.835698150000 & $54 \mathrm{C}$ & 3.080251472000 & 1.576936010000 & 1.923845886000 \\
\hline $56 \mathrm{H}$ & 2.669213834000 & 2.594263470000 & 1.794874757000 & $55 \mathrm{H}$ & 2.846473903000 & 1.109629338000 & 2.889053509000 \\
\hline $57 \mathrm{H}$ & 4.209326609000 & 1.697590965000 & 1.861140125000 & $56 \mathrm{H}$ & 2.570447974000 & 2.548297252000 & 1.902850304000 \\
\hline & & & & $57 \mathrm{H}$ & 4.168670305000 & 1.758999353000 & 1.893938093000 \\
\hline \multicolumn{8}{|c|}{$\left[\mathrm{MN}^{*}{ }_{2} \mathrm{X}_{3}\right]^{q} / \mathrm{q}=2-, 1-/ \mathrm{X}=\mathrm{CN}, \mathrm{NC} \quad / \mathrm{GAZ}$} \\
\hline $\begin{array}{l}{[\mathrm{Ce}} \\
1 \mathrm{Ce}\end{array}$ & $\underset{13.490106620000}{\left.(\mathrm{III}) \mathbf{N}^{*}{ }_{2} \mathbf{C N}_{\mathbf{3}}\right]^{2-}}$ & 22.521990030000 & 0.130086868000 & $\begin{array}{l}{[\mathrm{Ce}} \\
1 \mathrm{Ce}\end{array}$ & $\frac{\left.(\mathrm{III}) \mathrm{N}_{2}{ }_{2} \mathrm{NC}_{3}\right]^{2-}}{13.466098780000}$ & 22.519003230000 & 0.156744398900 \\
\hline $2 \mathrm{Si}$ & 16.183970060000 & 24.031669560000 & 1.867627026000 & $2 \mathrm{Si}$ & 16.202908360000 & 24.024249040000 & 1.862358691000 \\
\hline $3 \mathrm{Si}$ & 16.000453060000 & 24.858052630000 & -1.036970627000 & $3 \mathrm{Si}$ & 15.997065980000 & 24.865717960000 & -1.024682780000 \\
\hline $4 \mathrm{Si}$ & 11.569644710000 & 20.979705460000 & -2.409344487000 & $4 \mathrm{Si}$ & 11.553493270000 & 20.974560370000 & -2.412704224000 \\
\hline $5 \mathrm{Si}$ & 14.431817110000 & 20.009631850000 & -2.320757126000 & $5 \mathrm{Si}$ & 14.409736670000 & 20.007919270000 & -2.300370781000 \\
\hline $6 \mathrm{c}$ & 14.608299590000 & 20.486856770000 & 1.490309387000 & $6 \mathrm{~N}$ & 14.524235740000 & 20.592630810000 & 1.420146387000 \\
\hline $7 \mathrm{C}$ & 11.685862530000 & 22.601184380000 & 2.024665652000 & $7 \mathrm{~N}$ & 11.746333320000 & 22.631010720000 & 1.920673239000 \\
\hline $8 \mathrm{C}$ & 12.180530040000 & 24.589817230000 & -0.990801766500 & $8 \mathrm{~N}$ & 12.289375080000 & 24.459234590000 & -0.970115351800 \\
\hline $9 \mathrm{~N}$ & 15.442192240000 & 23.927297210000 & 0.307092500100 & $9 \mathrm{~N}$ & 15.445746030000 & 23.919774630000 & 0.311563038000 \\
\hline $10 \mathrm{~N}$ & 13.166854510000 & 21.035876060000 & -1.744084474000 & $10 \mathrm{~N}$ & 13.140988870000 & 21.030997440000 & -1.729664804000 \\
\hline $11 \mathrm{~N}$ & 15.120157300000 & 19.575999270000 & 2.031710109000 & $11 \mathrm{C}$ & 14.958356150000 & 19.654137750000 & 1.994709667000 \\
\hline $12 \mathrm{~N}$ & 10.870267570000 & 22.629245990000 & 2.871789423000 & $12 \mathrm{C}$ & 10.921811340000 & 22.684377160000 & 2.767911719000 \\
\hline $13 \mathrm{~N}$ & 11.654547110000 & 25.505325190000 & -1.510362883000 & $13 \mathrm{C}$ & 11.751158850000 & 25.400367520000 & -1.443529654000 \\
\hline $14 \mathrm{C}$ & 14.968927980000 & 23.564149590000 & 3.242300904000 & $14 \mathrm{C}$ & 15.018705030000 & 23.525188870000 & 3.253836382000 \\
\hline $15 \mathrm{H}$ & 14.075454980000 & 24.205785870000 & 3.257827189000 & $15 \mathrm{H}$ & 14.108578690000 & 24.142866800000 & 3.278353814000 \\
\hline $16 \mathrm{H}$ & 15.473633220000 & 23.672297340000 & 4.217356126000 & $16 \mathrm{H}$ & 15.532077720000 & 23.652253430000 & 4.222054591000 \\
\hline $17 \mathrm{H}$ & 14.632029430000 & 22.518055830000 & 3.176960965000 & $17 \mathrm{H}$ & 14.710751330000 & 22.470967180000 & 3.191098854000 \\
\hline $18 \mathrm{C}$ & 16.799336890000 & 25.784694750000 & 2.334174613000 & $18 \mathrm{C}$ & 16.792925900000 & 25.783871150000 & 2.341035436000 \\
\hline $19 \mathrm{H}$ & 17.575395600000 & 26.163449470000 & 1.652083936000 & $19 \mathrm{H}$ & 17.547954600000 & 26.188210970000 & 1.650208060000 \\
\hline $20 \mathrm{H}$ & 17.229854790000 & 25.762303000000 & 3.349581831000 & $20 \mathrm{H}$ & 17.241844080000 & 25.758531200000 & 3.348446402000 \\
\hline $21 \mathrm{H}$ & 15.969138580000 & 26.506817850000 & 2.336243794000 & $21 \mathrm{H}$ & 15.947557770000 & 26.487979150000 & 2.366539423000 \\
\hline $22 \mathrm{C}$ & 17.692250120000 & 22.887038500000 & 2.048232925000 & $22 \mathrm{C}$ & 17.735930820000 & 22.906155160000 & 2.017799619000 \\
\hline $23 \mathrm{H}$ & 17.377856760000 & 21.838449770000 & 1.935614470000 & $23 \mathrm{H}$ & 17.443309590000 & 21.854857540000 & 1.877097928000 \\
\hline $24 \mathrm{H}$ & 18.159969350000 & 22.997066110000 & 3.040931610000 & $24 \mathrm{H}$ & 18.201022110000 & 22.999565750000 & 3.013428973000 \\
\hline $25 \mathrm{H}$ & 18.454768920000 & 23.100921560000 & 1.284058291000 & $25 \mathrm{H}$ & 18.494340460000 & 23.154423600000 & 1.260103933000 \\
\hline $26 \mathrm{C}$ & 15.568923480000 & 26.707623750000 & -0.922181641900 & $26 \mathrm{C}$ & 15.513286660000 & 26.703524490000 & -0.912934310300 \\
\hline $27 \mathrm{H}$ & 14.476536370000 & 26.822435220000 & -0.853927899600 & $27 \mathrm{H}$ & 14.417308250000 & 26.790587680000 & -0.859569545900 \\
\hline $28 \mathrm{H}$ & 15.911769390000 & 27.245173160000 & -1.822140483000 & $28 \mathrm{H}$ & 15.855975610000 & 27.254388950000 & -1.805026826000 \\
\hline $29 \mathrm{H}$ & 16.023880640000 & 27.188378010000 & -0.044317531080 & $29 \mathrm{H}$ & 15.943039300000 & 27.191018610000 & -0.025534835790 \\
\hline $30 \mathrm{c}$ & 17.898015150000 & 24.760233380000 & -1.279242689000 & $30 \mathrm{C}$ & 17.901455220000 & 24.827309250000 & -1.242809859000 \\
\hline $31 \mathrm{H}$ & 18.449094280000 & 25.156375750000 & -0.412481745200 & $31 \mathrm{H}$ & 18.434450870000 & 25.239416950000 & -0.372316266100 \\
\hline $32 \mathrm{H}$ & 18.205144820000 & 25.341487160000 & -2.164931301000 & $32 \mathrm{H}$ & 18.196908810000 & 25.418768620000 & -2.126000465000 \\
\hline
\end{tabular}




\begin{tabular}{|c|c|c|c|c|c|c|c|}
\hline $33 \mathrm{H}$ & 18.219074290000 & 23.717954720000 & -1.429129147000 & $33 \mathrm{H}$ & 18.255316770000 & 23.795447110000 & -1.392609522000 \\
\hline $34 \mathrm{C}$ & 15.251289010000 & 24.281973060000 & -2.681458937000 & $34 \mathrm{C}$ & 15.307324020000 & 24.270609030000 & -2.688530971000 \\
\hline $35 \mathrm{H}$ & 15.443209750000 & 23.223961320000 & -2.904976551000 & $35 \mathrm{H}$ & 15.586655690000 & 23.235182310000 & -2.927748454000 \\
\hline $36 \mathrm{H}$ & 15.691449430000 & 24.877996950000 & -3.498520421000 & $36 \mathrm{H}$ & 15.709507300000 & 24.915739200000 & -3.487993117000 \\
\hline $37 \mathrm{H}$ & 14.164089590000 & 24.446437410000 & -2.702862778000 & $37 \mathrm{H}$ & 14.211202090000 & 24.348730390000 & -2.719686415000 \\
\hline $38 \mathrm{C}$ & 10.980229670000 & 19.227371550000 & -2.910378424000 & $38 \mathrm{C}$ & 10.970202050000 & 19.220150180000 & -2.917387932000 \\
\hline $39 \mathrm{H}$ & 11.603087170000 & 18.772497470000 & -3.695238988000 & $39 \mathrm{H}$ & 11.603555590000 & 18.763613280000 & -3.692962506000 \\
\hline $40 \mathrm{H}$ & 9.948231816000 & 19.285955500000 & -3.295703389000 & $40 \mathrm{H}$ & 9.943170421000 & 19.276427640000 & -3.316280682000 \\
\hline $41 \mathrm{H}$ & 10.978096200000 & 18.548577370000 & -2.044403772000 & $41 \mathrm{H}$ & 10.957942490000 & 18.543380920000 & -2.049731922000 \\
\hline $42 C$ & 11.380122100000 & 22.056429070000 & -3.966069510000 & $42 \mathrm{C}$ & 11.375593310000 & 22.044936090000 & -3.976063569000 \\
\hline $43 \mathrm{H}$ & 11.568247570000 & 23.110722810000 & -3.712900569000 & $43 \mathrm{H}$ & 11.570123310000 & 23.099069150000 & -3.727570095000 \\
\hline $44 \mathrm{H}$ & 10.360610780000 & 21.983652150000 & -4.380267658000 & $44 \mathrm{H}$ & 10.357226700000 & 21.975816070000 & -4.393693540000 \\
\hline $45 \mathrm{H}$ & 12.091361990000 & 21.759734290000 & -4.751553127000 & $45 \mathrm{H}$ & 12.088069450000 & 21.740050180000 & -4.757274189000 \\
\hline $46 \mathrm{C}$ & 10.280286310000 & 21.585665330000 & -1.162540074000 & $46 \mathrm{C}$ & 10.245259660000 & 21.579576030000 & -1.183834044000 \\
\hline $47 \mathrm{H}$ & 10.274730200000 & 20.998053400000 & -0.232573943400 & $47 \mathrm{H}$ & 10.235996410000 & 20.994015890000 & -0.252533786800 \\
\hline $48 \mathrm{H}$ & 9.278347138000 & 21.498952650000 & -1.616228020000 & $48 \mathrm{H}$ & 9.248533407000 & 21.483904120000 & -1.647089275000 \\
\hline $49 \mathrm{H}$ & 10.411692990000 & 22.644717150000 & -0.891713034300 & $49 \mathrm{H}$ & 10.371795790000 & 22.638806240000 & -0.914561003600 \\
\hline $50 \mathrm{C}$ & 14.579848920000 & 20.001362430000 & -4.230931745000 & $50 \mathrm{C}$ & 14.570017850000 & 20.003926100000 & -4.210492384000 \\
\hline $51 \mathrm{H}$ & 13.668076340000 & 19.623558200000 & -4.718578077000 & $51 \mathrm{H}$ & 13.665574120000 & 19.618818320000 & -4.706088416000 \\
\hline $52 \mathrm{H}$ & 15.419373820000 & 19.360957240000 & -4.550053266000 & $52 \mathrm{H}$ & 15.418016520000 & 19.372364380000 & -4.524793764000 \\
\hline $53 \mathrm{H}$ & 14.764213880000 & 21.017315990000 & -4.612512126000 & $53 \mathrm{H}$ & 14.747775610000 & 21.022748950000 & -4.587833060000 \\
\hline $54 \mathrm{C}$ & 14.243487960000 & 18.191602660000 & -1.791657411000 & $54 \mathrm{C}$ & 14.222260100000 & 18.185171360000 & -1.781308826000 \\
\hline $55 \mathrm{H}$ & 14.230596640000 & 18.131635670000 & -0.692832765500 & $55 \mathrm{H}$ & 14.203222490000 & 18.117780970000 & -0.683015324000 \\
\hline $56 \mathrm{H}$ & 15.092898840000 & 17.589368350000 & -2.155180181000 & $56 \mathrm{H}$ & 15.074038610000 & 17.585940270000 & -2.144626239000 \\
\hline $57 \mathrm{H}$ & 13.317118320000 & 17.739883880000 & -2.174374335000 & $57 \mathrm{H}$ & 13.297954170000 & 17.734544500000 & -2.170831618000 \\
\hline $58 \mathrm{C}$ & 16.140837760000 & 20.532277690000 & -1.686343719000 & $58 \mathrm{C}$ & 16.117992670000 & 20.525028540000 & -1.659497078000 \\
\hline $59 \mathrm{H}$ & 16.415280920000 & 21.558511860000 & -1.965910813000 & $59 \mathrm{H}$ & 16.393378620000 & 21.552855750000 & -1.932562829000 \\
\hline $60 \mathrm{H}$ & 16.899544910000 & 19.857423320000 & -2.117169797000 & $60 \mathrm{H}$ & 16.876538500000 & 19.851873880000 & -2.093538856000 \\
\hline $61 \mathrm{H}$ & 16.205180490000 & 20.443959840000 & -0.592038388900 & $61 \mathrm{H}$ & 16.178334010000 & 20.433524310000 & -0.565709433600 \\
\hline \multicolumn{4}{|c|}{$\left[\mathrm{U}(\mathrm{III}) \mathrm{N} *{ }_{2} \mathrm{CN}_{3}\right]^{2-}$} & \multicolumn{4}{|c|}{$\left[\mathrm{U}(\mathrm{III}) \mathrm{N} *{ }_{2} \mathrm{NC}_{3}\right]^{2-}$} \\
\hline $2 \mathrm{Si}$ & 10.886976370000 & 9.675800247000 & 2.439903953000 & $2 \mathrm{Si}$ & 10.864918380000 & 9.655939107000 & 2.443029080000 \\
\hline $3 \mathrm{Si}$ & 7.988545376000 & 9.718245472000 & 3.321013915000 & $3 \mathrm{Si}$ & 7.978844037000 & 9.768608085000 & 3.332980513000 \\
\hline $4 \mathrm{Si}$ & 12.295229180000 & 8.288082051000 & 7.336557932000 & $4 \mathrm{Si}$ & 12.278679690000 & 8.260311010000 & 7.335784161000 \\
\hline $5 \mathrm{Si}$ & 12.469356030000 & 5.409775118000 & 6.411824719000 & $5 \mathrm{Si}$ & 12.490135410000 & 5.384883170000 & 6.426952779000 \\
\hline $6 \mathrm{~N}$ & 11.602668170000 & 5.417610807000 & 2.017356773000 & $6 \mathrm{C}$ & 11.449234590000 & 5.421042793000 & 2.110827894000 \\
\hline $7 \mathrm{~N}$ & 7.239924675000 & 4.563263773000 & 5.051036423000 & $7 c$ & 7.340282422000 & 4.581213136000 & 4.861991834000 \\
\hline $8 \mathrm{~N}$ & 8.031916513000 & 8.877748319000 & 7.773417763000 & $8 \mathrm{C}$ & 8.009716864000 & 8.707257677000 & 7.646615481000 \\
\hline $9 \mathrm{~N}$ & 9.598507450000 & 9.075952960000 & 3.431636829000 & $9 \mathrm{~N}$ & 9.566858336000 & 9.077103083000 & 3.432693486000 \\
\hline $10 \mathrm{~N}$ & 11.756021680000 & 6.991958200000 & 6.318685332000 & $10 \mathrm{~N}$ & 11.744628510000 & 6.948854107000 & 6.339396215000 \\
\hline $11 \mathrm{C}$ & 11.058883660000 & 5.961620942000 & 2.909270893000 & $11 \mathrm{~N}$ & 10.983655200000 & 5.999356907000 & 3.034945521000 \\
\hline $12 \mathrm{C}$ & 8.065685108000 & 5.401268862000 & 5.000409349000 & $12 \mathrm{~N}$ & 8.162999523000 & 5.432470024000 & 4.863120685000 \\
\hline $13 \mathrm{C}$ & 8.550806667000 & 8.350282651000 & 6.856958208000 & $13 \mathrm{~N}$ & 8.612350638000 & 8.266425377000 & 6.725793201000 \\
\hline $14 \mathrm{C}$ & 10.974194920000 & 11.589510660000 & 2.419840142000 & $14 \mathrm{C}$ & 10.995616850000 & 11.567895490000 & 2.422744965000 \\
\hline $15 \mathrm{H}$ & 11.121156060000 & 11.982636800000 & 3.437404900000 & $15 \mathrm{H}$ & 11.156651270000 & 11.956905990000 & 3.440115077000 \\
\hline $16 \mathrm{H}$ & 10.059612840000 & 12.048602790000 & 2.014084414000 & $16 \mathrm{H}$ & 10.091886100000 & 12.050094150000 & 2.020099364000 \\
\hline $17 \mathrm{H}$ & 11.821582660000 & 11.927125010000 & 1.799697953000 & $17 \mathrm{H}$ & 11.849776850000 & 11.883973380000 & 1.799798166000 \\
\hline $18 \mathrm{C}$ & 10.762649740000 & 9.120227653000 & 0.625053507100 & $18 \mathrm{C}$ & 10.731178910000 & 9.105100283000 & 0.627476298600 \\
\hline $19 \mathrm{H}$ & 11.616577250000 & 9.503774500000 & 0.041793893470 & $19 \mathrm{H}$ & 11.588717570000 & 9.475518206000 & 0.040996553100 \\
\hline $20 \mathrm{H}$ & 9.837230063000 & 9.467069318000 & 0.143111957300 & $20 \mathrm{H}$ & 9.809261594000 & 9.467837647000 & 0.150672302400 \\
\hline $21 \mathrm{H}$ & 10.787204090000 & 8.020548999000 & 0.580820469800 & $21 \mathrm{H}$ & 10.736465750000 & 8.005469083000 & 0.580779930500 \\
\hline $22 \mathrm{C}$ & 12.604479730000 & 9.110591153000 & 3.011435499000 & $22 \mathrm{C}$ & 12.573775630000 & 9.067089666000 & 3.018001768000 \\
\hline $23 \mathrm{H}$ & 12.834938190000 & 9.401007398000 & 4.045092749000 & $23 \mathrm{H}$ & 12.833968700000 & 9.422425732000 & 4.024390106000 \\
\hline $24 \mathrm{H}$ & 13.363847550000 & 9.573027928000 & 2.357606895000 & $24 \mathrm{H}$ & 13.332435780000 & 9.458974327000 & 2.318540294000 \\
\hline $25 \mathrm{H}$ & 12.711945460000 & 8.019806302000 & 2.929423796000 & $25 \mathrm{H}$ & 12.648557680000 & 7.970463954000 & 3.008290122000 \\
\hline $26 \mathrm{C}$ & 7.459677648000 & 10.211000840000 & 1.546099335000 & $26 \mathrm{C}$ & 7.464558171000 & 10.300177420000 & 1.563997034000 \\
\hline $27 \mathrm{H}$ & 8.088094371000 & 11.001224450000 & 1.108993647000 & $27 \mathrm{H}$ & 8.124132922000 & 11.067177560000 & 1.130865838000 \\
\hline $28 \mathrm{H}$ & 6.421718659000 & 10.584043570000 & 1.569014770000 & $28 \mathrm{H}$ & 6.443191157000 & 10.716180060000 & 1.594054513000 \\
\hline $29 \mathrm{H}$ & 7.488766898000 & 9.342360429000 & 0.871043788200 & $29 \mathrm{H}$ & 7.455437998000 & 9.437073710000 & 0.881339882300 \\
\hline $30 \mathrm{C}$ & 7.751521257000 & 11.273796890000 & 4.388446754000 & $30 \mathrm{C}$ & 7.792885756000 & 11.322395350000 & 4.415217856000 \\
\hline $31 \mathrm{H}$ & 7.902729238000 & 11.020432290000 & 5.448600948000 & $31 \mathrm{H}$ & 7.954747913000 & 11.058448350000 & 5.471198736000 \\
\hline $32 \mathrm{H}$ & 6.732263481000 & 11.680013630000 & 4.276882442000 & $32 \mathrm{H}$ & 6.782446512000 & 11.754781610000 & 4.322690981000 \\
\hline $33 \mathrm{H}$ & 8.467178778000 & 12.064719930000 & 4.117992211000 & $33 \mathrm{H}$ & 8.524109404000 & 12.096916430000 & 4.138699513000 \\
\hline $34 \mathrm{C}$ & 6.683532848000 & 8.463154380000 & 3.868964124000 & $34 \mathrm{C}$ & 6.629610730000 & 8.554156659000 & 3.867919867000 \\
\hline $35 \mathrm{H}$ & 6.667800543000 & 7.565398086000 & 3.234337637000 & $35 \mathrm{H}$ & 6.620480341000 & 7.642910714000 & 3.251964685000 \\
\hline $36 \mathrm{H}$ & 5.688889096000 & 8.938415864000 & 3.807476946000 & $36 \mathrm{H}$ & 5.646112249000 & 9.045055988000 & 3.762963436000 \\
\hline $37 \mathrm{H}$ & 6.811763174000 & 8.133020203000 & 4.911316078000 & $37 \mathrm{H}$ & 6.728712541000 & 8.248109647000 & 4.919570303000 \\
\hline $38 \mathrm{C}$ & 14.203063480000 & 8.455312279000 & 7.369952233000 & $38 \mathrm{C}$ & 14.185111000000 & 8.457786813000 & 7.358781077000 \\
\hline $39 \mathrm{H}$ & 14.699210880000 & 7.555074008000 & 7.763452891000 & $39 \mathrm{H}$ & 14.697552100000 & 7.569944219000 & 7.759323255000 \\
\hline $40 \mathrm{H}$ & 14.500225830000 & 9.306346244000 & 8.005799677000 & $40 \mathrm{H}$ & 14.470877870000 & 9.320141099000 & 7.984616152000 \\
\hline $41 \mathrm{H}$ & 14.595098960000 & 8.636278250000 & 6.357322464000 & $41 \mathrm{H}$ & 14.569604120000 & 8.635111627000 & 6.342296132000 \\
\hline
\end{tabular}




\begin{tabular}{|c|c|c|c|c|c|c|c|}
\hline $42 \mathrm{C}$ & 11.730087100000 & 8.109861088000 & 9.142685905000 & $42 \mathrm{C}$ & 11.732040630000 & 8.096269392000 & 9.151303571000 \\
\hline $43 \mathrm{H}$ & 10.629975370000 & 8.097805299000 & 9.176936668000 & $43 \mathrm{H}$ & 10.632794710000 & 8.057727882000 & 9.197390146000 \\
\hline $44 \mathrm{H}$ & 12.080644930000 & 8.963059384000 & 9.747364409000 & $44 \mathrm{H}$ & 12.067652000000 & 8.965756880000 & 9.741309173000 \\
\hline $45 \mathrm{H}$ & 12.102386610000 & 7.185991631000 & 9.607952370000 & $45 \mathrm{H}$ & 12.130798940000 & 7.187621685000 & 9.625526499000 \\
\hline $46 \mathrm{C}$ & 11.666583820000 & 9.990972253000 & 6.788619355000 & $46 \mathrm{C}$ & 11.624998340000 & 9.949587565000 & 6.774545114000 \\
\hline $47 \mathrm{H}$ & 11.985872460000 & 10.264256750000 & 5.773807291000 & $47 \mathrm{H}$ & 11.941404280000 & 10.219203740000 & 5.757344589000 \\
\hline $48 \mathrm{H}$ & 12.066566770000 & 10.751499210000 & 7.481842846000 & $48 \mathrm{H}$ & 12.013837680000 & 10.721060270000 & 7.461715818000 \\
\hline $49 \mathrm{H}$ & 10.569376230000 & 10.047410030000 & 6.832634028000 & $49 \mathrm{H}$ & 10.526771960000 & 9.989357699000 & 6.815505182000 \\
\hline $50 \mathrm{C}$ & 14.040656520000 & 5.259492296000 & 5.351150797000 & $50 \mathrm{C}$ & 14.045339410000 & 5.257707529000 & 5.338175740000 \\
\hline $51 \mathrm{H}$ & 13.784575530000 & 5.409747127000 & 4.291495301000 & $51 \mathrm{H}$ & 13.771438830000 & 5.408278979000 & 4.282976061000 \\
\hline $52 \mathrm{H}$ & 14.495735350000 & 4.260133720000 & 5.453770778000 & $52 \mathrm{H}$ & 14.517056390000 & 4.264899606000 & 5.430322863000 \\
\hline $53 \mathrm{H}$ & 14.794250500000 & 6.010076109000 & 5.632948414000 & $53 \mathrm{H}$ & 14.791681060000 & 6.018930968000 & 5.611468572000 \\
\hline $54 \mathrm{C}$ & 11.284397900000 & 4.049962053000 & 5.840519942000 & $54 \mathrm{C}$ & 11.317274660000 & 4.000703302000 & 5.888419359000 \\
\hline $55 \mathrm{H}$ & 10.369249940000 & 4.000760918000 & 6.447714374000 & $55 \mathrm{H}$ & 10.408787390000 & 3.960253336000 & 6.507141677000 \\
\hline $56 \mathrm{H}$ & 11.799891820000 & 3.077228923000 & 5.923667585000 & $56 \mathrm{H}$ & 11.838141790000 & 3.032038231000 & 5.985947564000 \\
\hline $57 \mathrm{H}$ & 10.984852720000 & 4.160700527000 & 4.787449155000 & $57 \mathrm{H}$ & 11.004483780000 & 4.096901364000 & 4.838514827000 \\
\hline $58 \mathrm{C}$ & 12.975412080000 & 4.883225869000 & 8.183296729000 & $58 \mathrm{C}$ & 13.045643450000 & 4.879294866000 & 8.191405054000 \\
\hline $59 \mathrm{H}$ & 13.729651270000 & 5.544251612000 & 8.635268194000 & $59 \mathrm{H}$ & 13.794073110000 & 5.560721524000 & 8.623335959000 \\
\hline $60 \mathrm{H}$ & 13.400656620000 & 3.865824202000 & 8.149162926000 & $60 \mathrm{H}$ & 13.492926230000 & 3.871414693000 & 8.155376179000 \\
\hline $61 \mathrm{H}$ & 12.101713060000 & 4.858955106000 & 8.851630443000 & $61 \mathrm{H}$ & 12.186543180000 & 4.841038155000 & 8.878317728000 \\
\hline${ }_{1 \mathrm{U}}[\mathrm{U}(\mathrm{I}$ & $\begin{array}{c}\left.\text { IV) } \mathbf{N}^{*}{ }_{2} \mathbf{C N}_{\mathbf{3}}\right]^{1-975453302000} \\
{ }^{1-}\end{array}$ & 7.306725179000 & 4.879117340000 & ${ }_{10}^{[U}$ & $\begin{array}{l}\left.(\mathrm{IV}) \mathrm{N}^{*}{ }_{2} \mathrm{NC}_{3}\right]^{1-} \\
9.937883397000\end{array}$ & 7.282841429000 & 4.899762000000 \\
\hline $2 \mathrm{Si}$ & 10.923643780000 & 9.647472487000 & 2.474381091000 & $2 \mathrm{Si}$ & 10.878127960000 & 9.641462564000 & 2.490337497000 \\
\hline $3 \mathrm{Si}$ & 7.985110042000 & 9.710432446000 & 3.383663218000 & $3 \mathrm{Si}$ & 7.944664927000 & 9.685712383000 & 3.391897049000 \\
\hline $4 \mathrm{Si}$ & 12.292233630000 & 8.332291992000 & 7.282584159000 & $4 \mathrm{Si}$ & 12.339154120000 & 8.333438082000 & 7.247289579000 \\
\hline $5 \mathrm{Si}$ & 12.418904110000 & 5.389254442000 & 6.390207217000 & $5 \mathrm{Si}$ & 12.442554930000 & 5.399485456000 & 6.381924242000 \\
\hline $6 \mathrm{~N}$ & 11.550533080000 & 5.447871223000 & 2.080727094000 & $6 \mathrm{C}$ & 11.287098220000 & 5.501948617000 & 2.116293070000 \\
\hline $7 \mathrm{~N}$ & 7.411293603000 & 4.721465691000 & 4.885366118000 & $7 C$ & 7.462449476000 & 4.774374789000 & 5.092484934000 \\
\hline $8 \mathrm{~N}$ & 8.116595862000 & 8.806445081000 & 7.715078538000 & $8 \mathrm{C}$ & 8.241223468000 & 8.819900038000 & 7.639355200000 \\
\hline $9 \mathrm{~N}$ & 9.620112956000 & 9.032986788000 & 3.498677255000 & $9 \mathrm{~N}$ & 9.579527837000 & 9.017523200000 & 3.510735692000 \\
\hline $10 \mathrm{~N}$ & 11.711537380000 & 7.009770810000 & 6.261677412000 & $10 \mathrm{~N}$ & 11.728930750000 & 7.012786464000 & 6.244544649000 \\
\hline $11 \mathrm{C}$ & 11.031294670000 & 6.017238305000 & 2.967494680000 & $11 \mathrm{~N}$ & 10.925234080000 & 6.073770713000 & 3.089726674000 \\
\hline $12 \mathrm{C}$ & 8.238858808000 & 5.555772963000 & 4.886235477000 & $12 \mathrm{~N}$ & 8.287114587000 & 5.622317374000 & 5.003804731000 \\
\hline $13 \mathrm{C}$ & 8.662837513000 & 8.330911455000 & 6.790082339000 & $13 \mathrm{~N}$ & 8.786037057000 & 8.381209262000 & 6.682070248000 \\
\hline $14 \mathrm{C}$ & 11.005816400000 & 11.543292240000 & 2.531108044000 & $14 \mathrm{C}$ & 10.963278510000 & 11.536446630000 & 2.572413950000 \\
\hline $15 \mathrm{H}$ & 11.157185280000 & 11.904638360000 & 3.558981429000 & $15 \mathrm{H}$ & 11.111560190000 & 11.882114820000 & 3.605849702000 \\
\hline $16 \mathrm{H}$ & 10.096237920000 & 12.019908660000 & 2.138418878000 & $16 \mathrm{H}$ & 10.054640260000 & 12.018659440000 & 2.184156542000 \\
\hline $17 \mathrm{H}$ & 11.853113050000 & 11.896669430000 & 1.922163020000 & $17 \mathrm{H}$ & 11.811822550000 & 11.898277750000 & 1.970119082000 \\
\hline $18 \mathrm{C}$ & 10.752695000000 & 9.091025722000 & 0.679310513800 & $18 \mathrm{C}$ & 10.703208260000 & 9.120698887000 & 0.682675958300 \\
\hline $19 \mathrm{H}$ & 11.615878360000 & 9.444656038000 & 0.093332832670 & $19 \mathrm{H}$ & 11.581897880000 & 9.459636321000 & 0.111134426300 \\
\hline $20 \mathrm{H}$ & 9.841626480000 & 9.473442893000 & 0.200476186800 & $20 \mathrm{H}$ & 9.808683655000 & 9.538039345000 & 0.202299230600 \\
\hline $21 \mathrm{H}$ & 10.739136240000 & 7.992243259000 & 0.627732364100 & $21 \mathrm{H}$ & 10.657926620000 & 8.024310478000 & 0.608095183500 \\
\hline $22 \mathrm{c}$ & 12.615392050000 & 9.026227950000 & 3.059063069000 & $22 \mathrm{C}$ & 12.571881840000 & 9.002290455000 & 3.047004608000 \\
\hline $23 \mathrm{H}$ & 12.863913100000 & 9.293733913000 & 4.094531848000 & $23 \mathrm{H}$ & 12.802870190000 & 9.191260534000 & 4.102971052000 \\
\hline $24 \mathrm{H}$ & 13.374722650000 & 9.501277989000 & 2.416072720000 & $24 \mathrm{H}$ & 13.334695520000 & 9.531041581000 & 2.452010902000 \\
\hline $25 \mathrm{H}$ & 12.728853860000 & 7.939904347000 & 2.939038889000 & $25 \mathrm{H}$ & 12.691403060000 & 7.928400081000 & 2.853825874000 \\
\hline $26 \mathrm{C}$ & 7.508999560000 & 10.186719310000 & 1.608260992000 & $26 \mathrm{C}$ & 7.463935286000 & 10.146376060000 & 1.613166638000 \\
\hline $27 \mathrm{H}$ & 8.142098625000 & 10.975323190000 & 1.178211324000 & $27 \mathrm{H}$ & 8.086878217000 & 10.942476080000 & 1.182267038000 \\
\hline $28 \mathrm{H}$ & 6.473443694000 & 10.563893150000 & 1.615837058000 & $28 \mathrm{H}$ & 6.423157302000 & 10.508753510000 & 1.615477218000 \\
\hline $29 \mathrm{H}$ & 7.539043115000 & 9.316725114000 & 0.936799547000 & $29 \mathrm{H}$ & 7.510398701000 & 9.274579585000 & 0.945248256500 \\
\hline $30 \mathrm{C}$ & 7.819335826000 & 11.248447080000 & 4.467713796000 & $30 \mathrm{c}$ & 7.757553777000 & 11.233882960000 & 4.459011072000 \\
\hline $31 \mathrm{H}$ & 7.959500377000 & 10.985841940000 & 5.526347611000 & $31 \mathrm{H}$ & 7.925892826000 & 10.992118890000 & 5.518091154000 \\
\hline $32 \mathrm{H}$ & 6.815448401000 & 11.689061020000 & 4.360632846000 & $32 \mathrm{H}$ & 6.740060077000 & 11.645152860000 & 4.364589470000 \\
\hline $33 \mathrm{H}$ & 8.556848342000 & 12.019547740000 & 4.203406906000 & $33 \mathrm{H}$ & 8.467803167000 & 12.020854340000 & 4.168581698000 \\
\hline $34 \mathrm{C}$ & 6.707185876000 & 8.437869784000 & 3.933482535000 & $34 \mathrm{C}$ & 6.671868273000 & 8.408750899000 & 3.947198631000 \\
\hline $35 \mathrm{H}$ & 6.693968939000 & 7.540651036000 & 3.299002979000 & $35 \mathrm{H}$ & 6.684220081000 & 7.499138806000 & 3.330248463000 \\
\hline $36 \mathrm{H}$ & 5.714711296000 & 8.912721352000 & 3.857954399000 & $36 \mathrm{H}$ & 5.673811136000 & 8.865439515000 & 3.841938728000 \\
\hline $37 \mathrm{H}$ & 6.816547201000 & 8.113499761000 & 4.978170557000 & $37 \mathrm{H}$ & 6.771538873000 & 8.106867545000 & 4.998538778000 \\
\hline $38 \mathrm{C}$ & 14.186864430000 & 8.451211589000 & 7.244113047000 & $38 \mathrm{C}$ & 14.237713230000 & 8.407174444000 & 7.230349365000 \\
\hline $39 \mathrm{H}$ & 14.677881390000 & 7.555484554000 & 7.650547040000 & $39 \mathrm{H}$ & 14.708967810000 & 7.514829100000 & 7.665795595000 \\
\hline $40 \mathrm{H}$ & 14.516351500000 & 9.311554339000 & 7.848489580000 & $40 \mathrm{H}$ & 14.573970580000 & 9.277420332000 & 7.816890421000 \\
\hline $41 \mathrm{H}$ & 14.556310560000 & 8.600668234000 & 6.218820972000 & $41 \mathrm{H}$ & 14.621890470000 & 8.525784881000 & 6.206530147000 \\
\hline $42 C$ & 11.722975470000 & 8.160763470000 & 9.072789230000 & $42 \mathrm{C}$ & 11.759398590000 & 8.196014329000 & 9.039379236000 \\
\hline $43 \mathrm{H}$ & 10.624234610000 & 8.136093085000 & 9.116440178000 & $43 \mathrm{H}$ & 10.660918380000 & 8.222601540000 & 9.086039148000 \\
\hline $44 \mathrm{H}$ & 12.064599150000 & 9.028347240000 & 9.659479480000 & $44 \mathrm{H}$ & 12.142682630000 & 9.045952063000 & 9.626141331000 \\
\hline $45 \mathrm{H}$ & 12.111737470000 & 7.254550578000 & 9.555760865000 & $45 \mathrm{H}$ & 12.103165750000 & 7.271630159000 & 9.522256312000 \\
\hline $46 \mathrm{C}$ & 11.649540540000 & 10.008485850000 & 6.677870411000 & $46 \mathrm{C}$ & 11.771195080000 & 10.028896930000 & 6.616441178000 \\
\hline $47 \mathrm{H}$ & 11.992629250000 & 10.284085380000 & 5.671853123000 & $47 \mathrm{H}$ & 12.307626380000 & 10.353648600000 & 5.715023900000 \\
\hline $48 \mathrm{H}$ & 12.039311830000 & 10.772991350000 & 7.370330071000 & $48 \mathrm{H}$ & 11.993816760000 & 10.763002820000 & 7.408191814000 \\
\hline $49 \mathrm{H}$ & 10.553487040000 & 10.081909530000 & 6.711193285000 & $49 \mathrm{H}$ & 10.690936170000 & 10.092224640000 & 6.428519194000 \\
\hline $50 \mathrm{C}$ & 13.965641900000 & 5.244664225000 & 5.315645968000 & $50 \mathrm{C}$ & 13.979888180000 & 5.245223140000 & 5.293421821000 \\
\hline
\end{tabular}




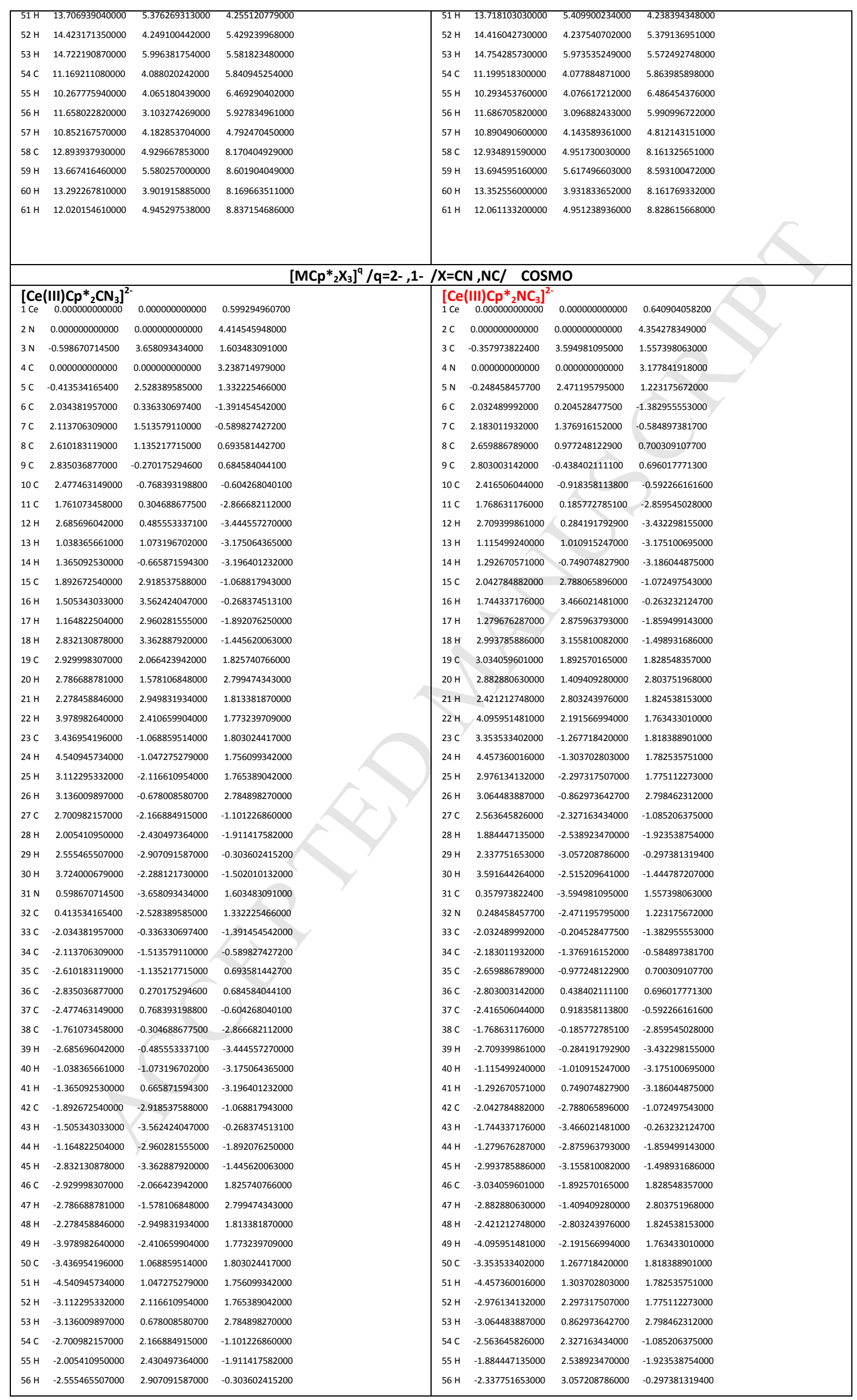




\begin{tabular}{|c|c|c|c|c|c|c|c|}
\hline $57 \mathrm{H}$ & -3.724000679000 & 2.288121730000 & -1.502010132000 & $57 \mathrm{H}$ & -3.591644264000 & 2.515209641000 & -1.444787207000 \\
\hline$[\mathrm{U}(\mathrm{I}$ & III) $\left.\mathrm{Cp}_{2}{ }_{2} \mathrm{CN}_{3}\right]^{2-}$ & & & & (III)Cp $\left.{ }_{2}{ }_{2} \mathrm{NC}_{3}\right]^{2-}$ & & \\
\hline & & 0.000000000000 & 0.579911769800 & & & 0.000000000000 & 0.632549000000 \\
\hline $2 \mathrm{~N}$ & 0.000000000000 & 0.000000000000 & 4.360438248000 & $2 c$ & 0.000000000000 & 0.000000000000 & 4.305505000000 \\
\hline $3 \mathrm{~N}$ & -0.409575461800 & 3.580387961000 & 1.628155337000 & $3 c$ & -0.323763000000 & 3.547740000000 & 1.502163000000 \\
\hline $4 \mathrm{C}$ & 0.000000000000 & 0.000000000000 & 3.184891866000 & $4 \mathrm{~N}$ & 0.000000000000 & 0.000000000000 & 3.127746000000 \\
\hline $5 \mathrm{C}$ & -0.274055746700 & 2.447833806000 & 1.332904663000 & $5 \mathrm{~N}$ & -0.242201000000 & 2.410313000000 & 1.196694000000 \\
\hline $6 \mathrm{C}$ & 2.351421602000 & -0.907100117800 & -0.625649931900 & $6 c$ & 2.372926000000 & -0.938348000000 & -0.561304000000 \\
\hline $7 C$ & 1.969696628000 & 0.241507952700 & -1.386657103000 & $7 c$ & 1.973458000000 & 0.171150000000 & -1.369432000000 \\
\hline $8 \mathrm{C}$ & 2.124901975000 & 1.392868297000 & -0.550878552000 & $8 \mathrm{C}$ & 2.133244000000 & 1.360683000000 & -0.592400000000 \\
\hline $9 \mathrm{C}$ & 2.606340728000 & 0.952008249200 & 0.721227810300 & $9 \mathrm{C}$ & 2.623614000000 & 0.983607000000 & 0.694370000000 \\
\hline $10 \mathrm{C}$ & 2.752611768000 & -0.465785304000 & 0.673137043100 & $10 \mathrm{C}$ & 2.770333000000 & -0.433988000000 & 0.713505000000 \\
\hline $11 \mathrm{c}$ & 2.477261201000 & -2.304750947000 & -1.158473425000 & $11 \mathrm{c}$ & 2.529574000000 & -2.351079000000 & -1.039098000000 \\
\hline $12 \mathrm{H}$ & 1.741260528000 & -2.505667487000 & -1.952212177000 & $12 \mathrm{H}$ & 1.772842000000 & -2.613123000000 & -1.793693000000 \\
\hline $13 \mathrm{H}$ & 2.310079990000 & -3.051661349000 & -0.370542882600 & $13 \mathrm{H}$ & 2.415952000000 & -3.068147000000 & -0.216162000000 \\
\hline $14 \mathrm{H}$ & 3.479239138000 & -2.477587096000 & -1.593958236000 & $14 \mathrm{H}$ & 3.522115000000 & -2.506425000000 & -1.502334000000 \\
\hline $15 \mathrm{C}$ & 1.741151936000 & 0.270133517100 & -2.869763100000 & $15 \mathrm{C}$ & 1.743990000000 & 0.125427000000 & -2.851718000000 \\
\hline $16 \mathrm{H}$ & 1.093969402000 & 1.105241560000 & -3.173531971000 & $16 \mathrm{H}$ & 1.092489000000 & 0.940146000000 & -3.196469000000 \\
\hline $17 \mathrm{H}$ & 1.273762183000 & -0.654403331100 & -3.236974386000 & $17 \mathrm{H}$ & 1.280802000000 & -0.818917000000 & -3.169874000000 \\
\hline $18 \mathrm{H}$ & 2.696599330000 & 0.388160032000 & -3.416607750000 & $18 \mathrm{H}$ & 2.698856000000 & 0.218803000000 & -3.404202000000 \\
\hline $19 \mathrm{C}$ & 1.998142002000 & 2.818348615000 & -1.003010422000 & $19 \mathrm{C}$ & 1.993188000000 & 2.761382000000 & -1.108843000000 \\
\hline $20 \mathrm{H}$ & 2.942504506000 & 3.181828089000 & -1.450723774000 & $20 \mathrm{H}$ & 2.939552000000 & 3.117279000000 & -1.557743000000 \\
\hline $21 \mathrm{H}$ & 1.730194961000 & 3.481764677000 & -0.170211319100 & $21 \mathrm{H}$ & 1.706601000000 & 3.457214000000 & -0.309845000000 \\
\hline $22 \mathrm{H}$ & 1.213148522000 & 2.935855657000 & -1.765799995000 & $22 \mathrm{H}$ & 1.217679000000 & 2.832146000000 & -1.885863000000 \\
\hline $23 \mathrm{C}$ & 3.007651389000 & 1.832611213000 & 1.868640072000 & $23 \mathrm{C}$ & 3.005912000000 & 1.917388000000 & 1.805035000000 \\
\hline $24 \mathrm{H}$ & 2.839798085000 & 1.332923783000 & 2.833486842000 & $24 \mathrm{H}$ & 2.843414000000 & 1.456053000000 & 2.789662000000 \\
\hline $25 \mathrm{H}$ & 2.419829728000 & 2.760029252000 & 1.883910594000 & $25 \mathrm{H}$ & 2.403580000000 & 2.834901000000 & 1.779310000000 \\
\hline $26 \mathrm{H}$ & 4.079427802000 & 2.101333586000 & 1.808275544000 & $26 \mathrm{H}$ & 4.072805000000 & 2.200603000000 & 1.738736000000 \\
\hline $27 \mathrm{C}$ & 3.342680512000 & -1.315818644000 & 1.759540943000 & $27 \mathrm{C}$ & 3.327132000000 & -1.241997000000 & 1.848832000000 \\
\hline $28 \mathrm{H}$ & 4.447895703000 & -1.309722491000 & 1.710572206000 & $28 \mathrm{H}$ & 4.428160000000 & -1.320174000000 & 1.781444000000 \\
\hline $29 \mathrm{H}$ & 2.997258827000 & -2.355286995000 & 1.686606445000 & $29 \mathrm{H}$ & 2.910193000000 & -2.257821000000 & 1.856071000000 \\
\hline $30 \mathrm{H}$ & 3.049470505000 & -0.953406119200 & 2.755919585000 & $30 \mathrm{H}$ & 3.083371000000 & -0.788742000000 & 2.820261000000 \\
\hline $31 \mathrm{~N}$ & 0.409575461800 & -3.580387961000 & 1.628155337000 & $31 \mathrm{C}$ & 0.323763000000 & -3.547740000000 & 1.502163000000 \\
\hline $32 \mathrm{C}$ & 0.274055746700 & -2.447833806000 & 1.332904663000 & $32 \mathrm{~N}$ & 0.242201000000 & -2.410313000000 & 1.196694000000 \\
\hline $33 \mathrm{C}$ & -2.351421602000 & 0.907100117800 & -0.625649931900 & $33 \mathrm{C}$ & -2.372926000000 & 0.938348000000 & -0.561304000000 \\
\hline $34 \mathrm{C}$ & -1.969696628000 & -0.241507952700 & -1.386657103000 & $34 \mathrm{C}$ & -1.973458000000 & -0.171150000000 & -1.369432000000 \\
\hline $35 \mathrm{C}$ & -2.124901975000 & -1.392868297000 & -0.550878552000 & $35 \mathrm{C}$ & -2.133244000000 & -1.360683000000 & -0.592400000000 \\
\hline $36 \mathrm{C}$ & -2.606340728000 & -0.952008249200 & 0.721227810300 & $36 \mathrm{C}$ & -2.623614000000 & -0.983607000000 & 0.694370000000 \\
\hline $37 \mathrm{C}$ & -2.752611768000 & 0.465785304000 & 0.673137043100 & $37 \mathrm{C}$ & -2.770333000000 & 0.433988000000 & 0.713505000000 \\
\hline $38 \mathrm{C}$ & -2.477261201000 & 2.304750947000 & -1.158473425000 & $38 \mathrm{C}$ & -2.529574000000 & 2.351079000000 & -1.039098000000 \\
\hline $39 \mathrm{H}$ & -1.741260528000 & 2.505667487000 & -1.952212177000 & $39 \mathrm{H}$ & -1.772842000000 & 2.613123000000 & -1.793693000000 \\
\hline $40 \mathrm{H}$ & -2.310079990000 & 3.051661349000 & -0.370542882600 & $40 \mathrm{H}$ & -2.415952000000 & 3.068147000000 & -0.216162000000 \\
\hline $41 \mathrm{H}$ & -3.479239138000 & 2.477587096000 & -1.593958236000 & $41 \mathrm{H}$ & -3.522115000000 & 2.506425000000 & -1.502334000000 \\
\hline $42 \mathrm{C}$ & -1.741151936000 & -0.270133517100 & -2.869763100000 & $42 \mathrm{C}$ & -1.743990000000 & -0.125427000000 & -2.851718000000 \\
\hline $43 \mathrm{H}$ & -1.093969402000 & -1.105241560000 & -3.173531971000 & $43 \mathrm{H}$ & -1.092489000000 & -0.940146000000 & -3.196469000000 \\
\hline $44 \mathrm{H}$ & -1.273762183000 & 0.654403331100 & -3.236974386000 & $44 \mathrm{H}$ & -1.280802000000 & 0.818917000000 & -3.169874000000 \\
\hline $45 \mathrm{H}$ & -2.696599330000 & -0.388160032000 & -3.416607750000 & $45 \mathrm{H}$ & -2.698856000000 & -0.218803000000 & -3.404202000000 \\
\hline $46 C$ & -1.998142002000 & -2.818348615000 & -1.003010422000 & $46 C$ & -1.993188000000 & -2.761382000000 & -1.108843000000 \\
\hline $47 \mathrm{H}$ & -2.942504506000 & -3.181828089000 & -1.450723774000 & $47 \mathrm{H}$ & -2.939552000000 & -3.117279000000 & -1.557743000000 \\
\hline $48 \mathrm{H}$ & -1.730194961000 & -3.481764677000 & -0.170211319100 & $48 \mathrm{H}$ & -1.706601000000 & -3.457214000000 & -0.309845000000 \\
\hline $49 \mathrm{H}$ & -1.213148522000 & -2.935855657000 & -1.765799995000 & $49 \mathrm{H}$ & -1.217679000000 & -2.832146000000 & -1.885863000000 \\
\hline $50 \mathrm{C}$ & -3.007651389000 & -1.832611213000 & 1.868640072000 & $50 \mathrm{C}$ & -3.005912000000 & -1.917388000000 & 1.805035000000 \\
\hline $51 \mathrm{H}$ & -2.839798085000 & -1.332923783000 & 2.833486842000 & $51 \mathrm{H}$ & -2.843414000000 & -1.456053000000 & 2.789662000000 \\
\hline $52 \mathrm{H}$ & -2.419829728000 & -2.760029252000 & 1.883910594000 & $52 \mathrm{H}$ & -2.403580000000 & -2.834901000000 & 1.779310000000 \\
\hline $53 \mathrm{H}$ & -4.079427802000 & -2.101333586000 & 1.808275544000 & $53 \mathrm{H}$ & -4.072805000000 & -2.200603000000 & 1.738736000000 \\
\hline $54 \mathrm{C}$ & -3.342680512000 & 1.315818644000 & 1.759540943000 & $54 \mathrm{C}$ & -3.327132000000 & 1.241997000000 & 1.848832000000 \\
\hline $55 \mathrm{H}$ & -4.447895703000 & 1.309722491000 & 1.710572206000 & $55 \mathrm{H}$ & -4.428160000000 & 1.320174000000 & 1.781444000000 \\
\hline $56 \mathrm{H}$ & -2.997258827000 & 2.355286995000 & 1.686606445000 & $56 \mathrm{H}$ & -2.910193000000 & 2.257821000000 & 1.856071000000 \\
\hline $57 \mathrm{H}$ & -3.049470505000 & 0.953406119200 & 2.755919585000 & $57 \mathrm{H}$ & -3.083371000000 & 0.788742000000 & 2.820261000000 \\
\hline$\left[\begin{array}{l}\text { [U(I) } \\
\text { IU }\end{array}\right.$ & $\begin{array}{c}\left.\text { IV) } \mathrm{Cp}^{*}{ }_{2} \mathrm{CN}_{3}\right]^{1-} \\
0.000000000000\end{array}$ & 0.000000000000 & 0.423341000000 & {$\left[\begin{array}{ll}I_{U}(I) \\
\end{array}\right.$} & $\begin{array}{c}\left.\text { (IV)Cp}{ }_{2}{ }_{2} \mathrm{NC}_{3}\right]^{1-} \\
0.00000000000\end{array}$ & 0.000000000000 & 0.569583000000 \\
\hline $2 \mathrm{~N}$ & -0.039158000000 & -3.518341000000 & 1.560553000000 & $2 c$ & -0.001737000000 & -3.480360000000 & 1.500258000000 \\
\hline $3 \mathrm{~N}$ & 0.000000000000 & 0.000000000000 & 4.116776000000 & $3 c$ & 0.000000000000 & 0.000000000000 & 4.178328000000 \\
\hline $4 \mathrm{~N}$ & 0.039158000000 & 3.518341000000 & 1.560553000000 & $4 C$ & 0.001737000000 & 3.480360000000 & 1.500258000000 \\
\hline $5 \mathrm{C}$ & -0.028795000000 & -2.390420000000 & 1.227273000000 & $5 \mathrm{~N}$ & -0.000431000000 & -2.354196000000 & 1.146471000000 \\
\hline $6 C$ & 0.000000000000 & 0.000000000000 & 2.941015000000 & $6 \mathrm{~N}$ & 0.000000000000 & 0.000000000000 & 2.998262000000 \\
\hline $7 \mathrm{C}$ & 0.028795000000 & 2.390420000000 & 1.227273000000 & $7 N$ & 0.000431000000 & 2.354196000000 & 1.146471000000 \\
\hline $8 \mathrm{C}$ & -2.696014000000 & 0.664290000000 & 0.814012000000 & $8 \mathrm{C}$ & -2.676426000000 & 0.715516000000 & 0.639185000000 \\
\hline $9 \mathrm{C}$ & -2.660852000000 & -0.757250000000 & 0.664620000000 & $9 \mathrm{C}$ & -2.676843000000 & -0.713623000000 & 0.639919000000 \\
\hline
\end{tabular}




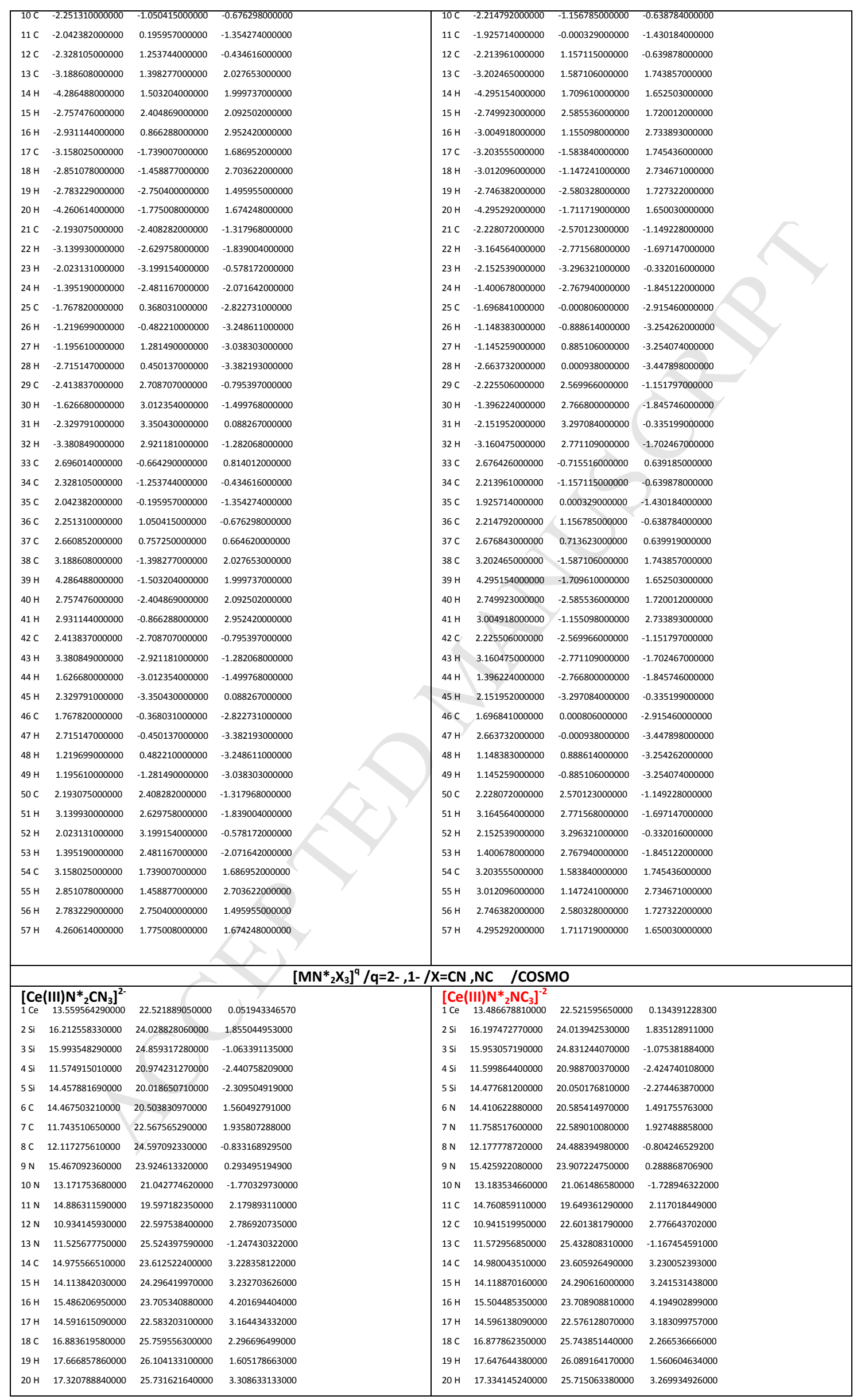




\begin{tabular}{|c|c|c|c|c|c|c|c|}
\hline $21 \mathrm{H}$ & 16.077179190000 & 26.507874670000 & 2.297269091000 & $21 \mathrm{H}$ & 16.071858950000 & 26.492646370000 & 2.282533264000 \\
\hline $22 \mathrm{C}$ & 17.671078460000 & 22.824012900000 & 2.031116451000 & $22 \mathrm{C}$ & 17.657073260000 & 22.808744270000 & 1.999243904000 \\
\hline $23 \mathrm{H}$ & 17.312341370000 & 21.788308460000 & 1.932217363000 & $23 \mathrm{H}$ & 17.299019660000 & 21.773544120000 & 1.896337268000 \\
\hline $24 \mathrm{H}$ & 18.155548800000 & 22.927756450000 & 3.015875866000 & $24 \mathrm{H}$ & 18.147292620000 & 22.907829410000 & 2.981550899000 \\
\hline $25 \mathrm{H}$ & 18.427896960000 & 23.000117300000 & 1.251774542000 & $25 \mathrm{H}$ & 18.409401430000 & 22.988545120000 & 1.216537838000 \\
\hline $26 \mathrm{C}$ & 15.572667060000 & 26.706818890000 & -0.915816875000 & $26 \mathrm{C}$ & 15.533911880000 & 26.681135980000 & -0.938097435300 \\
\hline $27 \mathrm{H}$ & 14.485489490000 & 26.820483050000 & -0.785692056200 & $27 \mathrm{H}$ & 14.447093360000 & 26.797771040000 & -0.809077284800 \\
\hline $28 \mathrm{H}$ & 15.868675140000 & 27.245661250000 & -1.830824517000 & $28 \mathrm{H}$ & 15.830953350000 & 27.214708590000 & -1.855882268000 \\
\hline $29 \mathrm{H}$ & 16.076483450000 & 27.179913830000 & -0.060769553950 & $29 \mathrm{H}$ & 16.037704080000 & 27.158279770000 & -0.085289245330 \\
\hline $30 \mathrm{C}$ & 17.869840360000 & 24.732960450000 & -1.380425171000 & $30 \mathrm{C}$ & 17.833062550000 & 24.710255620000 & -1.381459948000 \\
\hline $31 \mathrm{H}$ & 18.456221660000 & 25.118715200000 & -0.532368747100 & $31 \mathrm{H}$ & 18.417256760000 & 25.099248820000 & -0.533712254600 \\
\hline $32 \mathrm{H}$ & 18.151124510000 & 25.313460110000 & -2.274283147000 & $32 \mathrm{H}$ & 18.114386160000 & 25.289259230000 & -2.276445934000 \\
\hline $33 \mathrm{H}$ & 18.169205120000 & 23.686533960000 & -1.543904556000 & $33 \mathrm{H}$ & 18.135880300000 & 23.664322600000 & -1.542782726000 \\
\hline $34 \mathrm{C}$ & 15.142835870000 & 24.283845840000 & -2.659145057000 & $34 \mathrm{C}$ & 15.125642180000 & 24.258019320000 & -2.682219083000 \\
\hline $35 \mathrm{H}$ & 15.317929560000 & 23.226301420000 & -2.901490212000 & $35 \mathrm{H}$ & 15.306247460000 & 23.200769810000 & -2.919369116000 \\
\hline $36 \mathrm{H}$ & 15.536352060000 & 24.877135590000 & -3.500806235000 & $36 \mathrm{H}$ & 15.530786880000 & 24.854886210000 & -3.516034041000 \\
\hline $37 \mathrm{H}$ & 14.055877110000 & 24.454205500000 & -2.625718430000 & $37 \mathrm{H}$ & 14.038663610000 & 24.421580750000 & -2.657969343000 \\
\hline $38 \mathrm{C}$ & 11.017727260000 & 19.228278330000 & -2.970969516000 & $38 \mathrm{C}$ & 11.057099360000 & 19.246045680000 & -2.981707392000 \\
\hline $39 \mathrm{H}$ & 11.654643530000 & 18.796488330000 & -3.757276126000 & $39 \mathrm{H}$ & 11.707390260000 & 18.823606470000 & -3.761998273000 \\
\hline $40 \mathrm{H}$ & 9.989032774000 & 19.278186400000 & -3.364776192000 & $40 \mathrm{H}$ & 10.034346230000 & 19.296478940000 & -3.390665747000 \\
\hline $41 \mathrm{H}$ & 11.019082870000 & 18.537251510000 & -2.114756249000 & $41 \mathrm{H}$ & 11.047712350000 & 18.546374560000 & -2.132600205000 \\
\hline $42 C$ & 11.392655190000 & 22.085622860000 & -3.971028968000 & $42 \mathrm{C}$ & 11.425257200000 & 22.116374430000 & -3.944228571000 \\
\hline $43 \mathrm{H}$ & 11.573242750000 & 23.135057910000 & -3.693607049000 & $43 \mathrm{H}$ & 11.606046610000 & 23.162302810000 & -3.654703592000 \\
\hline $44 \mathrm{H}$ & 10.378335170000 & 22.012349490000 & -4.396336023000 & $44 \mathrm{H}$ & 10.413628780000 & 22.048788390000 & -4.376754421000 \\
\hline $45 \mathrm{H}$ & 12.116613740000 & 21.808721530000 & -4.752202710000 & $45 \mathrm{H}$ & 12.154149830000 & 21.847221650000 & -4.723478828000 \\
\hline $46 \mathrm{C}$ & 10.280699810000 & 21.547521450000 & -1.182442323000 & $46 \mathrm{C}$ & 10.281695390000 & 21.532713320000 & -1.175889360000 \\
\hline $47 \mathrm{H}$ & 10.274719870000 & 20.922828390000 & -0.277164063600 & $47 \mathrm{H}$ & 10.280455500000 & 20.904114750000 & -0.272911288900 \\
\hline $48 \mathrm{H}$ & 9.283628253000 & 21.478723790000 & -1.649453422000 & $48 \mathrm{H}$ & 9.290790255000 & 21.439361820000 & -1.651458466000 \\
\hline $49 \mathrm{H}$ & 10.416516220000 & 22.594047510000 & -0.870219052900 & $49 \mathrm{H}$ & 10.389498030000 & 22.581025210000 & -0.860524657600 \\
\hline $50 \mathrm{C}$ & 14.674621600000 & 20.021820220000 & -4.204640817000 & $50 \mathrm{C}$ & 14.686025210000 & 20.060362350000 & -4.171961134000 \\
\hline $51 \mathrm{H}$ & 13.780449110000 & 19.641545700000 & -4.721986380000 & $51 \mathrm{H}$ & 13.791794570000 & 19.682490280000 & -4.690484088000 \\
\hline $52 \mathrm{H}$ & 15.527014990000 & 19.387089610000 & -4.497406069000 & $52 \mathrm{H}$ & 15.538163940000 & 19.426446660000 & -4.467807897000 \\
\hline $53 \mathrm{H}$ & 14.864986350000 & 21.041285280000 & -4.573641829000 & $53 \mathrm{H}$ & 14.877059580000 & 21.080913570000 & -4.537775337000 \\
\hline $54 \mathrm{C}$ & 14.256121630000 & 18.207878350000 & -1.770772811000 & $54 \mathrm{C}$ & 14.283886600000 & 18.232627120000 & -1.751327843000 \\
\hline $55 \mathrm{H}$ & 14.188895550000 & 18.161971490000 & -0.673045614800 & $55 \mathrm{H}$ & 14.206656370000 & 18.176105840000 & -0.654928271100 \\
\hline $56 \mathrm{H}$ & 15.126283810000 & 17.610294890000 & -2.088268973000 & $56 \mathrm{H}$ & 15.161141350000 & 17.643826620000 & -2.065926477000 \\
\hline $57 \mathrm{H}$ & 13.351412640000 & 17.748257110000 & -2.193988472000 & $57 \mathrm{H}$ & 13.386392560000 & 17.770297520000 & -2.186661175000 \\
\hline $58 \mathrm{C}$ & 16.123053720000 & 20.569342430000 & -1.586013495000 & $58 \mathrm{C}$ & 16.150234240000 & 20.594053440000 & -1.567184725000 \\
\hline $59 \mathrm{H}$ & 16.400776630000 & 21.600596440000 & -1.845463558000 & $59 \mathrm{H}$ & 16.422218860000 & 21.626118530000 & -1.826940088000 \\
\hline $60 \mathrm{H}$ & 16.913330620000 & 19.912676460000 & -1.985261134000 & $60 \mathrm{H}$ & 16.934155710000 & 19.936277180000 & -1.977341531000 \\
\hline $61 \mathrm{H}$ & 16.146472460000 & 20.471248000000 & -0.489998860000 & $61 \mathrm{H}$ & 16.179620460000 & 20.498022320000 & -0.472328148600 \\
\hline$\left[{ }_{1 U}{ }^{(I I}\right.$ & $\begin{array}{l}\left.\text { III) } \mathbf{N}_{2}{ }_{2} \mathrm{CN}_{3}\right]^{\mathbf{2}^{-}} \\
9.8651081250000\end{array}$ & 7.196436014000 & 4.887045754000 & {$[\mathrm{U}(\mathrm{U})$} & $\begin{array}{l}\left.\text { III) } \mathrm{N}_{2}{ }_{2} \mathrm{NC}_{3}\right]^{2^{2-}} \\
9.848699368000\end{array}$ & 7.187468814000 & 4.887482808000 \\
\hline $2 \mathrm{Si}$ & 10.956692310000 & 9.614008972000 & 2.493877250000 & $2 \mathrm{Si}$ & 10.935166490000 & 9.627198803000 & 2.490260305000 \\
\hline $3 \mathrm{Si}$ & 8.039157364000 & 9.741004467000 & 3.349834560000 & $3 \mathrm{Si}$ & 8.031232992000 & 9.754262572000 & 3.358834680000 \\
\hline $4 \mathrm{Si}$ & 12.234809420000 & 8.361749759000 & 7.285351697000 & $4 \mathrm{Si}$ & 12.247827970000 & 8.328156888000 & 7.287802802000 \\
\hline $5 \mathrm{Si}$ & 12.482969790000 & 5.456371461000 & 6.411009943000 & $5 \mathrm{Si}$ & 12.472899130000 & 5.433050715000 & 6.402059490000 \\
\hline $6 \mathrm{~N}$ & 11.270075660000 & 5.222982565000 & 1.972658145000 & $6 \mathrm{C}$ & 11.200506960000 & 5.325775487000 & 2.039673269000 \\
\hline $7 \mathrm{~N}$ & 7.291939496000 & 4.495111074000 & 4.877864688000 & $7 c$ & 7.316433030000 & 4.595540576000 & 4.833028653000 \\
\hline $8 \mathrm{~N}$ & 7.795759376000 & 8.515907391000 & 7.771455120000 & $8 \mathrm{C}$ & 7.904918961000 & 8.429582887000 & 7.734344115000 \\
\hline $9 \mathrm{~N}$ & 9.632714523000 & 9.053138267000 & 3.467248885000 & $9 \mathrm{~N}$ & 9.621600611000 & 9.063677926000 & 3.476051662000 \\
\hline $10 \mathrm{~N}$ & 11.728840000000 & 7.020337594000 & 6.304944243000 & $10 \mathrm{~N}$ & 11.728919910000 & 7.000131428000 & 6.297183921000 \\
\hline $11 \mathrm{C}$ & 10.807435710000 & 5.795962023000 & 2.889803973000 & $11 \mathrm{~N}$ & 10.854450240000 & 5.931849862000 & 2.992004493000 \\
\hline $12 \mathrm{C}$ & 8.097369042000 & 5.353732434000 & 4.879621534000 & $12 \mathrm{~N}$ & 8.137882219000 & 5.442700379000 & 4.871857108000 \\
\hline $13 \mathrm{C}$ & 8.390960971000 & 8.090877375000 & 6.850029332000 & $13 \mathrm{~N}$ & 8.528716680000 & 8.113596097000 & 6.782748913000 \\
\hline $14 \mathrm{C}$ & 11.156560210000 & 11.510196960000 & 2.547820917000 & $14 \mathrm{C}$ & 11.102976450000 & 11.528242630000 & 2.501541327000 \\
\hline $15 \mathrm{H}$ & 11.321854510000 & 11.856256010000 & 3.579540233000 & $15 \mathrm{H}$ & 11.262164960000 & 11.897302420000 & 3.526398342000 \\
\hline $16 \mathrm{H}$ & 10.269855090000 & 12.032964350000 & 2.158578604000 & $16 \mathrm{H}$ & 10.210702440000 & 12.031940060000 & 2.100040008000 \\
\hline $17 \mathrm{H}$ & 12.023006190000 & 11.820893680000 & 1.941170055000 & $17 \mathrm{H}$ & 11.966411010000 & 11.837252440000 & 1.889545146000 \\
\hline $18 \mathrm{C}$ & 10.796850540000 & 9.113063843000 & 0.668807494400 & $18 \mathrm{C}$ & 10.781474150000 & 9.087304768000 & 0.675172979800 \\
\hline $19 \mathrm{H}$ & 11.686241540000 & 9.434213457000 & 0.102377867600 & $19 \mathrm{H}$ & 11.662098690000 & 9.415333184000 & 0.098783835570 \\
\hline $20 \mathrm{H}$ & 9.909441615000 & 9.552173285000 & 0.191800652100 & $20 \mathrm{H}$ & 9.882986827000 & 9.499365523000 & 0.194374580300 \\
\hline $21 \mathrm{H}$ & 10.721291690000 & 8.016954084000 & 0.602195839300 & $21 \mathrm{H}$ & 10.728683090000 & 7.988897898000 & 0.627685684000 \\
\hline $22 \mathrm{C}$ & 12.618754700000 & 8.899621241000 & 3.058562736000 & $22 \mathrm{C}$ & 12.618444970000 & 8.970259121000 & 3.063247584000 \\
\hline $23 \mathrm{H}$ & 12.868821190000 & 9.143138645000 & 4.099905597000 & $23 \mathrm{H}$ & 12.875558300000 & 9.271652427000 & 4.087567238000 \\
\hline $24 \mathrm{H}$ & 13.414148210000 & 9.319047162000 & 2.419264235000 & $24 \mathrm{H}$ & 13.395913820000 & 9.375134952000 & 2.393506058000 \\
\hline $25 \mathrm{H}$ & 12.648944940000 & 7.805828710000 & 2.947466775000 & $25 \mathrm{H}$ & 12.668887740000 & 7.873781126000 & 3.008022436000 \\
\hline $26 \mathrm{C}$ & 7.569831394000 & 10.349232980000 & 1.603464137000 & $26 \mathrm{C}$ & 7.541747195000 & 10.311602390000 & 1.599751525000 \\
\hline $27 \mathrm{H}$ & 8.232764536000 & 11.142514580000 & 1.228274513000 & $27 \mathrm{H}$ & 8.205359953000 & 11.087536390000 & 1.190685345000 \\
\hline
\end{tabular}




\begin{tabular}{|c|c|c|c|c|c|c|c|}
\hline $28 \mathrm{H}$ & 6.545168059000 & 10.755795940000 & 1.630122695000 & $28 \mathrm{H}$ & 6.519971954000 & 10.725850710000 & 1.624797498000 \\
\hline $29 \mathrm{H}$ & 7.584696360000 & 9.521146991000 & 0.879301630700 & $29 \mathrm{H}$ & 7.542984265000 & 9.459664547000 & 0.903226453100 \\
\hline $30 \mathrm{c}$ & 7.824106005000 & 11.224285040000 & 4.515713632000 & $30 \mathrm{C}$ & 7.835609010000 & 11.274251590000 & 4.481402260000 \\
\hline $31 \mathrm{H}$ & 7.932835100000 & 10.894159630000 & 5.559728546000 & $31 \mathrm{H}$ & 7.989206692000 & 10.980507830000 & 5.530782211000 \\
\hline $32 \mathrm{H}$ & 6.826107936000 & 11.677831440000 & 4.399491180000 & $32 \mathrm{H}$ & 6.827491984000 & 11.710322140000 & 4.387553937000 \\
\hline $33 \mathrm{H}$ & 8.581555429000 & 11.998412780000 & 4.320966885000 & $33 \mathrm{H}$ & 8.573377044000 & 12.052054390000 & 4.233167325000 \\
\hline $34 \mathrm{C}$ & 6.704853218000 & 8.473113322000 & 3.793767663000 & $34 \mathrm{C}$ & 6.685294763000 & 8.517177212000 & 3.855162484000 \\
\hline $35 \mathrm{H}$ & 6.700526859000 & 7.621160798000 & 3.098095492000 & $35 \mathrm{H}$ & 6.683069802000 & 7.626676884000 & 3.209684705000 \\
\hline $36 \mathrm{H}$ & 5.719701015000 & 8.967642925000 & 3.737456853000 & $36 \mathrm{H}$ & 5.705122204000 & 9.014850693000 & 3.752719475000 \\
\hline $37 \mathrm{H}$ & 6.803742732000 & 8.074337395000 & 4.814830887000 & $37 \mathrm{H}$ & 6.768679318000 & 8.177727717000 & 4.897674540000 \\
\hline $38 \mathrm{C}$ & 14.121063860000 & 8.639495064000 & 7.234647676000 & $38 \mathrm{C}$ & 14.139988220000 & 8.573844787000 & 7.256742311000 \\
\hline $39 \mathrm{H}$ & 14.679406270000 & 7.772739842000 & 7.619014347000 & $39 \mathrm{H}$ & 14.682165470000 & 7.699198372000 & 7.647096312000 \\
\hline $40 \mathrm{H}$ & 14.396320780000 & 9.514210584000 & 7.846421117000 & $40 \mathrm{H}$ & 14.422288250000 & 9.445228802000 & 7.870292046000 \\
\hline $41 \mathrm{H}$ & 14.460589530000 & 8.824260407000 & 6.204017177000 & $41 \mathrm{H}$ & 14.490695500000 & 8.752769732000 & 6.228607586000 \\
\hline $42 C$ & 11.740563050000 & 8.176057727000 & 9.109753982000 & $42 \mathrm{C}$ & 11.734490730000 & 8.139079807000 & 9.107705630000 \\
\hline $43 \mathrm{H}$ & 10.648168810000 & 8.060796859000 & 9.178300743000 & $43 \mathrm{H}$ & 10.640349510000 & 8.034714691000 & 9.165925848000 \\
\hline $44 \mathrm{H}$ & 12.028166500000 & 9.075723073000 & 9.678559598000 & $44 \mathrm{H}$ & 12.027031470000 & 9.031476235000 & 9.684962299000 \\
\hline $45 \mathrm{H}$ & 12.213226360000 & 7.304547605000 & 9.584255895000 & $45 \mathrm{H}$ & 12.192748990000 & 7.259087069000 & 9.580818062000 \\
\hline $46 \mathrm{C}$ & 11.450644200000 & 9.993824705000 & 6.726508507000 & $46 \mathrm{C}$ & 11.510045860000 & 9.986303674000 & 6.739961043000 \\
\hline $47 \mathrm{H}$ & 11.687479420000 & 10.260711270000 & 5.688026858000 & $47 \mathrm{H}$ & 11.762936720000 & 10.257399810000 & 5.706088315000 \\
\hline $48 \mathrm{H}$ & 11.831168040000 & 10.803985440000 & 7.371392935000 & $48 \mathrm{H}$ & 11.908594520000 & 10.777627620000 & 7.397647243000 \\
\hline $49 \mathrm{H}$ & 10.356095570000 & 9.975771427000 & 6.832632480000 & $49 \mathrm{H}$ & 10.414773520000 & 9.992702357000 & 6.834730331000 \\
\hline $50 \mathrm{C}$ & 13.977531990000 & 5.311181608000 & 5.249440837000 & $50 \mathrm{C}$ & 13.993241080000 & 5.291748616000 & 5.272193400000 \\
\hline $51 \mathrm{H}$ & 13.647829650000 & 5.408036102000 & 4.204157009000 & $51 \mathrm{H}$ & 13.689165080000 & 5.429359229000 & 4.223685762000 \\
\hline $52 \mathrm{H}$ & 14.474233770000 & 4.333952380000 & 5.365369273000 & $52 \mathrm{H}$ & 14.467526670000 & 4.301069969000 & 5.366623526000 \\
\hline $53 \mathrm{H}$ & 14.716508560000 & 6.101250515000 & 5.449872917000 & $53 \mathrm{H}$ & 14.742793630000 & 6.060058122000 & 5.514707855000 \\
\hline $54 \mathrm{C}$ & 11.273760840000 & 4.074119125000 & 5.951701317000 & $54 \mathrm{C}$ & 11.276488730000 & 4.050321723000 & 5.905510802000 \\
\hline $55 \mathrm{H}$ & 10.415578450000 & 4.033928139000 & 6.638443202000 & $55 \mathrm{H}$ & 10.386443170000 & 4.022861361000 & 6.551188219000 \\
\hline $56 \mathrm{H}$ & 11.806434540000 & 3.109262203000 & 6.011425286000 & $56 \mathrm{H}$ & 11.801447890000 & 3.084538790000 & 6.006467010000 \\
\hline $57 \mathrm{H}$ & 10.881816120000 & 4.160651862000 & 4.926805078000 & $57 \mathrm{H}$ & 10.936148300000 & 4.126275913000 & 4.862744975000 \\
\hline $58 \mathrm{C}$ & 13.104919820000 & 5.003287922000 & 8.156773298000 & $58 \mathrm{C}$ & 13.056212950000 & 4.955213977000 & 8.155970984000 \\
\hline $59 \mathrm{H}$ & 13.870669040000 & 5.695935818000 & 8.535933949000 & $59 \mathrm{H}$ & 13.815236540000 & 5.640338286000 & 8.561237159000 \\
\hline $60 \mathrm{H}$ & 13.551806560000 & 3.995636034000 & 8.128333279000 & $60 \mathrm{H}$ & 13.500130010000 & 3.946311949000 & 8.124329999000 \\
\hline $61 \mathrm{H}$ & 12.275455440000 & 4.984009659000 & 8.879302002000 & $61 \mathrm{H}$ & 12.210517010000 & 4.929772629000 & 8.859467086000 \\
\hline${ }_{1 \mathrm{U}}[\mathrm{U}(\mathrm{I}$ & $\begin{array}{l}\left.\text { IV)N* }{ }_{2} \mathbf{C N}_{3}\right]^{1-} \\
10.034757000000\end{array}$ & 7.375728000000 & 4.883747000000 & {$\left[\begin{array}{ll}\mathrm{U} \\
\mathrm{U}\end{array}\right.$} & $\begin{array}{l}\left.\text { IV)N }{ }_{2}{ }_{2} \mathbf{N C}_{3}\right]^{1-} \\
10.129239000000\end{array}$ & 7.415174000000 & 4.858136000000 \\
\hline $2 \mathrm{Si}$ & 10.988535000000 & 9.659384000000 & 2.507023000000 & $2 \mathrm{Si}$ & 10.843132000000 & 9.658875000000 & 2.448480000000 \\
\hline $3 \mathrm{Si}$ & 8.009379000000 & 9.738781000000 & 3.370051000000 & $3 \mathrm{Si}$ & 7.899819000000 & 9.754898000000 & 3.387831000000 \\
\hline $4 \mathrm{Si}$ & 12.302155000000 & 8.389186000000 & 7.255806000000 & $4 \mathrm{Si}$ & 12.374722000000 & 8.341086000000 & 7.246608000000 \\
\hline $5 \mathrm{Si}$ & 12.448598000000 & 5.412881000000 & 6.397459000000 & $5 \mathrm{Si}$ & 12.506271000000 & 5.360874000000 & 6.440021000000 \\
\hline $6 \mathrm{~N}$ & 11.091554000000 & 5.287196000000 & 1.971327000000 & $6 \mathrm{C}$ & 11.220797000000 & 5.353626000000 & 2.096381000000 \\
\hline $7 \mathrm{~N}$ & 7.462411000000 & 4.743698000000 & 4.915227000000 & $7 c$ & 7.576979000000 & 4.927480000000 & 5.074283000000 \\
\hline $8 \mathrm{~N}$ & 7.929479000000 & 8.412284000000 & 7.792674000000 & $8 \mathrm{C}$ & 8.184567000000 & 8.699944000000 & 7.606587000000 \\
\hline $9 \mathrm{~N}$ & 9.649742000000 & 9.050171000000 & 3.512916000000 & $9 \mathrm{~N}$ & 9.531602000000 & 9.047924000000 & 3.477664000000 \\
\hline $10 \mathrm{~N}$ & 11.722496000000 & 7.036682000000 & 6.250258000000 & $10 \mathrm{~N}$ & 11.792882000000 & 6.981742000000 & 6.262061000000 \\
\hline $11 \mathrm{C}$ & 10.777231000000 & 5.914599000000 & 2.914040000000 & $11 \mathrm{~N}$ & 10.891767000000 & 6.026501000000 & 3.011230000000 \\
\hline $12 \mathrm{C}$ & 8.283725000000 & 5.585856000000 & 4.905267000000 & $12 \mathrm{~N}$ & 8.428758000000 & 5.732048000000 & 4.915072000000 \\
\hline $13 \mathrm{C}$ & 8.567050000000 & 8.109714000000 & 6.852838000000 & $13 \mathrm{~N}$ & 8.822177000000 & 8.332762000000 & 6.680940000000 \\
\hline $14 \mathrm{C}$ & 11.093493000000 & 11.538284000000 & 2.630639000000 & $14 \mathrm{C}$ & 10.989414000000 & 11.540756000000 & 2.546751000000 \\
\hline $15 \mathrm{H}$ & 11.236627000000 & 11.868908000000 & 3.672134000000 & $15 \mathrm{H}$ & 11.147549000000 & 11.875906000000 & 3.582360000000 \\
\hline $16 \mathrm{H}$ & 10.191006000000 & 12.036527000000 & 2.242340000000 & $16 \mathrm{H}$ & 10.098128000000 & 12.052747000000 & 2.156175000000 \\
\hline $17 \mathrm{H}$ & 11.953355000000 & 11.897872000000 & 2.038966000000 & $17 \mathrm{H}$ & 11.852063000000 & 11.874645000000 & 1.947947000000 \\
\hline $18 \mathrm{C}$ & 10.817372000000 & 9.129265000000 & 0.707444000000 & $18 \mathrm{C}$ & 10.657508000000 & 9.121613000000 & 0.650087000000 \\
\hline $19 \mathrm{H}$ & 11.703215000000 & 9.466679000000 & 0.141809000000 & $19 \mathrm{H}$ & 11.548163000000 & 9.423724000000 & 0.076541000000 \\
\hline $20 \mathrm{H}$ & 9.924346000000 & 9.548996000000 & 0.221343000000 & $20 \mathrm{H}$ & 9.778301000000 & 9.569010000000 & 0.166646000000 \\
\hline $21 \mathrm{H}$ & 10.770227000000 & 8.030190000000 & 0.637321000000 & $21 \mathrm{H}$ & 10.567176000000 & 8.027366000000 & 0.585947000000 \\
\hline $22 \mathrm{C}$ & 12.650534000000 & 8.955986000000 & 3.105524000000 & $22 \mathrm{C}$ & 12.493747000000 & 8.946481000000 & 3.060305000000 \\
\hline $23 \mathrm{H}$ & 12.897090000000 & 9.184575000000 & 4.151835000000 & $23 \mathrm{H}$ & 12.775142000000 & 9.254450000000 & 4.076161000000 \\
\hline $24 \mathrm{H}$ & 13.432540000000 & 9.422028000000 & 2.478786000000 & $24 \mathrm{H}$ & 13.271643000000 & 9.352750000000 & 2.391902000000 \\
\hline $25 \mathrm{H}$ & 12.724778000000 & 7.867361000000 & 2.957967000000 & $25 \mathrm{H}$ & 12.569414000000 & 7.852276000000 & 2.981400000000 \\
\hline $26 \mathrm{C}$ & 7.587660000000 & 10.237461000000 & 1.597846000000 & $26 \mathrm{C}$ & 7.438903000000 & 10.268629000000 & 1.625048000000 \\
\hline $27 \mathrm{H}$ & 8.238868000000 & 11.029580000000 & 1.196689000000 & $27 \mathrm{H}$ & 8.085428000000 & 11.056715000000 & 1.213897000000 \\
\hline $28 \mathrm{H}$ & 6.552381000000 & 10.622741000000 & 1.587049000000 & $28 \mathrm{H}$ & 6.409634000000 & 10.663744000000 & 1.639907000000 \\
\hline $29 \mathrm{H}$ & 7.630879000000 & 9.376233000000 & 0.912530000000 & $29 \mathrm{H}$ & 7.455475000000 & 9.412193000000 & 0.935352000000 \\
\hline $30 \mathrm{c}$ & 7.844169000000 & 11.248980000000 & 4.491556000000 & $30 \mathrm{C}$ & 7.779362000000 & 11.272691000000 & 4.505365000000 \\
\hline $31 \mathrm{H}$ & 7.956883000000 & 10.959398000000 & 5.548544000000 & $31 \mathrm{H}$ & 7.962165000000 & 10.997586000000 & 5.554428000000 \\
\hline $32 \mathrm{H}$ & 6.845899000000 & 11.703775000000 & 4.369695000000 & $32 \mathrm{H}$ & 6.772028000000 & 11.714485000000 & 4.440975000000 \\
\hline $33 \mathrm{H}$ & 8.598914000000 & 12.017451000000 & 4.262044000000 & $33 \mathrm{H}$ & 8.506025000000 & 12.048156000000 & 4.222205000000 \\
\hline $34 \mathrm{C}$ & 6.735383000000 & 8.441352000000 & 3.890628000000 & $34 \mathrm{C}$ & 6.611827000000 & 8.488458000000 & 3.929384000000 \\
\hline $35 \mathrm{H}$ & 6.760498000000 & 7.536231000000 & 3.264821000000 & $35 \mathrm{H}$ & 6.611614000000 & 7.600943000000 & 3.280620000000 \\
\hline
\end{tabular}




\section{ACCEPTED MANUSCRIPT}

\begin{tabular}{|c|c|c|c|c|c|c|c|}
\hline $36 \mathrm{H}$ & 5.735429000000 & 8.897216000000 & 3.776096000000 & $36 \mathrm{H}$ & 5.616761000000 & 8.958020000000 & 3.857822000000 \\
\hline $37 \mathrm{H}$ & 6.815837000000 & 8.127469000000 & 4.942958000000 & $37 \mathrm{H}$ & 6.746153000000 & 8.155298000000 & 4.967082000000 \\
\hline $38 \mathrm{C}$ & 14.180391000000 & 8.523966000000 & 7.150696000000 & $38 \mathrm{C}$ & 14.261309000000 & 8.471087000000 & 7.222738000000 \\
\hline $39 \mathrm{H}$ & 14.690956000000 & 7.632656000000 & 7.548497000000 & $39 \mathrm{H}$ & 14.753942000000 & 7.608722000000 & 7.694941000000 \\
\hline $40 \mathrm{H}$ & 14.518570000000 & 9.393094000000 & 7.741487000000 & $40 \mathrm{H}$ & 14.569269000000 & 9.372548000000 & 7.776889000000 \\
\hline $41 \mathrm{H}$ & 14.519304000000 & 8.668474000000 & 6.112018000000 & $41 \mathrm{H}$ & 14.643110000000 & 8.562641000000 & 6.194977000000 \\
\hline $42 \mathrm{C}$ & 11.756527000000 & 8.214771000000 & 9.050334000000 & $42 \mathrm{C}$ & 11.777951000000 & 8.225471000000 & 9.031385000000 \\
\hline $43 \mathrm{H}$ & 10.657027000000 & 8.164120000000 & 9.110883000000 & $43 \mathrm{H}$ & 10.679924000000 & 8.179799000000 & 9.068654000000 \\
\hline $44 \mathrm{H}$ & 12.087217000000 & 9.100273000000 & 9.620420000000 & $44 \mathrm{H}$ & 12.101539000000 & 9.117889000000 & 9.590201000000 \\
\hline $45 \mathrm{H}$ & 12.174526000000 & 7.321838000000 & 9.538121000000 & $45 \mathrm{H}$ & 12.178428000000 & 7.342127000000 & 9.547007000000 \\
\hline $46 \mathrm{C}$ & 11.586487000000 & 10.039652000000 & 6.640731000000 & $46 \mathrm{C}$ & 11.731920000000 & 9.982403000000 & 6.528132000000 \\
\hline $47 \mathrm{H}$ & 11.877718000000 & 10.306283000000 & 5.614908000000 & $47 \mathrm{H}$ & 12.399876000000 & 10.389616000000 & 5.757196000000 \\
\hline $48 \mathrm{H}$ & 11.989661000000 & 10.823787000000 & 7.307347000000 & $48 \mathrm{H}$ & 11.718014000000 & 10.708814000000 & 7.357906000000 \\
\hline $49 \mathrm{H}$ & 10.489252000000 & 10.086034000000 & 6.719107000000 & $49 \mathrm{H}$ & 10.702846000000 & 9.982696000000 & 6.134531000000 \\
\hline $50 \mathrm{C}$ & 13.961485000000 & 5.280307000000 & 5.275187000000 & $50 \mathrm{C}$ & 14.040476000000 & 5.200830000000 & 5.350868000000 \\
\hline $51 \mathrm{H}$ & 13.668814000000 & 5.388484000000 & 4.218582000000 & $51 \mathrm{H}$ & 13.781200000000 & 5.342136000000 & 4.291064000000 \\
\hline $52 \mathrm{H}$ & 14.436816000000 & 4.291352000000 & 5.395031000000 & $52 \mathrm{H}$ & 14.483238000000 & 4.197943000000 & 5.460440000000 \\
\hline $53 \mathrm{H}$ & 14.714384000000 & 6.050404000000 & 5.505226000000 & $53 \mathrm{H}$ & 14.810024000000 & 5.940679000000 & 5.615543000000 \\
\hline $54 \mathrm{C}$ & 11.184180000000 & 4.104054000000 & 5.882347000000 & $54 \mathrm{C}$ & 11.252170000000 & 4.050674000000 & 5.919894000000 \\
\hline $55 \mathrm{H}$ & 10.280972000000 & 4.103329000000 & 6.511238000000 & $55 \mathrm{H}$ & 10.361211000000 & 4.052802000000 & 6.563504000000 \\
\hline $56 \mathrm{H}$ & 11.669759000000 & 3.117943000000 & 5.996019000000 & $56 \mathrm{H}$ & 11.733698000000 & 3.063739000000 & 6.017768000000 \\
\hline $57 \mathrm{H}$ & 10.864638000000 & 4.173723000000 & 4.830998000000 & $57 \mathrm{H}$ & 10.924268000000 & 4.149509000000 & 4.876240000000 \\
\hline $58 \mathrm{C}$ & 12.957259000000 & 5.008165000000 & 8.171102000000 & $58 \mathrm{C}$ & 12.983063000000 & 4.969110000000 & 8.228492000000 \\
\hline $59 \mathrm{H}$ & 13.727273000000 & 5.684086000000 & 8.574283000000 & $59 \mathrm{H}$ & 13.757675000000 & 5.636298000000 & 8.632024000000 \\
\hline $60 \mathrm{H}$ & 13.375223000000 & 3.985644000000 & 8.183449000000 & $60 \mathrm{H}$ & 13.384275000000 & 3.942745000000 & 8.261537000000 \\
\hline $61 \mathrm{H}$ & 12.093445000000 & 5.024263000000 & 8.854382000000 & $61 \mathrm{H}$ & 12.110656000000 & 5.006633000000 & 8.896714000000 \\
\hline
\end{tabular}

